\title{
Impacts of climate change on water balance components in the central Appalachian Mountains, USA
}

\author{
Brandi Anne Gaertner \\ bagaertner@mix.wvu.edu
}

Follow this and additional works at: https://researchrepository.wvu.edu/etd

Part of the Atmospheric Sciences Commons, Climate Commons, Fresh Water Studies Commons, and the Water Resource Management Commons

\section{Recommended Citation}

Gaertner, Brandi Anne, "Impacts of climate change on water balance components in the central Appalachian Mountains, USA" (2019). Graduate Theses, Dissertations, and Problem Reports. 3931. https://researchrepository.wvu.edu/etd/3931

This Dissertation is protected by copyright and/or related rights. It has been brought to you by the The Research Repository @ WVU with permission from the rights-holder(s). You are free to use this Dissertation in any way that is permitted by the copyright and related rights legislation that applies to your use. For other uses you must obtain permission from the rights-holder(s) directly, unless additional rights are indicated by a Creative Commons license in the record and/ or on the work itself. This Dissertation has been accepted for inclusion in WVU Graduate Theses, Dissertations, and Problem Reports collection by an authorized administrator of The Research Repository @ WVU. For more information, please contact researchrepository@mail.wvu.edu. 


\title{
Impacts of climate change on water balance components in the central Appalachian Mountains, USA
}

\author{
Brandi Gaertner
}

Dissertation submitted to the

Davis college of Agriculture Natural Resources and Design

at West Virginia University

in partial fulfillment of the requirements for the degree of

Doctor of Philosophy in

Department of Forestry and Natural Resources

Nicolas Zegre, Ph.D., Chair

Timothy Warner, Ph.D.

Eungul Lee, Ph.D.

Michael Strager, PhD.

Charlene Kelly, Ph.D.

Department of Forestry and Natural Resources

Morgantown, West Virginia

2019

Keywords: Climate change, Phenology, Evapotranspiration, water balance, watershed sensitivity, catchment hydrology, central Appalachians

Copyright 2019 Brandi Gaertner 


\section{ABSTRACT \\ Impacts of climate and land cover on water balance components in the central Appalachian Mountains, USA}

\section{Brandi Gaertner}

The purpose of this research is to investigate the impact of climate and land cover on water balance components including evapotranspiration and runoff in the mountainous central Appalachian region of the United States. Forests play a critical role in provisioning freshwater resources to downstream regions, but climate change has affected growing season lengths and water balance fluxes including precipitation, evapotranspiration, and runoff, leading to large fluctuations in water yield. The effects of climate warming are especially important in headwater basins that contribute drinking water resources to downstream population centers. The central Appalachian region is one such region that provides fresh water to approximately $9 \%$ of the U.S. population including downstream metropolitan areas such as Washington D.C., Pittsburgh (PA), Cincinnati $(\mathrm{OH})$, and the Mississippi River Basin. Therefore, understanding the impacts of climate change and land use change on water balance components in headwater basins in the central Appalachian Mountains is critical for developing policies and practices that enhance future water sustainability.

In order to develop a comprehensive understanding of climate and land cover on water balance components within the central Appalachian region, the research was divided into three parts. The first study analyzed trends in climatologic, hydrologic, and growing season length variables, identified the important variables effecting growing season length changes, and evaluated the influence of a lengthened growing season on increasing evapotranspiration trends. Three growing season length variables were generated using remotely sensed GIMMS NDVI3g data, two variables from measured streamflow, and 13 climate parameters from gridded datasets. Various climate, hydrology, and phenology explanatory variables were included in two applications of Principle Components Analysis to reduce dimensionality, then the final variables were utilized in two Linear Mixed Effects models to evaluate the role of climate on growing season length and evapotranspiration. The results showed that growing season length has increased, on average, by $\sim 22$ days and evapotranspiration has increased $\sim 12 \mathrm{~mm}$. The results also suggest that a suite of climatic variables including temperature, vapor pressure deficit, wind, and humidity are important in growing season length change. The climatic variables work synergistically to produce greater evaporative demand and atmospheric humidity, which is theoretically consistent with the Clausius-Clapeyron relation, which states that humidity increases nonlinearly by $7 \% / \mathrm{K}$. Optimization of the evapotranspiration model was increased by the inclusion of growing season length, suggesting that growing season length is partially responsible for variations in evapotranspiration over time. The results of this research imply that a longer growing season has the potential to increase forest water cycling and evaporative loss in temperate forests, which may lead to decreased freshwater provisioning from forests to downstream population centers. Additionally, results from this study provide important information for runoff and evapotranspiration prediction modelling and forest water management under changing climate. 
The second study quantified long-term historical and future climate trends, evaluated water balance sensitivity to change, and quantified future runoff for catchments located throughout the central Appalachian Mountains regions of the eastern USA. Long-term historical precipitation $(\mathrm{P})$, potential evapotranspiration (PET), and evapotranspiration (ET) were implemented in a Budyko-based sensitivity hydrologic model to determine watershed sensitivity to changing energy and water inputs. Long-term future streamflow was modeled based on derived sensitivity coefficients and future PET and P. The results showed that streamflow sensitivity increased with decreasing precipitation throughout the region. Future runoff is projected to increase between 9$17 \%$ throughout the region, with runoff increasing with increasing precipitation quantity. The sensitivity was lowest in regions with highest precipitation, which generally followed the rain shadow pattern, with the lowest sensitivity along the Appalachian mountain spine and increasing sensitivity with increasing distance from the mountains. The sensitivity coefficients throughout the regions were also controlled by other climate and landscape characteristics including forest cover, precipitation inputs, and soil moisture holding capacity. Watershed sensitivity and future increasing $\mathrm{P}$ is expected to result in increasing runoff, which has important implications for infrastructure, energy, and ecosystem service supply. We discuss preventative forest management measures to minimize future water resource concerns and maintain stable drinking water supplies to downstream communities.

The third study examined the regional and local spatial relationships between climate variables and evapotranspiration trends throughout the central Appalachian region. Regional and local $\left(4 \mathrm{~km}^{2}\right)$ scale drivers of evapotranspiration including temperature, precipitation, dew point temperature, and vapor pressure deficit were determined using an ordinary least squares and geographically weighted regression model. Across the central Appalachian region, vapor pressure deficit, precipitation and temperature were found to have the most significant relationship with ET. At the $4 \mathrm{~km}^{2}$ scale, vapor pressure deficit was found to have the strongest relationship. The relationship between ET, precipitation, and temperature underscores the importance of evaporative atmospheric demand (temperature) and water input (precipitation) required for the evapotranspiration processes. ET at the local scale is largely driven by competing forces that are increasing ET such as a longer growing season and higher vapor pressure deficit, and biological processes that decrease ET such as water use efficiency and drought stress mechanisms. ET trends did not significantly change throughout the region, suggesting that there are even more complicated competing factors. Understanding the underlying biological and physical ET processes provides insight into future water resources. 


\section{Dedication}

For my husband, who supported me always

For my family, who is unendingly proud of me.

Thank you for your love and support. 


\section{Acknowledgements}

Completing this $\mathrm{PhD}$ has been a lifetime achievement and has been both one of the most impressive and difficult tasks I have completed in my lifetime. Throughout the process I have grown from a college student to a seasoned scientist. This dissertation stands as a scientific product of not only my tenure at WVU in the doctoral program but also as a trophy for a lifelong dream attained. I have many people to thank for helping me throughout the five-year process.

First of all, I would like to thank my advisor Dr. Nicolas Zegre. I absolutely could not have completed this dissertation without his help, revisions, and insight. When I first entered the program, I did not have a background in hydrology nor very well formulated writing skills. Dr. Zegre helped me (in a large part through trial and error) hone my writing skills, learn to think like a scientist, connect big picture problems, and ask important scientific questions. Throughout all personal and professional hurtles, Zegre always maintained an open communication policy and was always available to answer any and all questions. Most importantly, under Zegre's tutelage, I have learned how to maintain a fuzzy line between work and play life, which allowed me to combine my passion for the outdoors (mountain biking, cross country skiing, caving, etc) and my interest in hydrologic sciences. Finally, I know that my professional relationship with Zegre will not end here and that he will be open to answering any future questions I have about my professorship at Alderson Broaddus, about hydrology, or about the outdoors. I have a life mentor. Thank you.

I would like to thank my committee members for helping me throughout my writing progression and the doctoral process. Dr. Timothy warner has provided countless revisions on all three of the chapters of the dissertation, but ultimately helped publish the first chapter. All committee members have contributed in the important milestones of the proposal and the comprehensive exams. While both are stressful, exhausting, and (at the end) exhilarating, my committee members made me feel comfortable, kept the atmosphere light, and never made it too stressful. I want to say thank you for making this happen. You have all been wonderful.

Finally, I want to express my gratitude to my family and husband. My family has always been proud of me, said it frequently, and always knew I would finish (even when I wasn't sure myself). My husband has supported me along the way, in times when I was overwhelmed and stressed out (who isn't sometimes) and when I was ecstatic. I don't know how many times he's heard "I finally finished my revisions!", or that time when I passed my comps, got my paper published, etc. He was there for everything. What a ride. 


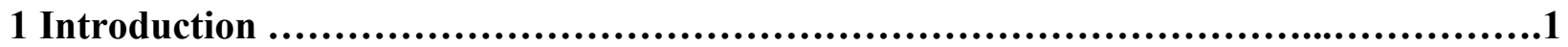

2 Climate, Forest Growing Season, and Evapotranspiration Changes in the central Appalachian Mountains, USA............................................................4

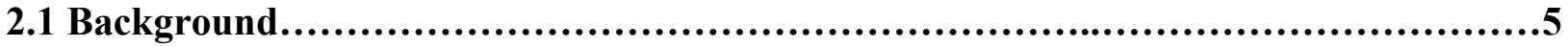

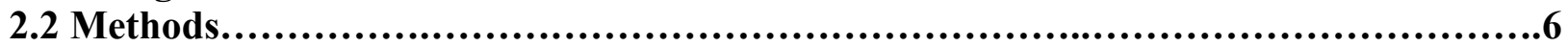

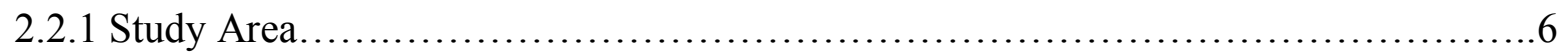

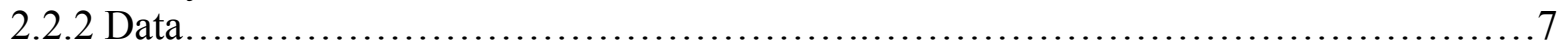

2.2.2.1 Vegetation phenology from satellite imagery. ................................

2.2.2.2 Hydrologic Variables...........................................................

2.2.2.3 Climate Variables............................................................ 9

2.2.3 Statistical Methods............................................................. 9

2.2.3.1 Quantifying trends in climate and growing season length.......................

2.2.3.2 Identifying important components of growing season length change ..............10

2.2.3.2.1 Principle Components Analysis............................................. 10

2.2.3.2.2 Mixed Effects Model...................................................... 10

2.2.4 Interaction of growing season length and evapotranspiration change..................11

2.2.4.1 Principles Component Analysis.............................................11

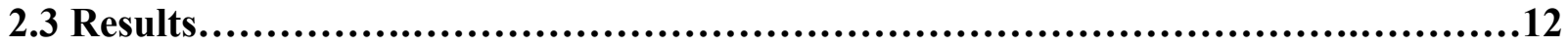

2.3.1 Question 1: How has climate and growing season length changed?.............................12

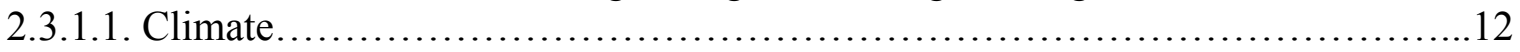

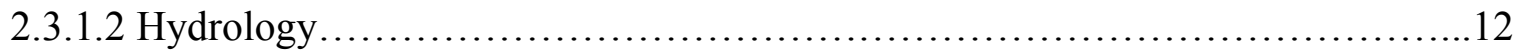

2.3.1.3 Growing season length.........................................................

2.3.2 Question 2: What are the predictors of growing season length?....................................13

2.3.3 Question 3: Does growing season length influence evapotranspiration?.......................14

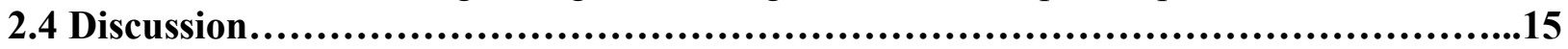

2.4.1 Question 1: How has climate and growing season length changed?.............................15

2.4.2 Question 2: What are the predictors of growing season length?...................................16

2.4.3 Question 3: Does growing season length influence evapotranspiration?.......................18

2.5 Conclusion and Future Directions.......................................................19

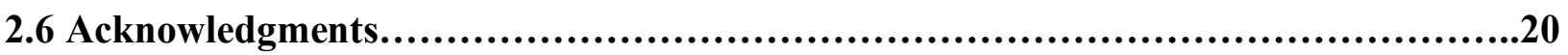

3 Spatial variations in streamflow sensitivity to climate change: Implications for water resources management in the central Appalachian Mountains region, USA.........43

3.1 Introduction..........................................................................43

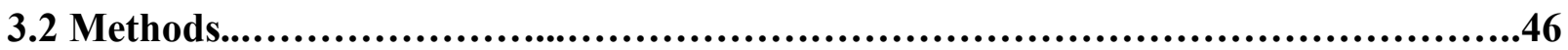

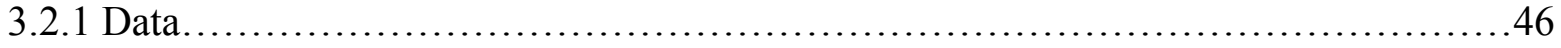

3.2.2 Quantifying climate and water balance changes....................................47

3.2.2 Quanitfying streamflow sensitivity to climate change and catchment parameters.....48

3.2.3. Modelling future streamflow sensitivity .......................................49

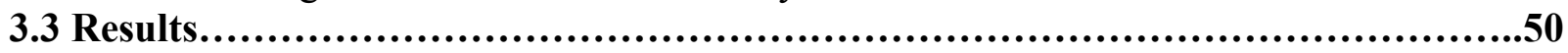

3.3.1 Climate and water balance changes in the central Appalachian Mountains region......50

3.3.1.1 Historic Climate and Water Balance.........................................50

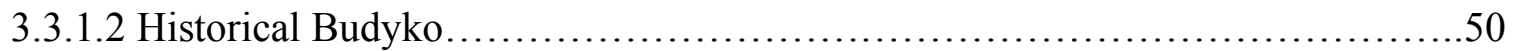


3.3.1.3 Future climate and Budyko components....................................50

3.3.2 Streamflow sensitivity to changes in climate and catchment factors ..................51

3.3.3 Modelling future $\mathrm{Q}$ using the results of the sensitivity approach....................51

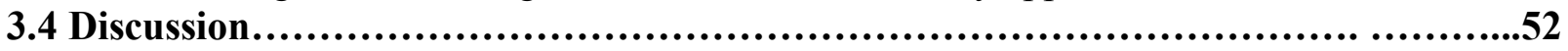

3.4.1 How has climate changed in the central Appalachian Mountains?................................52

3.4.2. How sensitive are catchment in the central Appalachian Mountains region to climate

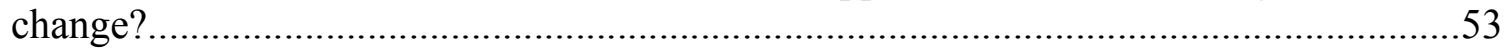

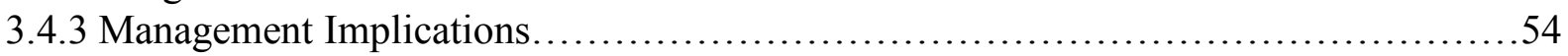

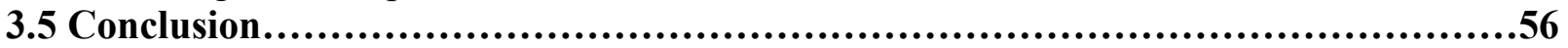

4 Spatial Evapotranspiration trends and drivers across the central Appalachian Mountains, United States..........................................................80

4.1 Introduction .........................................................................80

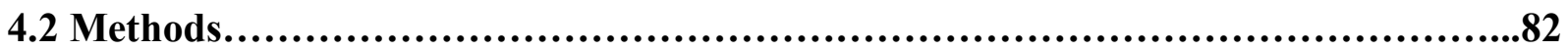

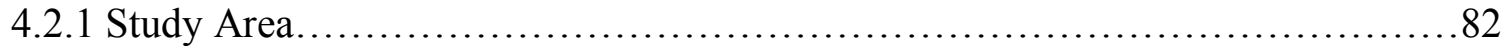

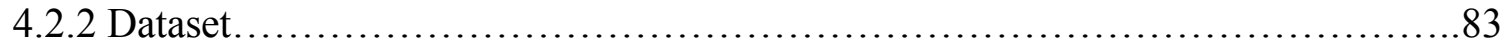

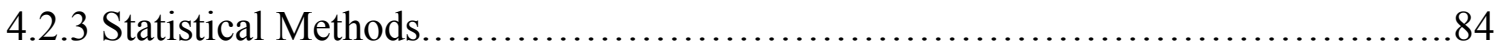

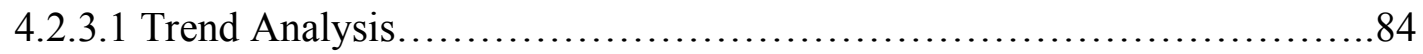

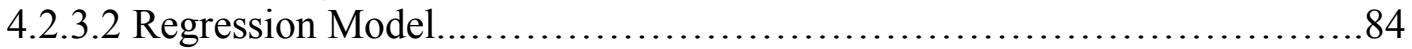

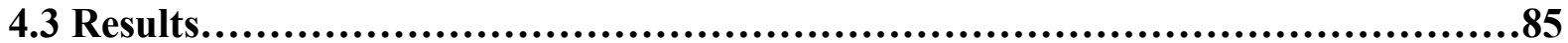

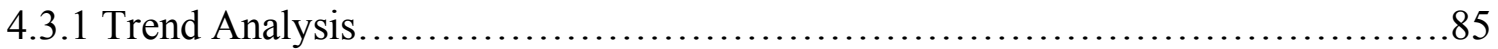

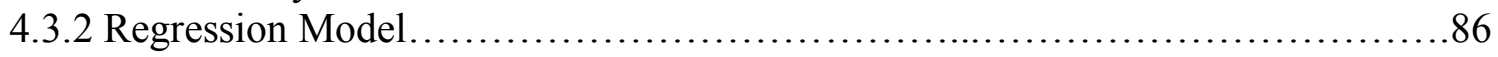

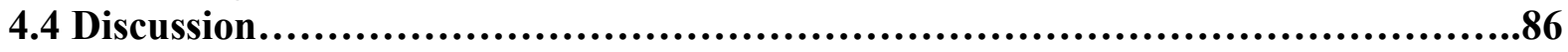

4.4.1. Changes in regional climate and water balance components....................86

4.4.2 Regional and local Evapotranspiration drivers............................. 88

4.4.3 Implications of climate change on evapotranspiration..........................89

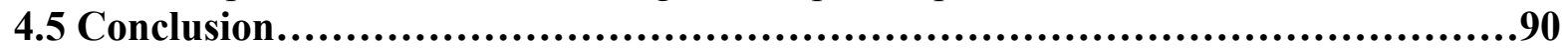

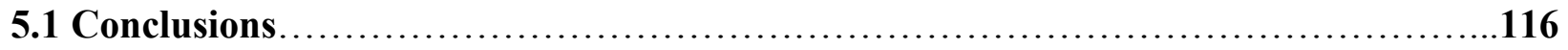




\section{List of Tables}

Table 2.1 Summary table for all variables and acronyms.................................

Table 2.2 Mann Kendal trend table and total change over 31 years for the 31 watersheds in the central Appalachian region. Watershed Identifiers represents each watershed within the five basins, shown in Figure 1. Station number and station name refer to USGS stream gauge identifiers. Bold represents significance at the 0.05 level and bold+italics represents significance at the 0.01 level.

Table 2.S.1 Table of the $31 \mathrm{HCDN}$ watersheds used to study climate and growing season changes in the central Appalachian Region. Study watershed identifiers uniquely classify USGS gauging stations used in this study and corresponds to the Identifier in Figure 1. Station number and station name refer to USGS stream gauge identifiers, and area refers to area upstream of the USGS gauge.....

Table 2.S.2 Climate, hydrology, and phenological datasets used in this study..................37

Table 2.S.3: Mann Kendal trend table and total change over 31 years for the 31 watersheds in the central Appalachian region. Watershed Identifiers represents each watershed within the five basins, shown in Figure 1. Station number and station name refer to USGS stream gauge identifiers. Bold represents significance at the 0.05 level and bold + italics represents significance at the 0.01 level.

Table 2.S.4 Factor loadings for the Principle Component Analysis used to reduce dimensionality of growing season length variables. Growing season length related variables with Eigen vectors $>1$ and factor loadings significantly contributing (i.e. factor loadings rounding to $\geq|0.4|)$ are shown.

Table 2.S.5 Best supported mixed effects model parameter estimates based on PCA for identifying important climatic variables effecting mean annual growing season change over the 31 watersheds evaluated in this study.

Table 2.S.6 Factor Loadings for the Principle Component Analysis used to reduce dimensionality of evapotranspiration variables. Evapotranspiration related variables with Eigen vectors $>1$ and factor loadings significantly contributing (i.e. factor loadings rounding to $\geq|0.4|)$ are shown...............................................41

Table 2.S.7 Best supported mixed effects model parameter estimates based on PCA for identifying the interaction of growing season length and mean annual evapotranspiration over the 31 watersheds evaluated in this study.

Table 3.1 Long-term historic (1965-2015) average annual climate and water balance components in $\mathrm{mm} /$ year (potential evapotranspiration [PET], precipitation [P], streamflow [Q], evapotranspiration $[\mathrm{AET}]$, dryness index $[\mathrm{PET} / \mathrm{P}]$, and evaporative index $[\mathrm{ET} / \mathrm{P}]$ ) for catchment located in the central Appalachian Mountains region, USA. The $n$ value is a catchment specific parameter that incorporates watershed characteristics, is calculated using the Budyko framework following the Choudhury (1999) framework.

Table 3.2: Mann-Kendall trend analysis for PET, P, and ET for the 31 study watershed from 1965-2015. Denotes the total change over the study period based on the Sen slope value. All values are represented as in percentage change from the annual historic streamflow amount (Table 1). * represents significance at alpha $=0.05$ and $* *$ represent significance at

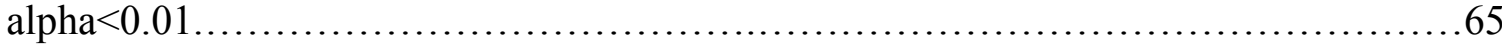


Table 3.3 Future PET and $P$ in mm and dryness index (PET/P) for each catchment from 20152099 based on future ensemble climate data from the Multivariate Adaptive Constructed Analogs version 2 (MACAv2-METDATA) dataset (Abatzoglou and Brown 2012). The Station name corresponds to the USGS HCDN watershed output station name. $\mathrm{RCP}_{4.5}$ refers to the 4.5 emission scenario for future climate projections, while $\mathrm{RCP}_{8.5}$ refers to the 8.5 emission scenario.

Table 3.4: Relative change (\%) in PET and P between historical (1965-2015) and future (20152099) climate. $\mathrm{RCP}_{4.5}$ refers to the 4.5 emission scenario for future climate projections, while $\mathrm{RCP}_{8.5}$ refers to the 8.5 emission scenario.................................. 68

Table 3.5 Streamflow (Q) sensitivity to climate variability, where $\partial \mathrm{Q} / \partial \mathrm{P}$ indicates the $\mathrm{Q}$ sensitivity to an increase in precipitation, $\partial \mathrm{Q} / \partial \mathrm{PET}$ indicates $\mathrm{Q}$ sensitivity to an increase in Potential Evapotranspiration, and $\partial \mathrm{Q} / \partial \mathrm{n}$ indicates $\mathrm{Q}$ sensitivity to a change in watershed characteristics (e.g. land use). An increase in $\mathrm{P}$ will increase streamflow, an increase in PET and $n$ will decrease streamflow.

Table 3.6 Future streamflow change relative to historical Q in mm from 2070-2099 calculated using the Q sensitivity to P and PET (Table 3). Future streamflow was calculated under a low emissions scenario (RCP 4.5) and a high emissions scenario (RCP 8.5) for each catchment and basin (in bold).

Table 4.1 Table of the 31 HCDN watersheds used to study climate and growing season changes in the central Appalachian Region. Study watershed identifiers uniquely classify USGS gauging stations used in this study and corresponds to the Identifier in Figure 1. Station number and station name refer to USGS stream gauge identifiers, and area refers to area

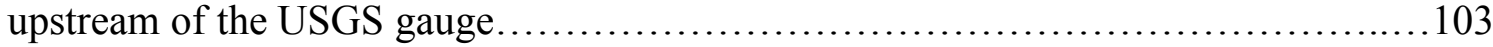

Table 4.2 Long-term historic (2000-2015) average climate and water balance components in the central Appalachian region averaged for the growing season (April to October) (Tmax; maximum temperature, Tmin [minimum temperature]; Tmean [average temperature]; $\mathrm{P}$ [Precpiation]; ET [Evapotranspiration]; DPT [Dew point temperature]; VPDmin [minimum vapor pressure deficit]; VPDmax [maximum vapor pressure deficit]........107

Table 4.3 Relative change (\%) in climate and water balance for growing season climate variables based on a Mann Kendal test for the 31 watersheds in the central Appalachian region from 2000-2013..

Table 4.4 Global correlation analysis between three climate variables (predictor variables) and evapotranspiration (response variable) based on ordinary least squares regression across the central Appalachian region. Coefficient [a] represents the direction of the regression, VIF indicates model multicollinearity, Jarque-Bera represents value clustering, $\mathrm{R}^{2}$ indicates model performance, and Moran's I indicates spatial clustering.. ............110

Table 4.5 Local correlation between six climate variables and evapotranspiration across the central Appalachian region based on a Geographically Weighted Regression (GWR)...110 


\section{List of Figures}

Figure 2.1 A. Location of the study region in the central Appalachian Mountains region of the eastern USA. B. Study Area depicting the conceptual change in growing season length from 1982 and 2012 (e.g. LOS in 2012 - LOS in 1982). Green regions represent minimal change between the two years ( $0-15$ days) while red represents maximum change (60-70 days). The dashed lines depict basin boundaries Potomac (P), Monongahela (M), Ohio $(\mathrm{O})$, Kanawha (K), and Tennessee (T). The solid lines outline the 31 watersheds, and the identifiers label the basin followed by an HCDN (Slack and Landwehr 1992) watershed number from 1 to $\mathrm{n}$

Figure 2.2 Land Cover composition depicting proportion agriculture, developed, and forest for the 31 watersheds based on 2011 NLCD land cover analysis throughout the central Appalachian region. Forests include deciduous, evergreen, and mixed forests, developed includes open space, barren land, low, medium, and high intensity development, and agriculture includes herbaceous, hay/pasture, and cultivated crops.

Figure 2.3 Figure depicting the process for extracting phenology variables from time series of NDVI data using the program TIMESAT. Gray lines represent NDVI data, the black line represents the smoothed timesat vegetation signal, the gray dots represent $50 \%$ canopy at start (SOS) and end of season (EOS), LOS represents the difference between EOS and SOS

Figure 2.4 Exponential relationship between long-term (1982-2012) annual temperature and specific humidity for 31 watersheds located in the central Appalachian Mountains region. The relationship is exponential, following the theoretical Clausius-Clapeyron relationship (Held and Soden 2006). The relationship states that atmospheric water vapor will exponentially increase with air temperature by $3.4 \%$ to $7 \% /{ }^{\circ} \mathrm{K}$ (or a slope of $2.45 \mathrm{e}^{0.06}$ ) (Held and Soden 2000), though the observed relationship has a slope $\left(\mathrm{y}=4.095 \mathrm{e}^{0.03}\right)$ closer to the lower end of the rates proposed $\left(3.4 \% /{ }^{\circ} \mathrm{K}\right.$ ) (Allen and Ingram 2002).............35

Figure 3.1 Location of the study area in the central Appalachian Mountains region of the eastern USA. The dashed lines depict basin boundaries of the five basins examined in this study: Potomac (P), Monongahela (M), Ohio (O), Kanawha (K), and Tennessee (T). The solid lines outline the $31 \mathrm{HCDN}$ watersheds, and the identifiers label the basin followed by an HCDN (Slack and Landwehr 1992) watershed number from 1 to j....................72

Figure 3.2: Conceptual figure illustrating the Budyko framework for the central Appalachian region. The dryness index represents energy limited $(\mathrm{PET} / \mathrm{P}<1)$ and water limited $(\mathrm{PET} / \mathrm{P}>1)$ basins. An energy limited basin receives greater $\mathrm{P}$ than $\mathrm{PET}$, while a water limited basins receive a higher ratio of $\mathrm{P}$ to $\mathrm{PET}$. The evaporative index $(\mathrm{E} / \mathrm{P})$ provides watershed specific climatic factors, with a high E/P representing no runoff and low representing high runoff. $n$ values curves implement catchment specific factors into the Budyko framework. High $\mathrm{n}$ factors translate to low runoff and low $\mathrm{n}$ factors generally have high runoff...

Figure 3.3 Climate and Budyko variables for the central Appalachian Mountain region from 1965-2015. A. Annual precipitation (mm) B. Average annual potential evapotranspiration $(\mathrm{mm}) \mathrm{C}$. Annual evaporative index D. Annual dryness index..........................74 
Figure 3.4 Average annual precipitation for the five basins located in the central Appalachian region showing that streamflow sensitivity increases with decreasing precipitation.......75

Figure 3.5 Relationship between the evapotranspiration ratio and dryness index of our basins for the period 1965-2015. Each identifier number refers to the watersheds depicted in figure 1. All catchments were considered to be energy limited and $n$ values range from 0.3 to

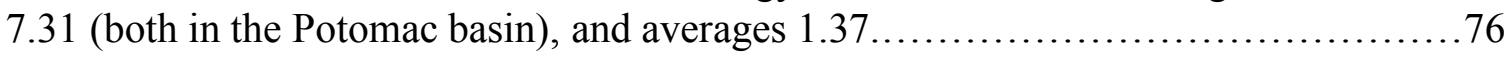

Figure 3.6 Slope of the central Appalachian Mountains, with blue representing steep slopes (close to vertical) and red representing low slope.

Figure 4.1 Location of the study basin and catchments in the central Appalachian Mountains region of the eastern USA. The dashed lines depict basin boundaries Potomac (P), Monongahela (M), Ohio (O), Kanawha (K), and Tennessee (T). The solid lines outline the 31 watersheds, and the identifiers label the basin followed by an HCDN (Slack and Landwehr 1992) watershed number from 1 to $\mathrm{j}$...

Figure 4.2: Map of climate variables in the central Appalachian region. A. Maximum Temperature $\left({ }^{\circ} \mathrm{C}\right)$, B. Precipitation $(\mathrm{mm})$, C. Maximum Vapor Pressure Deficit $(\mathrm{hPa}), \mathrm{D}$.

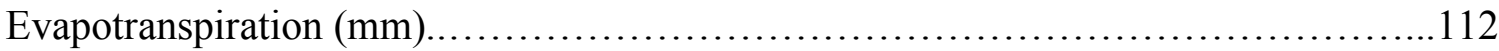

Figure 4.3 Standard residuals between minimum temperature, minimum vapor pressure deficit, precipitation and evapotranspiration. Residuals show clustering in the Potomac and Monongahela basins

Figure 4.4 Local $\left(4 \mathrm{~km}^{2}\right)$ spatial regression between maximum vapor pressure deficit and evapotranspiration across the central Appalachian region using a Geographically Weighted Regression.

Figure 4.5. Smoothed time series of annual evapotranspiration from 2000-2013 using a LOESS (locally weighted scatter-plot smoother) curve. Blue line denotes the time series while the gray shaded area represents a 95\% confidence boundary. The low value in 2008 represents an extreme (D3) drought. 
List of Abbreviations

\begin{tabular}{ll}
\hline Variable & Acronym \\
\hline \hline Precipitation & $\mathrm{P}$ \\
Evapotranspiration & $\mathrm{ET}$ \\
Specific humidity & $\mathrm{sph}$ \\
Average annual maximum temperature & tmax \\
Average annual minimum temperature & tmin \\
Average annual maximum humidity & $\mathrm{rmax}$ \\
Average annual minimum relative humidity & $\mathrm{rmin}$ \\
Solar radiation & srad \\
Dew point temperature & DPT \\
Potential evapotranspiration & PET \\
Wind direction & th \\
Wind speed & vs \\
Maximum vapor pressure deficit & vpdmax \\
Minimum vapor pressure deficit & vpdmin \\
Runoff & $\mathrm{Q}$ \\
Start of season & SOS \\
End of season & EOS \\
Length of season & LOS \\
Normalized Difference Vegetation Different & NDVI \\
\hline
\end{tabular}




\section{Introduction}

Forested headwater catchments play a critical role in freshwater provisioning, but climate change has affected the landscape and water balance components responsible for this water yield (DeWalle et al. 2000, Post and Jones 2001, Creed et al. 2014). Higher air temperatures have increased evapotranspiration rates (Huntington 2006) through higher atmospheric demand and longer growing season length (Schwartz et al. 2006), which has implications for the long-term water budget, overland runoff, and drinking water resources. Changing annual water yields have been observed in headwater basins throughout the United States (Campbell et al. 2011, Wang and Hejazi 2011, Jones et al. 2012), with humid regions tending to become wetter while arid regions have tended to become drier (Chou et al. 2009). The effects of climate warming on water yield from headwater basins have been of great concern given their importance in provisioning drinking water resources to downstream population centers (Viviroli and Weingartner 2004, Viviroli et al. 2007). One such headwater basin is the central Appalachian Mountains region in the eastern United States, which is responsible for providing approximately $30 \%$ of drinking water resources (Dudley and Stolton 2003) to downstream metropolitan areas such as Washington D.C., Pittsburgh (PA), Cincinnati (OH), and the Mississippi River Basin. Despite the importance of the central Appalachian region for provisioning fresh water to approximately $9 \%$ of the U.S. population, the impact of climate change on growing season length, evapotranspiration rates, and runoff sensitivity in the headwater basins of the central Appalachian region is largely unknown.

Growing season length is important for partitioning rainfall into evaporation and runoff in forests and partially controls evapotranspiration (ET), which cycles up to $62 \%$ of terrestrial water to the atmosphere (Dingman 2015). Globally, leaf development (e.g. budburst) has arrived earlier over the last 30-40 years (Chmielewski and Rötzer 2001, Schwartz et al. 2006, Lebourgeois et al. 2010), leading to a longer growing season in temperate forests (Richardson et al. 2006, Jeong et al. 2011, Creed et al. 2015). Increasing temperatures have long been identified as the primary driver of the growing season changes (Morin et al. 2010, Dragoni and Rahman 2012) but recent studies have found that temperature, alone, cannot explain phenological variation in temperate forests (Wolkovich et al. 2012, Marchin et al. 2015). The water cycle itself could potentially impact the growing season through increased humidity, which can signal spring onset and fall 
senescence in forests (Hu et al. 2011, Laube et al. 2014). However, the processes responsible for longer growing season are not completely understood, nor is the impact of the longer growing season on evapotranspiration. Therefore, understanding the underlying processes could provide insight into future water resources and water management strategies.

Streamflow from forested catchments respond to longer growing season and climate change by altering how much precipitation is partitioned to streamflow and evaporation (Campbell et al. 2011, Caldwell et al. 2012). Individual watershed characteristics such as growing season length, forest cover, soil moisture holding capacity, rainfall, and slope affect the rate of streamflow partitioning (Sankarasubramanian et al. 2001, Jones et al. 2012, Padrón et al. 2017). Watersheds that partition a large portion of rainfall to runoff are considered more sensitive to climate change than watersheds that are more able to buffer the long-term climate changes (Roderick and Farquhar 2011). Understanding watershed sensitivity is particularly important in headwater basins like the central Appalachian region that provide drinking water resources to downstream population centers. However, the watershed sensitivities of this the headwater catchment of the region are currently unknown. Understanding the watershed sensitivities also provide insight into future streamflow quantity, which is important for preparing infrastructure for a change in water resources availability. Therefore, in this project, I use the Budyko-based sensitivity hydrologic model to identify streamflow sensitivity and future streamflow quantity in the headwater basins of the Central Appalachian region, United States.

ET is important for regulating the water budget, reducing streamflow and runoff fluxes, maintaining forest and soil health, and providing ecosystem productivity. Climate change has increased ET fluxes through intensification of the water cycle due to greater energy demand (Huntington 2006). However, the underlying processes driving ET changes are not completely understood, since a higher energy demand via climate change encompasses many climatic and biophysical factors (Gaertner, 2018). Models that have implemented climatic factors to understand the partitioning of ET into runoff have found that regional-level ET responses are limited by water (precipitation) or energy (potential ET) availability and demand (Budyko 1974). Other models have identified that, at the ecosystem level, biophysical factors including growing season length impact ET fluxes (Hwang et al. 2014, Kim et al. 2018). ET trends are, therefore, a function of complex global drivers and multifaceted climatic processes, and the drivers differ at the regional and ecosystem level. Currently, despite the importance of ET in provisioning 
downstream water supply to metropolitan areas around the Central Appalachian region, ET process are not completely understood. Therefore, understanding ET trends and processes are exceedingly important for future streamflow, runoff, and water cycling predictions, as well as watershed management in the central Appalachian Mountains.

The overall objective of this dissertation is to investigate impact of climate change on growing season length, ET rates, runoff, and runoff sensitivity in the headwater basins of the central Appalachian region. Three main questions are addressed:

1. Which climate variables most strongly influence growing season length changes and how does growing season length affect ET throughout the central Appalachian region?

2. What is the streamflow sensitivity to climate change and how will streamflow change in the future?

3. What is the spatial relationship between local and regional climate and ET trends? 


\title{
2 Climate, Forest Growing Season, and Evapotranspiration Changes in the central Appalachian Mountains, USA
}

*published as Gaertner, B.A., N. Zegre, T. Warner, R. Fernandez, Y. He, and E.R. Merriam. 2018. Climate, forest growing season, and evapotranspiration changes in the central Appalachian Mountains, USA. Science of the Total Environment.

\begin{abstract}
This study analyzed trends in climatologic, hydrologic, and growing season length variables, identified the important variables effecting growing season length changes, and evaluated the influence of a lengthened growing season on increasing evapotranspiration trends for the central Appalachian Mountains region of the United States. We generated three growing season length variables using remotely sensed GIMMS NDVI3g data, two variables from measured streamflow, and 13 climate parameters from gridded datasets. We included various climate, hydrology, and phenology explanatory variables in two applications of Principle Components Analysis to reduce dimensionality, then utilized the final variables in two Linear Mixed Effects models to evaluate the role of climate on growing season length and evapotranspiration. The results showed that growing season length has increased, on average, by $\sim 22$ days and evapotranspiration has increased up to $\sim 12 \mathrm{~mm}$ throughout the region. The results also suggest that a suite of climatic variables including temperature, vapor pressure deficit, wind, and humidity are important in growing season length change. The climatic variables work synergistically to produce greater evaporative demand and atmospheric humidity, which is theoretically consistent with the Clausius-Clapeyron relation, which states that humidity increases nonlinearly by $7 \% / \mathrm{K}$. Optimization of the evapotranspiration model was increased by the inclusion of growing season length, suggesting that growing season length is partially responsible for variations in evapotranspiration over time. The results of this research imply that a longer growing season has the potential to increase forest water cycling and evaporative loss in temperate forests, which may lead to decreased freshwater provisioning from forests to downstream population centers. Additionally, results from this study provide important information for runoff and evapotranspiration prediction modelling and forest water management under changing climate.
\end{abstract}




\subsection{Background}

Forests play a critical role in provisioning freshwater resources to downstream regions (Viviroli and Weingartner 2004) but climate change has affected growing season length (Schwartz et al. 2002), having implications for the terrestrial water cycle (Hwang et al. 2014, Creed et al. 2015). Therefore, it is critical to understand how forest growing season change alters rainfall partitioning into evaporation and runoff in deciduous forests, in order to sustainably manage forested headwater watersheds as a source of freshwater. Higher air temperatures have resulted in greater fluxes of precipitation $(\mathrm{P})$ and evapotranspiration $(\mathrm{ET})$ between the terrestrial and atmospheric systems, leading to water cycle intensification (Trenberth et al. 2007, Huntington 2010). Growing season length partially controls ET, which cycles up to $62 \%$ of terrestrial water to the atmosphere (Dingman 2015). P and atmospheric evaporative demand have increased due to warmer temperatures (Trenberth et al. 2007, Huntington 2010), leading to changing annual water yields (Campbell et al. 2011, Wang and Hejazi 2011, Jones et al. 2012), with humid regions tending to become wetter while arid regions have tended to become drier (Chou et al. 2009). A longer growing season has the potential to alter water cycle fluxes through increased plant water use and ET (Hwang et al. 2014) in deciduous forests, which can potentially alter forest freshwater partitioning into streamflow (Q) and ET (Creed et al. 2015). Understanding these interactions is vital for future Q and ET projections as well as for sustainably managing headwater forests.

Intensification of the water cycle is theoretically consistent with the Clausius-Clapeyron relation (Held and Soden 2000), which states that warmer air holds more water (e.g. greater maximum specific humidity) and that consequently, atmospheric water vapor tends to increase non-linearly with increases in air temperature. A warmer climate can also increase growing season length and provide more energy for ET, potentially decreasing Q (Hwang et al. 2014). Studies have shown that over recent decades growing season has arrived earlier in general in temperate forests (Chmielewski and Rötzer 2001, Richardson et al. 2006, Schwartz et al. 2006, Lebourgeois et al. 2010, Jeong et al. 2011, Creed et al. 2015). Warmer air temperature has been identified as an important climate variable for growing season length changes (Morin et al. 2010, Dragoni and Rahman 2012) but recent studies have found that temperature (Wolkovich et al. 2012, Marchin et al. 2015) and photoperiod (Bauerle et al. 2012) alone do not explain phenological variations in temperate forests. The water cycle itself could potentially impact the 
growing season through increased rate of humidity, which have been shown to signal spring onset and fall senescence in forests (Hu et al. 2011, Laube et al. 2014).

In the densely populated eastern USA, the heavily forested mountains of central Appalachian Mountains play a critical role in freshwater provisioning, providing approximately 30\% (Caldwell et al. 2014) of water used by downstream communities (Parker et al. 1907, Caldwell et al. 2016). The central Appalachian Mountains region encompasses West Virginia (WV), parts of Virginia (VA), North Carolina (NC), Maryland (MD), and Tennessee (TN) (ARC 1970). This region is greater than $80 \%$ forested (Slayer 2014), has steep slopes, and geographic variability that includes high elevation and coastal areas. As a regional water source (Viviroli et al. 2007) for approximately $9 \%$ of the U.S. population (U.S.CensusBureau 2009), the central Appalachian Mountains region is representative of other temperate forests that provide freshwater services around the globe. Climate driven shifts in freshwater partitioning in forests could impact water supplies for major population centers downstream.

The overall objective of this paper is therefore to quantify long-term changes in climate, water balance components, and growing season length across the region to provide insight into the interactions between climate change, growing season length, and ET. We hypothesize that humidity is an important climatic variable of growing season length changes and that a lengthened growing season is in part responsible changing evapotranspiration. In testing this hypothesis, the following questions are explored:

1. How has historical climate, growing season length, and water balance components changed over time throughout the central Appalachian Mountains region?

2. What are the climatic variables important to growing season length changes in the temperate forests of the region?

3. How do changes in growing season length effect forest ET throughout the region?

\subsection{Methods}

\subsubsection{Study Area}

Our study area consists of 31 watersheds located across five dominant river basins that collectively cover $125,000 \mathrm{~km}^{2}$ in the eastern USA (Figure 1). Of the five basins, 4 (Monongahela, Upper Ohio, Kanawha, and Tennessee) drain west to the Mississippi River and Gulf of Mexico, while the Potomac River drains east to Washington D.C. and the Chesapeake 
Bay. The 31 watersheds selected for this study are part the U.S. Geological Survey HydroClimatic Data Network (HCDN) (Slack and Landwehr 1992). HCDN consists of streamflow station data for minimally impacted $(<10 \%$ human influence such as reservoirs, diversion, land use change, or severe ground-water pumping) watersheds. A regional land cover analysis using data from the 2011 National Land Cover Database (NLCD) (Homer et al. 2015) was used to verify that watersheds met the HCDN definition (Figure 2). The HCDN watersheds selected for this research cover approximately $39 \%$ of the total area in the five river basins, with seven watersheds in the Kanawha basin, five watersheds in the Monongahela basin, two watersheds in the Ohio basin, thirteen watersheds in the Potomac Basin, and four watersheds in the Tennessee basin. The forests are mostly classified as mixed mesophytic, dominated by hardwood species (e.g. Quercus (oaks), Betula (birch), Fagus (birch), Acer (maple), Populus (poplar)) located on ridges and hillslopes, and coniferous (Pinus (pine), Tsuga (hemlock)) at higher elevations and along stream networks (Day et al. 1988, Slayer 2014).

The region's climate is characterized as humid marine in the eastern/Atlantic coastal area and humid continental on the western edge (Konrad and Fuhrmann 2013). Mean annual temperature ranges from $9.3^{\circ} \mathrm{C}$ in the mountains to $14.7^{\circ} \mathrm{C}$ near the ocean, and increases with decreasing latitude, with the northernmost Ohio River basin averaging $10.5^{\circ} \mathrm{C}$, and the southernmost Tennessee River basin averaging $15^{\circ} \mathrm{C}$. P is relatively evenly distributed throughout the year, dominated by small, low intensity storms with intermittent high intensity frontal thunderstorm events (Keim 1996, 1997, Konrad and Fuhrmann 2013). Annual P increases with elevation from $1034 \mathrm{~mm}$ in the Potomac River basin to $1870 \mathrm{~mm}$ in the Tennessee River basin. Average annual ET loss is $\sim 75 \%$ of annual rainfall in all watersheds except the Monongahela, the most heavily forested basin, which averages $~ 51 \%$ of $\mathrm{P}$ (Miller and Weaver 1971, Farnsworth and Thompson 1983, Harstine 1991, Ford et al. 2005, Adams et al. 2012).

\subsubsection{Data}

\subsubsection{Vegetation phenology from satellite imagery}

For this study, we extracted long term phenological records from the Global Inventory Modeling and Mapping Studies (GIMMS) third generation Normalized Difference Vegetation Index (NDVI3g) to characterize the temporal trends in regional scale phenology (Hong and Zhang 2006, Prebyl 2012). NDVI3g is produced from data acquired by the Advanced Very High 
Resolution Radiometer (AVHRR) on board the National Oceanic and Atmospheric Administration (NOAA) satellite series (Pinzon and Tucker 2014). NDVI data were extracted from October 1982 to September 2012 to quantify recent changes in growing season length throughout the region.

Data were quality-controlled based on data reliability where pixels with weak or noisy time series (e.g. quality flag greater than 3), NDVI values that were negative, equal to zero, or greater than 1.0, high outlier values, or Julian day greater than 365 , were removed for the analysis. The TIMESAT program (Jönsson and Eklundh 2004) was used to produce a smoothed NDVI time series dataset from 1982 to 2012. TIMESAT incorporates an automated medianspike pre-processing technique to remove spikes and outliers (Vidal and Amigo 2012). The Asymmetric Gaussian function was used to fit a smooth continuous curve to extract phenological signals from the data (Figure 3). NDVI values between 0.8 and 1.0 that represent dense forested land-cover were selected for this analysis. Data output were in annual time series sets (e.g. 31 years per derived phenological attribute per pixel). Start of season (SOS) and end of season (EOS) were estimated as the date where NDVI increased or decreased to $50 \%$ of the amplitude, representing canopy development and senescence respectively, and length of season (LOS) was calculated as end of season minus the SOS (Figure 3) (White et al. 1999, White et al. 2009).

\subsubsection{Hydrologic Variables}

Mean annual streamflow data for the $31 \mathrm{HCDN}$ watersheds were obtained from the USGS historical water dataset (http://waterdata.usgs.gov) using R (RCore 2013, Hirsch and De Cicco 2015). Streamflow data were then normalized by area, and averaged annually to produce mean annual $Q$.

Actual ET in mm/year was estimated using the annual water balance, assuming no change in storage

$$
E T=P-Q+\Delta S
$$

where $P$ is $\mathrm{P}, Q$ is average $\mathrm{Q}$, and $\Delta S$ is watershed storage (e.g. groundwater, soil moisture, vegetation/root) which approaches zero on an annual scale, all in mm/year. 


\subsubsection{Climate Variables}

Annual maximum and minimum vapor pressure deficit and dew pressure temperature data were extracted from PRISM (Parameter Elevation Regression on Independent Slopes) (Daly et al. 1997). PRISM uses 13,000 $\mathrm{P}$ and 10,000 surface temperature data stations over the conterminous US to spatially interpolate $\mathrm{P}$ and temperature using a Digital Elevation Model (DEM) to estimate orographic effects. PRISM is gridded at a $4 \mathrm{~km}$ spatial resolution at the daily time scale, and covers the period from 1895 to the present (Daly et al. 2008).

Ten annual climate variables (maximum and minimum temperature, P, potential ET, maximum and minimum relative humidity, solar radiation, wind direction, wind speed, specific humidity) were extracted from the gridded (4 km spatial resolution) MetData meteorological dataset (Table 1) (Abatzoglou and Brown 2012). MetData was developed by combining the hourly and $1 / 8^{\text {th }}$ degree resolution North America Land Data Assimilation System Phase 2 (NLDAS-2) dataset with the monthly $4 \mathrm{~km}$ resolution PRISM dataset from 1979-2015 (see Abatzoglou and Brown (2012))). Potential ET was calculated using the Penman-Monteith equation (Penman 1948) forced with solar radiation, dew point temperature, wind speed, and evaporation. Wind direction was normalized to account for the 0-360-degree direction. Using wind speed and wind direction angle, we calculated the $x$ and $y$ components using trigonometric functions (Breckling 2012). All daily variables predicting growing season were aggregated to US annual water year (October 1 - September 31). However, all variables used to predict evapotranspiration were conducted using the vegetation year (May-April) (Troch et al. 2009) using R (RCore 2013). Vegetation year minimizes the delta storage term in estimating evapotranspiration from precipitation by accounting for soil moisture depletion from a longer growing season the current year and the subsequent altered stream discharge patterns the following dormant season. This is especially effective in estimating ET given the central Appalachian region does not have dominant snowpack (Troch et al. 2009).

\subsubsection{Statistical methods}

\subsubsection{Quantifying trends in climate and growing season length}

The rank-based, non-parametric Mann Kendall statistical test was used to detect trends in climate, hydrology, and growing season variables (Helsel and Hirsch 1992). Mann Kendall allows for non-normally distributed data (Andreadis and Lettenmaier 2006) and allows for 
missing values (Hirsch and Slack 1984) and is commonly used for detecting trends in hydrology and hydro-meteorological studies (Yue et al. 2002). Trends were considered significant at the $\alpha=0.05$ level. The direction and magnitude of the time series trends were estimated using the Kendall Thiel Sen slope, which identifies the median slope among all lines through a time series (Helsel and Hirsch 1992). Total change over the 31-year study period was estimated by multiplying slope by the number of years of data (i.e. 31 years) (Zegre et al. 2014).

\subsubsection{Identifying important components of growing season length change}

\subsubsection{Principle Component Analysis}

Given the large number of potential explanatory variables that drive growing season length, a principle components analysis (PCA) (Bibby et al. 1979) was used to reduce the dimensionality of the variables. The original dataset included 14 predictor variables: thirteen climate variables $(\mathrm{P}$, specific humidity [sph], average annual minimum [rmin] and maximum relative humidity [rmax], solar radiation $[\mathrm{srad}]$, dew pressure temperature $[\mathrm{dpt}]$, average annual minimum [tmin] and maximum temperature [tmax], potential evapotranspiration [PET], wind direction [th], and wind speed [vs], maximum [vpdmax] and minimum vapor pressure deficit [vpdmin], and one hydrology variables (Q). The input data represented a three-dimensional matrix, comprising the climate/hydrology as the variables in one dimension, with time and space as the remaining two dimensions, yielding $\sim 14,000$ observations (31 years*31 sites) for each of the 15 variables. Standardized principle component analysis was implemented using R. Principle components with eigenvalues $>1.0$ were regarded as carrying important information, and factor loadings rounding to an absolute value $\geq 0.4$ were considered important in determining a particular component (McCune et al. 2002).

A correlation matrix between climate and hydrologic variables was developed to remove statistically redundant variables. A Pearson correlation matrix was developed using R (RCore 2013). All correlation values greater than 0.7 were considered strongly related (e.g. $r> \pm 0.7$ ) (Ratner 2009).

\subsection{Mixed Effects Model}

A linear mixed effects model (Zuur et al. 2009) was developed to identify the important climatic variables in growing season length using the explanatory variables identified by the 
PCA. A linear mixed effects model is a statistical correlation model used to identify interactions between variables in a longitudinal study, with applicability in multiple disciplines including physical, biology, and social sciences. Linear mixed effects models contain fixed and random components (Zuur et al. 2009), which allows for spatial and temporal variability in site-specific topography, climate, geography, and time. We validated our model by randomly splitting data into training $(80 \%, \mathrm{n}=11,532)$ and test $(20 \%, \mathrm{n}=2884)$ data. The model was developed by iteratively dropping fixed and random parameters (Arnold 2010). All dropped parameters that increased the Akaike Information Criteria (AIC) value $>2$ were removed to develop the final model (Arnold 2010). Model performance was evaluated using the AIC values, root mean square error, marginal coefficient of determination, which is the variance explained by fixed effects, and conditional coefficient of determination, which is the variance explained by fixed and random effects together (collectively R²) using R (Bartoń 2013, RCore 2014).

\subsubsection{Interaction of growing season length and evapotranspiration change}

\subsubsection{Principle Component Analysis}

To reduce the dimensionality of the potential explanatory variables important to ET, a PCA was conducted on 17 climatic variables. The PCA included three growing season variables (start of season [SOS], end of season [EOS], length of season [LOS]), thirteen climate variables (P, specific humidity [sph], average annual minimum [rmin] and maximum relative humidity [rmax], solar radiation [srad], dew pressure temperature [dpt], average annual minimum [tmin] and maximum temperature [tmax], potential evapotranspiration [PET], wind direction [th], and wind speed [vs], maximum [vpdmax] and minimum vapor pressure deficit [vpdmin], and one hydrology variable (Q).

The input data represented a three-dimensional matrix, comprising the climate/phenology as the variables in one dimension, with time and space as the remaining two dimensions, yielding $\sim 18,000$ observations ( 31 years*31 sites) for each of the 17 variables. A correlation matrix between growing season, climate, and hydrologic variables was developed to remove statistically redundant variables.

To identify if growing season influences ET, a second mixed effects model was developed using the important variables identified by the PCA as fixed effects and site and year as random effects. The final model was similarly developed by iteratively dropping variables that 
increased the AIC value $>2$. Model performance was evaluated using the AIC values, root mean square error, marginal coefficient of determination, and conditional coefficient of determination. The model was validated by randomly splitting data into training $(80 \%, \mathrm{n}=14,607)$ and test $(20 \%, \mathrm{n}=3651)$ data.

\subsection{Results}

\subsubsection{Question 1: How has climate and growing season length changed?}

\subsubsection{Climate}

Measured air temperatures generally increased across the watersheds over the 31 years studied. Maximum temperatures averaged $17.3^{\circ} \mathrm{C}$ across the watersheds, and although most individual watersheds indicated warming temperatures, trends were not significant at $\alpha=0.05$ for any watersheds (Table 2). Minimum temperatures increased significantly in 14 individual watersheds, increasing on average, by $0.2^{\circ} \mathrm{C}$. Solar radiation, which averaged $172.0 \mathrm{~mW} \mathrm{~m}^{-2}$ across all watersheds increased significantly in 10 watersheds by an average of $5.7 \mathrm{~mW} \mathrm{~m}^{-2}$ on average (SI Table 3). Potential evapotranspiration, which averaged $1076.0 \mathrm{~mm}$ across all watersheds, increased significantly by $64.9 \mathrm{~mm}$ in only one watershed. Minimum vapor pressure deficit, which averaged $0.72 \mathrm{hPa}$ across watersheds, significantly decreased by $-0.008 \mathrm{hPA}$ in 17 watersheds (SI Table 3). Maximum vapor pressure deficit, which averaged $12.09 \mathrm{hPa}$ across watersheds, significantly increased by $0.05 \mathrm{hPa}$ at one watershed. Specific humidity, which averaged $0.7 \mathrm{~g} / \mathrm{kg}$ across watersheds, significantly increased by $0.6 \mathrm{~g} / \mathrm{kg}$ at one watershed (SI Table 3). Similarly, maximum relative humidity, which averaged $89 \%$, significantly decreased by $2.2 \%$ on average, at eight watersheds (Table 2 ).

Wind, which is an important component of ET, also has increased across watersheds. Over the 31-year period studied, the average wind direction, calculated as degrees from north, was $254^{\circ}$, and has shifted $16^{\circ}$ counter-clockwise to $238^{\circ}$ in all watersheds, suggesting an increased northwesterly component (Table 2). Wind speed, which averaged $1.2 \mathrm{~m} / \mathrm{s}$ across all watersheds, significantly increased at 21 watersheds by an average of $0.15 \mathrm{~m} / \mathrm{s}$ (Table 2).

\subsubsection{Hydrology}

Water balance variables, including P, ET, and Q, also provide some evidence of change over the 31 years studied. P, which averaged $1126 \mathrm{~mm}$ across watersheds, increased in all but 
four watersheds by an average of $34 \mathrm{~mm}$, although the change was not significant. Q averaged $512.0 \mathrm{~mm}$ across watersheds, and similar to $\mathrm{P}$, changes were not significant at any individual watershed (SI Table 3). Although P and Q changes were not significant, variability tends to be minimized in water balance calculations, and thus ET potentially provides a more reliable record (Koster and Suarez 1999, Sankarasubramanian and Vogel 2002). Hence, ET was used, instead of $\mathrm{Q}$ as a response variable because it eliminates monthly variability given its dependency on available energy rather than $\mathrm{P}$ events thereby providing a more stable water response variable (Coopersmith et al. 2012, Fernandez and Sayama 2015). ET, which averaged $613.0 \mathrm{~mm}$ across watersheds, increased in 28 watersheds, nine of which were significant. Across the entire region ET increased by $12.7 \mathrm{~mm}$ on average, for the statistically significant watersheds the increase was $22 \mathrm{~mm}$ (Table 2).

\subsubsection{Growing Season Length}

The results of the Mann Kendall trend analysis for growing season length indicated that SOS and EOS have changed significantly $(\alpha=0.05)$ across the region. SOS has advanced (i.e. spring is earlier) significantly in 25 watersheds by an average of 16.3 days. EOS has retreated (i.e. senescence is later in the year) by an average of 10.7 days and was significant at all watersheds (SI Table 3). The LOS, which averaged 179 days, increased significantly in 30 of the 31 sites, by an average of 22.2 days (Table 2).

Growing season length increases, as shown in the map of growing season changes from 1982-2012 (e.g. LOS 2012-LOS 1982) (Figure 1b) were greatest in the southern extent of the Ohio river basin, increasing by as much as 70 days in some areas. Watersheds in the Kanawha and northern Tennessee basins increased the least, with changes that ranged from 0-15 days in some areas (Figure 1b).

\subsubsection{Question 2: What are the predictors of growing season length?}

The first PCA analysis focused on the climate variables that potentially could be used in the mixed effect model for predicting growing season length, and the results were used to guide variable selection for the model. Four growing season length components were significant. Component 1 , which explained $43 \%$ of the variance was characterized by an energy signature; component 2 , which explained $25 \%$ of the variance, was characterized by a moisture availability 
signature; component 3 , which explained $8.5 \%$ of the variance, consisted of evaporative turbulence signature; and component 4 , which explained $6.5 \%$ of the variance, consisted of an evaporative demand signature (SI Table 4). Maximum temperature was correlated with dew

pressure temperature $\left(\mathrm{R}^{2}=0.82\right)$, potential evapotranspiration $(0.85)$, and minimum temperature $\left(\mathrm{R}^{2}=0.87\right)$ therefore, potential evapotranspiration, dew pressure temperature, and minimum temperature were eliminated from the model since maximum temperature had a higher factor loading.

The PCA analysis identified eight variables that were potentially important inputs for the mixed effect model: maximum temperature, specific humidity, relative humidity, wind direction, wind speed, precipitation, solar radiation, and minimum vapor pressure deficit as fixed effects. The optimal effect structure included random intercepts and slopes around year and site (SI Table 4).

The final model of growing season length showed significant fixed effects at alpha $=0.05$ for maximum temperature ( $p$-value $=0.008$ ), minimum vapor pressure deficit ( $p$-value $=0.034$ ), wind direction ( $\mathrm{p}$-value $=0.024$ ), and wind speed ( $\mathrm{p}$-value $=0.02$ ). Significant interactive effects included maximum relative humidity and specific humidity ( $\mathrm{p}$-value $=0.024$ ), maximum temperature and vapor pressure deficit ( $\mathrm{p}$-value $=0.04$ ), and vapor pressure deficit with wind speed (p-value: 0.017) (SI Table 5). Together, fixed and random effects explained $88.3 \%$ of total variance in growing season length with a conditional $\mathrm{R}^{2}=0.88$. Fixed effects explained $7.7 \%$ of the overall variation with a marginal $\mathrm{R}^{2}=0.077$. When predicting growing season changes with the evaluation dataset, the final model had an overall root mean square error and uncertainty value of \pm 3.4 days.

\subsubsection{Question 3: Does growing season length influence evapotranspiration?}

The second PCA analysis focused on the variables that could potentially be used to identify ET controls. Four significant principle components were identified for ET. Component 1 , which explained $35 \%$ of the variance, was characterized by an energy signature. Component 2 $(20 \%)$, was characterized by a moisture availability signature. Component $3(11 \%)$, was characterized by a growing season signature. Component $4(8 \%)$ was characterized by an evaporative demand signature (SI Table 6). 
Thus, the variables included in the mixed effect model were maximum temperature, specific humidity, relative humidity, LOS, wind speed and wind direction, as well as the random effects of year and site. The list excluded potential evapotranspiration because it was significantly correlated with maximum temperature, and the latter had a higher loading in the PCA. Similarly, SOS and EOS were also eliminated from the model, since these variables were significantly correlated with LOS, which had the highest loading $(0.59)$ of the three variables.

The final mixed effects model identified relative humidity as a significant predictor of ET at alpha $=0.1$ ( $p$-value $=0.059$, respectively). $\operatorname{LOS}$ was not a significant individual variable but the interaction of LOS with maximum temperature, maximum relative humidity, specific humidity, wind speed, wind direction, and solar radiation resulted in a more optimal model (SI Table 7). Together, fixed and random effects explained $85 \%$ of the total variance in ET (conditional $\mathrm{R}^{2}=$ 0.846 ). Fixed effects explained $0.8 \%$ of the total variance (marginal $\mathrm{R}^{2}=0.0081$ ). The final model had an overall root mean square error of $87.2 \mathrm{~mm}$ when predicting ET with evaluation data.

\subsection{Discussion}

\subsubsection{Question 1: How has climate and growing season length changed?}

Previous studies have shown that air temperatures in the mid- and south-Atlantic region of the US that includes the central Appalachian region have increased between $0.5-1.9^{\circ} \mathrm{C}$, on average (Pitchford et al. 2011, Patterson et al. 2012). Higher air temperature increases the capacity of the atmosphere to hold water, theoretically leading to intensification of the hydrologic cycle in the form of accelerated rates of ET and P (Trenberth et al. 2007, Huntington 2010). Greater rates of ET occur in response to increasing atmospheric and evaporative demand including vapor pressure deficit, wind turbulence, and rainfall inputs. These ideas are summarized by the Clausius-Clapeyron relation (Figure 4), which states that with increasing temperatures, atmospheric water vapor exponentially increases by between $3.4 \% / \mathrm{K}$ (Allen and Ingram 2002) and 7\%/K (Held and Soden 2000), although there is debate about whether the water vapor increases associated with climate warming follows the higher or lower rate (Allen and Ingram 2002). Our results are theoretically consistent with the Clausius-Clapeyron relation, albeit at the lower slope $\left(4.095 \mathrm{e}^{0.03 x}\right)$, equivalent to $3.4 \% / \mathrm{K}$ rather than $7 \% / \mathrm{K}$ that has a slope of $2.56 \mathrm{e}^{0.06 \mathrm{x}}$ (Figure 4). 
Increasing temperatures and water availability for tree growth over the study period from 1982-2012 have resulted in a lengthened growing season by 22 days on average throughout the central Appalachian Mountains region. Greater change was observed in the spring (16 days) than the change during the senescence in the fall (10 days). Regional and local trends documented in previous studies corroborate this. SOS in the northeastern United States has increased by 13 days from 1982-2012 (0.44 days/year) (Wolfe et al. 2005, Hayhoe et al. 2006), while EOS across the eastern United States has retreated by 12.4 day from 1982-2012 (0.4 days/year) (Dragoni and Rahman 2012). In an earlier study of spring onset in the eastern United States, spring date advanced by 10 days from 1965-1980 (Fitzjarrald et al. 2001) and it is likely to continue into the future (see Hayhoe et al. (2006)). Therefore, it is important to understand the exact mechanisms behind changes in growing season length to increase confidence in prediction and modelling to maintain freshwater sustainability in temperate forest watersheds.

\subsubsection{Question 2: What are the predictors of growing season length?}

Our results at the landscape level are supported by controlled greenhouse experiments that employed canopy warming methods, which found that air temperatures alone under-predicts observational growing season responses (Wolkovich et al. 2012) and do not explain variations in growing season length due to climate change (Marchin et al. 2015). In general, our results show that a suite of climatic variables that include air temperature, vapor pressure deficit, wind, and humidity explain the greatest amount of variation in growing season length changes in the region. These factors were also shown to be important for vegetation growth in the Qing-Tibetan plateau in China (Hu et al. 2011, Shen et al. 2014). Atmospheric principles can theoretically explain this relationship in which temperatures and changing winds result in higher vapor pressure deficit and evaporative demand (Williams and Baeza 2007, Will et al. 2013), which subsequently increases atmospheric humidity, a process we collectively refer to as atmospheric water. From these results, we postulate that growing season length responds to temperature and atmospheric water through that Clausius Clapeyron relation, rather than temperature alone. This is consistent with climate chamber experiments which have shown that atmospheric water influences growing season changes via earlier bud burst under constant temperatures (Laube et al. 2014). Furthermore, statistical models with the inclusion of atmospheric water variables explained $27 \%$ more of the variation than models with temperature alone (temperature alone $=$ 
$60 \%$ (Liang et al. 2012)), suggesting that there is an interactive effect of temperature and atmospheric humidity on growing season length.

We propose two possible explanations for growing season length responses to atmospheric water and other atmospheric properties: winter dehydration and carbohydrate storage cost/benefit. First, it has been suggested that in aboveground tissues (e.g. xylem), winter dehydration occurs in response to stable low air humidity during cold periods (Laube et al. 2014). Consequently, long cold/dry spells lead to greater dehydration and require higher spring humidity to reach tissue moisture for spring onset (Laube et al. 2014). Trees may detect the onset of growing season through higher minimum temperatures and spring humidity, and the subsequent rehydration of aboveground tissue. Vegetation response to humidity may alleviate the frost damages associated with variable changes in springtime minimum temperatures.

Second, we propose that plants respond to increased availability of resources including humidity, temperature, and solar radiation though a cost/benefit process. The greatest plant carbohydrate storage occurs during direct sunlight, high water content, and nutrient availability (Chapin et al. 1986a). Daily, short term, or seasonal fluctuations alter carbohydrate storage levels (Chapin et al. 1986b), with the lowest levels occurring during rapid growth and senescence (Chapin 1977). This is also the point when respiration and growth demands exceeds net carbon gains (Nelson and Dickson 1981). Since plants use carbohydrates acquired during photosynthesis before using stored reserves (Tromp 1969), senescence represents a point when the cost of using stores needed for spring growth outweighs limited carbon gains from photosynthesis (Estiarte and Peñuelas 2015). Plants therefore recycle available leaf nutrients back to storage organs (Titus and Kang 1982). However, a longer growing season with warmer temperatures, direct sunlight, and higher water availability increases the period of net carbon gains, therefore, allowing plants to uptake and store more nutrients for the following (earlier) spring growth period (Chapin III et al. 1990, Keenan and Richardson 2015, Manzoni et al. 2015).

Current research suggests that leaf out timing is very sensitive to springtime night-length and minimum temperatures (Saxe et al. 2001, Sakai and Larcher 2012). Our model did not account for the interaction between atmospheric water and minimum temperatures, because our model was developed using annual variables and could not capture the interannual variability. Our study therefore suggests that temperature and humidity work synergistically in annual growing season length changes, although inter-annual variations are likely to be important but 
beyond the scope of our study. Future research should explore the importance of atmospheric water vapor in identifying inter-annual nuances of green-up and senescence. Current annual prediction models such as the Spring Indices model (Schwartz 1997), use temperature-based indices and are frequently used throughout the eastern United States (Schwartz 1997). Hayhoe et al. (2006)) used this model to predict growing season length changes throughout the northeast US. Future research should focus on developing a temperature and atmospheric water based index to use in growing season length prediction models (Richardson et al. 2012). Growing season prediction models provides data that allow managers and policy makers to prepare for future changes to watershed sustainability. Future temperature and specific humidity are projected to increase in coming decades (IPCC 2007), suggesting that single years with unusually high temperature and humidity conditions will potentially result in increasingly unpredictable growing season lengths (e.g. more variability), unreliable forest water cycling/water partitioning, greater long-term ET, and increased occurrences of drought.

\subsubsection{Question 3: Does growing season length influence evapotranspiration?}

The central Appalachian region is over $80 \%$ forested (Slayer 2014) and returns $>40 \%$ of $\mathrm{P}$ back to the atmosphere as ET. In the southern Appalachia mountains in North Carolina, a one day increase in growing season increased ET by $4.3 \mathrm{~mm}$ (Hwang et al. 2014, Hwang et al. 2018, Kim et al. 2018), and in the eastern US, a one day increase in growing season increases ET by $0.2 \%$ (or approximately $1 \mathrm{~mm} / \mathrm{year}$ ) (White et al. 1999), as compared to a $0.5 \mathrm{~mm}$ increase in our study in central Appalachia. The smaller increase in ET in our study area could be due to reduced water use efficiency, ecosystem dynamics, and land use land cover (LULC) change. First, the effect of increased $\mathrm{CO}_{2}$ concentration on water use efficiency is outweighed by a longer growing season (Warren et al. 2011). Second, it is also likely that ecosystem dynamics in the semi-dry, energy limited ecosystems do not always represent higher evapotranspiration at all times. Vegetation in these ecosystems have evolved preventative drought stress stomatal dynamics that can decouple the link between increased growing season and evapotranspiration change. Third, forest cover in the study area averages between 60 and 65\%, with forests in some areas covering less than 50\% and in other areas almost 100\% (Figure 2). ET increases in the heavily forested areas in sites with high forest cover was likely averaged out with calculating whole watershed scale ET. A one day growing season increase in watersheds that had greater 
than $65 \%$ forest cover averaged around $0.78 \mathrm{~mm} /$ one day growing season increase (not shown), suggesting that the agricultural regions reduced ET cycling signals upwards of $0.28 \mathrm{~mm} /$ growing season day. Eight watersheds are more than 30\% hay/pasture/agricultural, which is also likely to increase water yield given the occurrences of more intense rainstorms following hydrologic intensification (Huntington and Billmire 2014). Furthermore, any LULC changes, such as deforestation that has occurred from 1982-2012 could mitigate increasing ET signals due to reduced ET cycling in agricultural and urban centers. Therefore, while the lengthened growing season may at least partially influence evapotranspiration trends throughout the central Appalachian region, the intensity of the interaction between growing season and evapotranspiration may vary annually based on water supply conditions. Nevertheless, this analysis gives an indication of a range of potential ET rates (e.g. 0.5 to $4.3 \mathrm{~mm}$ ) that can occur with a one-day growing season increase in temperate forests.

ET will likely continue to increase in the future, as growing season length continues to increase, having important implications for forested ecosystems that provide clean and stable water to downstream communities. Higher ET has the potential to lead to reduced plant water content, reduced soil moisture, greater incidences of droughts, and decreased long-term water supply to downstream communities. Based on our results, we suggest that scientists implement humidity-based growing season properties such as SOS, EOS, and/or LOS into ET and Q prediction models. Although ET in many large-scale models implicitly react to the atmospheric conditions that drive growing season, an explicit representation of humidity based growing season properties could improve the models. The Lund-Potsdam-Jena managed Land (LPJmL) large scale hydrological model (Bondeau et al. 2007), for example, incorporates phenology and other vegetation characteristics allowing for a dynamic growing season representation (Bondeau et al. 2007). However, this may also bring an additional source of uncertainty to Q and ET predictions (Haddeland et al. 2011). Given this assumption, we suggest that models update processing to allow for optional inclusion of phenology and humidity indices, to provide a more accurate prediction of Q and ET for maintaining sustainable forests and freshwater resources.

\subsection{Conclusions and Future Directions}

To understand the role of forests in provisioning water under changing climate, this research determined historical changes in climate, growing season, and ET, investigated the 
important atmospheric variables effecting growing season length changes, and identified the interaction growing season and evapotranspiration variables. Historical annual growing season length has increased by an average of 22 days while annual ET increased by $12.7 \mathrm{~mm}$ across the central Appalachian region of the United States.

Current research suggests that temperature (Morin et al. 2010, Dragoni and Rahman 2012) and photoperiod alone (Bauerle et al. 2012) are the primary indicators of spring. In general, our results show that multiple climatic variables including temperature, vapor pressure deficit, wind, and humidity are important factors effecting growing season length changes. We postulated that these variables interact synergistically to increase atmospheric water and growing season length through the Clausius-Clapeyron relation. Additionally, over 30 years, a 1.0 day increase in growing season length has generally increased ET by up to $0.5 \mathrm{~mm}$, suggesting that longer growing season may partially influence evapotranspiration trends.

Our research provides important insight into the atmospheric processes responsible for phenology trends and the interaction between climate change induced growing season length and forest ET in eastern US temperate forests. These results will provide important insights for modeling future growing season length and hydrology through the addition of an explicit humidity-based index in current models. The results of this research are likely applicable to temperate forests around the globe that provide potentially valuable information to water resource managers for maintaining watershed sustainability in water-stressed large global population centers reliant on headwater basins for drinking water and other ecosystem services.

\subsection{Acknowledgments}

Funding for this research was support, in part, by the National Science Foundation Award Number OIA-148952 and the USDA National Institute of Food and Agriculture Hatch project \#1004360 awards to Zegre, and the West Virginia University Mountains of Excellence Water Resources STEM Fellowship to Gaertner. Any opinions, findings, and conclusions or recommendations expressed in this material are those of the authors and do not necessary reflect the view of the National Science Found or the USDA. The dataset METDATA was produced by Northwestern University with funding from the NSF Idaho EPScoR Program, the National Science Foundation award number EPS-0814387, and the National Institute for Food and Agriculture competitive grant award 2011-68002-30191. 


\section{REFERENCES:}

Abatzoglou JT, Brown TJ. A comparison of statistical downscaling methods suited for wildfire applications. International Journal of Climatology 2012; 32: 772-780.

Adams MB, Edwards PJ, Ford WM, Schuler TM, Thomas-Van Gundy M, Wood F. Fernow experimental forest: research history and opportunities, 2012.

Allen MR, Ingram WJ. Constraints on future changes in climate and the hydrologic cycle. Nature 2002; 419: 224-232.

Andreadis KM, Lettenmaier DP. Trends in 20th century drought over the continental United States. Geophysical Research Letters 2006; 33.

ARC. Subregions in Appalachia. Appalachian Regional Commission, 1970.

Arnold TW. Uninformative parameters and model selection using Akaike's Information Criterion. Journal of Wildlife Management 2010; 74: 1175-1178.

Bartoń K. MuMIn: Multi-model inference. R package version 1.9. 13. The Comprehensive R Archive Network (CRAN), Vienna, Austria 2013.

Bauerle WL, Oren R, Way DA, Qian SS, Stoy PC, Thornton PE, et al. Photoperiodic regulation of the seasonal pattern of photosynthetic capacity and the implications for carbon cycling. Proceedings of the National Academy of Sciences 2012; 109: 8612-8617.

Bibby J, Kent J, Mardia K. Multivariate analysis. Academic Press, London, 1979.

Bondeau A, Smith PC, Zaehle S, Schaphoff S, Lucht W, Cramer W, et al. Modelling the role of agriculture for the 20th century global terrestrial carbon balance. Global Change Biology 2007; 13: 679-706.

Breckling J. The analysis of directional time series: applications to wind speed and direction. Vol 61: Springer Science \& Business Media, 2012.

Caldwell P, Muldoon C, Ford-Miniat C, Cohen E, Krieger S, Sun G, et al. Quantifying the role of National Forest System lands in providing surface drinking water supply for the southern United States. 2014.

Caldwell PV, Miniat CF, Elliott KJ, Swank WT, Brantley ST, Laseter SH. Declining water yield from forested mountain watersheds in response to climate change and forest mesophication. Global change biology 2016; 22: 2997-3012. 
Campbell JL, Driscoll CT, Pourmokhtarian A, Hayhoe K. Streamflow responses to past and projected future changes in climate at the Hubbard Brook Experimental Forest, New Hampshire, United States. Water Resources Research 2011; 47: W02514.

Chapin FS. Nutrient/carbon costs associated with tundra adaptations to a cold nutrient-poor environment. Proc. Circumpolar Conference on Northern Ecology. Nat Res Council of Canada, Ottawa, 1977, pp. 1183-1194.

Chapin FS, McKendrick J, Johnson D. Seasonal changes in carbon fractions in Alaskan tundra plants of differing growth form: implications for herbivory. The Journal of Ecology 1986a: 707-731.

Chapin FS, Shaver G, Kedrowski R. Environmental controls over carbon, nitrogen and phosphorus fractions in Eriophorum vaginatum in Alaskan tussock tundra. The Journal of Ecology 1986b: 167-195.

Chapin III FS, Schulze E, Mooney HA. The ecology and economics of storage in plants. Annual review of ecology and systematics 1990; 21: 423-447.

Chmielewski F-M, Rötzer T. Response of tree phenology to climate change across Europe. Agricultural and Forest Meteorology 2001; 108: 101-112.

Chou C, Neelin JD, Chen C-A, Tu J-Y. Evaluating the "rich-get-richer" mechanism in tropical precipitation change under global warming. Journal of Climate 2009; 22: 1982-2005.

Coopersmith E, Yaeger M, Ye S, Cheng L, Sivapalan M. Exploring the physical controls of regional patterns of flow duration curves-Part 3: A catchment classification system based on regime curve indicators. Hydrology and Earth System Sciences 2012; 16: 4467-4482.

Creed I, Hwang T, Lutz B, Way D. Climate warming causes intensification of the hydrological cycle resulting in changes to the vernal and autumnal windows in a northern temperate forest. Hydrological Processes 2015.

Daly C, Halbleib M, Smith JI, Gibson WP, Doggett MK, Taylor GH, et al. Physiographically sensitive mapping of climatological temperature and precipitation across the conterminous United States. International journal of climatology 2008; 28: 2031-2064.

Daly C, Taylor G, Gibson W. The PRISM approach to mapping precipitation and temperature. Proc., 10th AMS Conf. on Applied Climatology, 1997, pp. 20-23.

Day F, Phillips D, Monk C. Forest communities and patterns. Forest hydrology and ecology at Coweeta. Springer, 1988, pp. 141-149. 
Dingman SL. Physical hydrology: Waveland press, 2015.

Dragoni D, Rahman AF. Trends in fall phenology across the deciduous forests of the Eastern USA. Agricultural and Forest Meteorology 2012; 157: 96-105.

Estiarte M, Peñuelas J. Alteration of the phenology of leaf senescence and fall in winter deciduous species by climate change: effects on nutrient proficiency. Global change biology 2015; 21: 1005-1017.

Farnsworth RK, Thompson ES. Mean monthly, seasonal, and annual pan evaporation for the United States: US Department of Commerce, National Oceanic and Atmospheric Administration, National Weather Service, 1983.

Fernandez R, Sayama T. Hydrological recurrence as a measure for large river basin classification and process understanding. Hydrology and Earth System Sciences 2015; 19: 1919-1942.

Fitzjarrald DR, Acevedo OC, Moore KE. Climatic consequences of leaf presence in the eastern United States. Journal of Climate 2001; 14: 598-614.

Ford CR, Goranson CE, Mitchell RJ, Will RE, Teskey RO. Modeling canopy transpiration using time series analysis: a case study illustrating the effect of soil moisture deficit on Pinus taeda. Agricultural and forest meteorology 2005; 130: 163-175.

Haddeland I, Clark DB, Franssen W, Ludwig F, Voß F, Arnell NW, et al. Multimodel estimate of the global terrestrial water balance: setup and first results. Journal of Hydrometeorology 2011; 12: 869-884.

Harstine LJ. Hydrologic Atlas for Ohio: average annual precipitation, temperature, streamflow, and water loss for 50-year period, 1931-1980: Ohio Department of Natural Resources, Division of Water, Ground Water Resources Section, 1991.

Hayhoe K, Wake CP, Huntington TG, Luo L, Schwartz MD, Sheffield J, et al. Past and future changes in climate and hydrological indicators in the US Northeast. Climate Dynamics 2006; 28: 381-407.

Held IM, Soden BJ. Water vapor feedback and global warming. Annual Review of Energy and the Environment 2000; 25: 441-475.

Held IM, Soden BJ. Robust responses of the hydrological cycle to global warming. Journal of Climate 2006; 19: 5686-5699.

Helsel DR, Hirsch RM. Statistical Methods in Water Resources. Amsterdam: Elsevier, 1992. 
Hirsch RM, De Cicco LA. User guide to Exploration and Graphics for RivEr Trends (EGRET) and dataRetrieval: R packages for hydrologic data. US Geological Survey, 2015.

Hirsch RM, Slack JR. A Nonparametric Trend Test for Seasonal Data With Serial Dependence. Water Resour. Res. 1984; 20: 727-732.

Homer C, Dewitz J, Yang L, Jin S, Danielson P, Xian G, et al. Completion of the 2011 National Land Cover Database for the conterminous United States-representing a decade of land cover change information. Photogrammetric Engineering \& Remote Sensing 2015; 81: 345-354.

Hong G, Zhang Y. Object-based change detection in high resolution image. In: Sensing ASfPaR, editor. Proceedings of the ASPRS 2006 Annual Conference, Reno, Nevada, 2006.

Hu MQ, Mao F, Sun H, Hou YY. Study of normalized difference vegetation index variation and its correlation with climate factors in the three-river-source region. International Journal of Applied Earth Observation and Geoinformation 2011; 13: 24-33.

Huntington TG. Climate Warming-Induced Intensification of the Hydrologic Cycle. advances in agronomy 2010; 109: 1-53.

Huntington TG, Billmire M. Trends in precipitation, runoff, and evapotranspiration for rivers draining to the Gulf of Maine in the United States. Journal of Hydrometeorology 2014; 15: 726-743.

Hwang T, Band LE, Miniat CF, Song C, Bolstad PV, Vose JM, et al. Divergent phenological response to hydroclimate variability in forested mountain watersheds. Global change biology 2014; 20: 2580-2595.

Hwang T, Martin KL, Vose JM, Wear D, Miles B, Kim Y, et al. Non-Stationary Hydrologic Behavior in Forested Watersheds is Mediated by Climate-Induced Changes in Growing Season Length and Subsequent Vegetation Growth. Water Resources Research 2018.

IPCC. Climate Change 2007: The physical science basis. Contribution of WG1 to the Fourth Assessment report of the Intergovernmental Panel on Climate Change, 2007.

Jeong S-J, HO CH, GIM HJ, Brown ME. Phenology shifts at start vs. end of growing season in temperate vegetation over the Northern Hemisphere for the period 1982-2008. Global Change Biology 2011; 17: 2385-2399. 
Jones JA, Creed IF, Hatcher KL, Warren RJ, Adams MB, Benson MH, et al. Ecosystem processes and human influences regulate streamflow response to climate change at longterm ecological research sites. BioScience 2012; 62: 390-404.

Jönsson P, Eklundh L. TIMESAT - a program for analyzing time-series of satellite sensor data. Computers \& Geosciences 2004; 30: 833-845.

Keenan TF, Richardson AD. The timing of autumn senescence is affected by the timing of spring phenology: implications for predictive models. Global change biology 2015; 21: 26342641.

Keim BD. Spatial, synoptic, and seasonal patterns of heavy rainfall in the southeastern United States. Physical Geography 1996; 17: 313-328.

Keim BD. Preliminary analysis of the temporal patterns of heavy rainfall across the southeastern United States. The Professional Geographer 1997; 49: 94-104.

Kim JH, Hwang T, Yang Y, Schaaf CL, Boose E, William Munger J. Warming-induced earlier greenup leads to reduced stream discharge in a temperate mixed forest catchment. Journal of Geophysical Research: Biogeosciences 2018.

Konrad CE, Fuhrmann CM. Climate of the southeast USA: past, present, and future. Climate of the Southeast United States. Springer, 2013, pp. 8-42.

Koster RD, Suarez MJ. A simple framework for examining the interannual variability of land surface moisture fluxes. Journal of Climate 1999; 12: 1911-1917.

Laube J, Sparks TH, Estrella N, Menzel A. Does humidity trigger tree phenology? Proposal for an air humidity based framework for bud development in spring. New Phytologist 2014; 202: 350-355.

Lebourgeois F, Pierrat J-C, Perez V, Piedallu C, Cecchini S, Ulrich E. Simulating phenological shifts in French temperate forests under two climatic change scenarios and four driving global circulation models. International journal of biometeorology 2010; 54: 563-581.

Liang L, Schwartz MD, Fei S. Photographic assessment of temperate forest understory phenology in relation to springtime meteorological drivers. International journal of biometeorology 2012; 56: 343-355.

Manzoni S, Vico G, Thompson S, Beyer F, Weih M. Contrasting leaf phenological strategies optimize carbon gain under droughts of different duration. Advances in water resources 2015; 84: 37-51. 
Marchin RM, Salk CF, Hoffmann WA, Dunn RR. Temperature alone does not explain phenological variation of diverse temperate plants under experimental warming. Global change biology 2015; 21:3138-3151.

McCune B, Grace JB, Urban DL. Analysis of ecological communities. Vol 28: MjM software design Gleneden Beach, OR, 2002.

Miller M, Weaver C. Snow in Ohio. Ohio Agricultural Research and Development Center. Research Bulletin 1971; 1044.

Morin X, Roy J, Sonié L, Chuine I. Changes in leaf phenology of three European oak species in response to experimental climate change. New Phytologist 2010; 186: 900-910.

Nelson EA, Dickson RE. Accumulation of food reserves in cottonwood stems during dormancy induction. Canadian Journal of Forest Research 1981; 11: 145-154.

Parker HN, Willis B, Bolster R, Ashe W, Marsh M. The Potomac River Basin. Water Supply and Irrigation Paper 1907; 192: 297.

Patterson LA, Lutz B, Doyle MW. Streamflow Changes in the South Atlantic, United States During the Mid- and Late 20th Century1. JAWRA Journal of the American Water Resources Association 2012; 48: 1126-1138.

Penman HL. Natural evaporation from open water, bare soil and grass. Proceedings of the Royal Society of London A: Mathematical, Physical and Engineering Sciences. 193. The Royal Society, 1948, pp. 120-145.

Pinzon JE, Tucker CJ. A non-stationary 1981-2012 AVHRR NDVI3g time series. Remote Sensing 2014; 6: 6929-6960.

Pitchford J, Wu C, Lin L, Petty J, Thomas R, Veselka W, et al. Climate Change Effects on Hydrology and Ecology of Wetlands in the Mid-Atlantic Highlands. Wetlands 2011: 113.

Prebyl TJ. An analysis of the patterns and processes associated with spring forest phenology in a southern Appalachian landscape using remote sensing. uga, 2012.

Ratner B. The correlation coefficient: Its values range between $+1 /-1$, or do they? Journal of targeting, measurement and analysis for marketing 2009; 17: 139-142.

RCore. R: A language and environment for statistical computing. 2013.

RCore. R: A language and environment for statistical computing. R Foundation for Statistical Computing, Vienna, Austria. 2013. ISBN 3-900051-07-0, 2014. 
Richardson AD, Anderson RS, Arain MA, Barr AG, Bohrer G, Chen G, et al. Terrestrial biosphere models need better representation of vegetation phenology: results from the North American Carbon Program Site Synthesis. Global Change Biology 2012; 18: 566584.

Richardson AD, Bailey AS, Denny EG, MARTIN CW, O'KEEFE J. Phenology of a northern hardwood forest canopy. Global Change Biology 2006; 12: 1174-1188.

Sakai A, Larcher W. Frost survival of plants: responses and adaptation to freezing stress. Vol 62: Springer Science \& Business Media, 2012.

Sankarasubramanian A, Vogel RM. Annual hydroclimatology of the United States. Water Resources Research 2002; 38.

Saxe H, Cannell MG, Johnsen Ø, Ryan MG, Vourlitis G. Tree and forest functioning in response to global warming. New Phytologist 2001; 149: 369-399.

Schwartz MD. Spring index models: an approach to connecting satellite and surface phenology. Phenology in seasonal climates I 1997: 23-38.

Schwartz MD, Ahas R, Aasa A. Onset of spring starting earlier across the Northern Hemisphere. Global Change Biology 2006; 12: 343-351.

Schwartz MD, Reed BC, White MA. Assessing satellite-derived start-of-season measures in the conterminous USA. International Journal of Climatology 2002; 22: 1793-1805.

Shen Z, Fu G, Yu C, Sun W, Zhang X. Relationship between the growing season maximum enhanced vegetation index and climatic factors on the Tibetan Plateau. Remote Sensing 2014; 6: 6765-6789.

Slack JR, Landwehr JM. Hydro-climatic data network (HCDN); a US Geological Survey streamflow data set for the United States for the study of climate variations, 1874-1988. US Geological Survey; Copies of this report can be purchased from USGS Books and Open-File Reports Section, 1992.

Slayer KL. Central Appalachians: Ecoregion Description. 2014, United States Geologic Survey, 2014.

Titus JS, Kang SM. Nitrogen metabolism, translocation, and recycling in apple trees. Horticultural Reviews, Volume 4 1982: 204-246. 
Trenberth KE, Smith L, Qian T, Dai A, Fasullo J. Estimates of the Global Water Budget and Its Annual Cycle Using Observational and Model Data. Journal of Hydrometeorology 2007; 8: 758-769.

Troch PA, Martinez GF, Pauwels VR, Durcik M, Sivapalan M, Harman C, et al. Climate and vegetation water use efficiency at catchment scales. Hydrological Processes: An International Journal 2009; 23: 2409-2414.

Tromp J. Storage and mobilization of nitrogenous compounds in apple trees with special reference to arginine. Long Ashton Symp, 2d, Univ of Bristol, 1969.

U.S._Census_Bureau. National population estimates: Characteristics. http://www.census.gov/popest/national/asrh/NC-EST2005-asrh.html 2009.

Vidal M, Amigo JM. Pre-processing of hyperspectral images. Essential steps before image analysis. Chemometrics and Intelligent Laboratory Systems 2012; 117: 138-148.

Viviroli D, Dürr HH, Messerli B, Meybeck M, Weingartner R. Mountains of the world, water towers for humanity: Typology, mapping, and global significance. Water resources research 2007; 43.

Viviroli D, Weingartner R. The hydrological significance of mountains: from regional to global scale. Hydrology and Earth System Sciences Discussions 2004; 8: 1017-1030.

Wang D, Hejazi M. Quantifying the relative contribution of the climate and direct human impacts on mean annual streamflow in the contiguous United States. Water Resources Research 2011; 47.

Warren JM, Pötzelsberger E, Wullschleger SD, Thornton PE, Hasenauer H, Norby RJ. Ecohydrologic impact of reduced stomatal conductance in forests exposed to elevated CO2. Ecohydrology 2011; 4: 196-210.

White M, Running S, Thornton P. The impact of growing-season length variability on carbon assimilation and evapotranspiration over 88 years in the eastern US deciduous forest. International Journal of Biometeorology 1999; 42: 139-145.

White MA, BEURS D, Kirsten M, DIDAN K, INOUYE DW, RICHARDSON AD, et al. Intercomparison, interpretation, and assessment of spring phenology in North America estimated from remote sensing for 1982-2006. Global Change Biology 2009; 15: 23352359. 
Will RE, Wilson SM, Zou CB, Hennessey TC. Increased vapor pressure deficit due to higher temperature leads to greater transpiration and faster mortality during drought for tree seedlings common to the forest-grassland ecotone. New Phytologist 2013; 200: 366-374.

Williams LE, Baeza P. Relationships among ambient temperature and vapor pressure deficit and leaf and stem water potentials of fully irrigated, field-grown grapevines. American Journal of Enology and Viticulture 2007; 58: 173-181.

Wolfe DW, Schwartz MD, Lakso AN, Otsuki Y, Pool RM, Shaulis NJ. Climate change and shifts in spring phenology of three horticultural woody perennials in northeastern USA. International Journal of Biometeorology 2005; 49: 303-309.

Wolkovich EM, Cook BI, Allen JM, Crimmins TM, Betancourt JL, Travers SE, et al. Warming experiments underpredict plant phenological responses to climate change. Nature 2012; 485: 494.

Yue S, Pilon P, Cavadias G. Power of the Mann-Kendall and Spearman's rho tests for detecting monotonic trends in hydrological series. Journal of Hydrology 2002; 259: 254-271.

Zegre NP, Miller AJ, Maxwell A, Lamont SJ. Multiscale Analysis of Hydrology in a Mountaintop Mine-Impacted Watershed. JAWRA Journal of the American Water Resources Association 2014; 50: 1257-1272.

Zuur A, Ieno E, Walker N, Saveliev A, Smith G. Mixed effects models and extensions in ecology with R. Gail M, Krickeberg K, Samet JM, Tsiatis A, Wong W, editors. New York, NY: Spring Science and Business Media 2009. 
TABLES

Table 1: Summary table for all variables and acronyms

\begin{tabular}{ll}
\hline Variable & Acronym \\
\hline \hline Precipitation & $\mathrm{P}$ \\
Evapotranspiration & $\mathrm{ET}$ \\
Specific humidity & $\mathrm{sph}$ \\
Average annual maximum temperature & tmax \\
Average annual minimum temperature & tmin \\
Average annual maximum humidity & $\mathrm{rmax}$ \\
Average annual minimum relative humidity & $\mathrm{rmin}$ \\
Solar radiation & $\mathrm{srad}$ \\
Dew pressure temperature & $\mathrm{DPT}$ \\
Potential evapotranspiration & $\mathrm{PET}$ \\
Wind direction & th \\
Wind speed & $\mathrm{vs}$ \\
Maximum vapor pressure deficit & $\mathrm{vpdmax}$ \\
Minimum vapor pressure deficit & $\mathrm{vpdmin}$ \\
Runoff & $\mathrm{Q}$ \\
Start of season & $\mathrm{SOS}$ \\
End of season & EOS \\
Length of season & LOS \\
\hline
\end{tabular}


Table 2: Mann Kendal trend table and total change over 31 years for the 31 watersheds in the central Appalachian region. Watershed Identifiers represents each watershed within the five basins, shown in Figure 1. Station number and station name refer to USGS stream gauge identifiers. Bold represents significance at the 0.05 level and bold+italics represents significance at the 0.01 level.

\begin{tabular}{|c|c|c|c|c|c|c|c|c|c|}
\hline $\begin{array}{l}\text { Watershed } \\
\text { Identifier }\end{array}$ & $\begin{array}{l}\operatorname{tmax} \\
\left({ }^{\circ} \mathrm{C}\right)\end{array}$ & $\begin{array}{l}\mathrm{sph} \\
(\mathrm{g} / \mathrm{kg})\end{array}$ & $\begin{array}{l}\operatorname{rmax} \\
(\%)\end{array}$ & $\begin{array}{l}\operatorname{srad} \\
\left(\mathrm{mW} / \mathrm{m}^{2}\right)\end{array}$ & $\begin{array}{l}\text { A. LOS } \\
\text { (days) }\end{array}$ & $\begin{array}{l}\text { th }\left({ }^{\circ} \text { clock- }\right. \\
\text { wise from } \\
\text { north) }\end{array}$ & Vs $(\mathrm{m} / \mathrm{s})$ & $\begin{array}{l}\text { ET } \\
(\mathrm{mm})\end{array}$ & $\begin{array}{l}\text { vpdmin } \\
(\mathrm{hPa})\end{array}$ \\
\hline $1 \mathrm{M}$ & 0.04 & 0.08 & -2.37 & 1.41 & 24.31 & 6.72 & 0.078 & 7.66 & -0.008 \\
\hline $2 \mathrm{M}$ & 0.11 & 0.02 & -2.55 & 1.61 & 23.17 & 8.84 & 0.097 & 27.60 & 0.002 \\
\hline $3 \mathrm{M}$ & -0.02 & 0.17 & 0.34 & 1.83 & 28.18 & 6.51 & 0.101 & 32.52 & -0.007 \\
\hline $4 \mathrm{M}$ & 0.12 & 0.04 & -2.47 & 1.48 & 28.18 & 7.90 & 0.099 & 2.02 & -0.004 \\
\hline $5 \mathrm{M}$ & 0.08 & 0.11 & -1.33 & 1.78 & 31.14 & 7.53 & 0.085 & 19.88 & -0.004 \\
\hline 10 & 0.11 & 0.29 & -1.65 & 4.45 & 22.58 & 12.64 & 0.098 & -2.01 & -0.011 \\
\hline $2 \mathrm{O}$ & 0.16 & 0.25 & -1.83 & 3.30 & 23.94 & 5.73 & 0.126 & 9.62 & -0.009 \\
\hline $1 \mathrm{~K}$ & -0.12 & 0.08 & -1.80 & 1.06 & 5.47 & 14.29 & 0.109 & 3.43 & 0.001 \\
\hline $2 \mathrm{~K}$ & -0.27 & 0.09 & -1.91 & 0.71 & 16.74 & 14.36 & 0.112 & 31.20 & 0.000 \\
\hline $3 \mathrm{~K}$ & -0.31 & -0.13 & -2.30 & 1.03 & 25.36 & 17.98 & 0.156 & 6.21 & 0.001 \\
\hline $4 \mathrm{~K}$ & 0.24 & 0.29 & -0.26 & 3.26 & 24.55 & 13.82 & 0.097 & 17.94 & -0.007 \\
\hline $5 \mathrm{~K}$ & 0.29 & 0.16 & -1.37 & 0.39 & 24.20 & 20.38 & 0.151 & 17.83 & 0.005 \\
\hline $6 \mathrm{~K}$ & 0.02 & -0.03 & -2.00 & 0.61 & 19.45 & 19.79 & 0.146 & 14.39 & 0.001 \\
\hline $7 \mathrm{~K}$ & 0.19 & 0.19 & 1.56 & 0.77 & 19.73 & 23.81 & 0.171 & 11.46 & -0.002 \\
\hline $1 \mathrm{~T}$ & 0.05 & 0.57 & 1.75 & 4.55 & 17.28 & 14.46 & 0.099 & 15.27 & -0.004 \\
\hline $2 \mathrm{~T}$ & 0.36 & 0.30 & -1.21 & 7.36 & 11.67 & 13.94 & 0.052 & 18.33 & 0.011 \\
\hline $3 \mathrm{~T}$ & 0.42 & 0.30 & -0.88 & 6.25 & 16.68 & 13.01 & 0.074 & 42.07 & 0.000 \\
\hline $4 \mathrm{~T}$ & 0.23 & 0.25 & -1.52 & 3.96 & 13.56 & 37.47 & 0.043 & -5.99 & 0.010 \\
\hline $1 P$ & 0.27 & 0.01 & -2.46 & 2.91 & 24.80 & 17.71 & 0.147 & 30.32 & -0.012 \\
\hline $2 \mathrm{P}$ & 0.18 & 0.07 & -1.85 & 3.95 & 23.67 & 15.96 & 0.149 & 15.22 & -0.011 \\
\hline $3 P$ & 0.25 & 0.20 & -0.95 & 4.84 & 25.83 & 20.76 & 0.170 & 8.00 & -0.004 \\
\hline $4 \mathrm{P}$ & 0.08 & 0.08 & -1.95 & 2.18 & 28.22 & 10.84 & 0.098 & 12.36 & -0.013 \\
\hline $5 \mathrm{P}$ & 0.10 & 0.22 & -0.74 & 6.91 & 17.27 & 19.97 & 0.169 & 5.88 & -0.022 \\
\hline $6 \mathrm{P}$ & 0.13 & 0.10 & -1.41 & 4.04 & 26.57 & 17.69 & 0.133 & 5.83 & -0.011 \\
\hline $7 \mathrm{P}$ & 0.27 & 0.27 & -0.44 & 4.78 & 24.58 & 19.80 & 0.146 & -2.49 & -0.007 \\
\hline $8 \mathrm{P}$ & 0.40 & 0.28 & -0.77 & 5.95 & 26.76 & 18.21 & 0.170 & 8.66 & -0.002 \\
\hline 9P & 0.06 & 0.07 & -1.39 & 3.19 & 23.58 & 14.08 & 0.137 & 8.66 & -0.014 \\
\hline $10 \mathrm{P}$ & 0.36 & 0.21 & -0.57 & 6.32 & 24.06 & 18.18 & 0.163 & 11.62 & -0.012 \\
\hline $11 \mathrm{P}$ & 0.17 & 0.20 & -0.88 & 6.25 & 15.19 & 28.95 & 0.168 & 8.37 & -0.016 \\
\hline $12 \mathrm{P}$ & N/A & 0.08 & -0.64 & 3.24 & 17.17 & 12.05 & 0.056 & 3.21 & -0.013 \\
\hline $13 \mathrm{P}$ & 0.03 & 0.16 & -1.79 & 4.03 & 18.53 & 14.06 & 0.040 & 9.48 & -0.007 \\
\hline average & 0.1 & 0.2 & -1.2 & 3.4 & 21.7 & 15.72 & 0.12 & 12.7 & -0.005 \\
\hline $\begin{array}{l}\text { significant } \\
\text { average }\end{array}$ & NA & 0.6 & -2.18 & 5.7 & 22.2 & 15.72 & 0.15 & 22.0 & -0.008 \\
\hline
\end{tabular}

A. Length of growing season (LOS) calculated as SOS-EOS, at 50\% canopy.

*Table only includes variables included in later analysis 


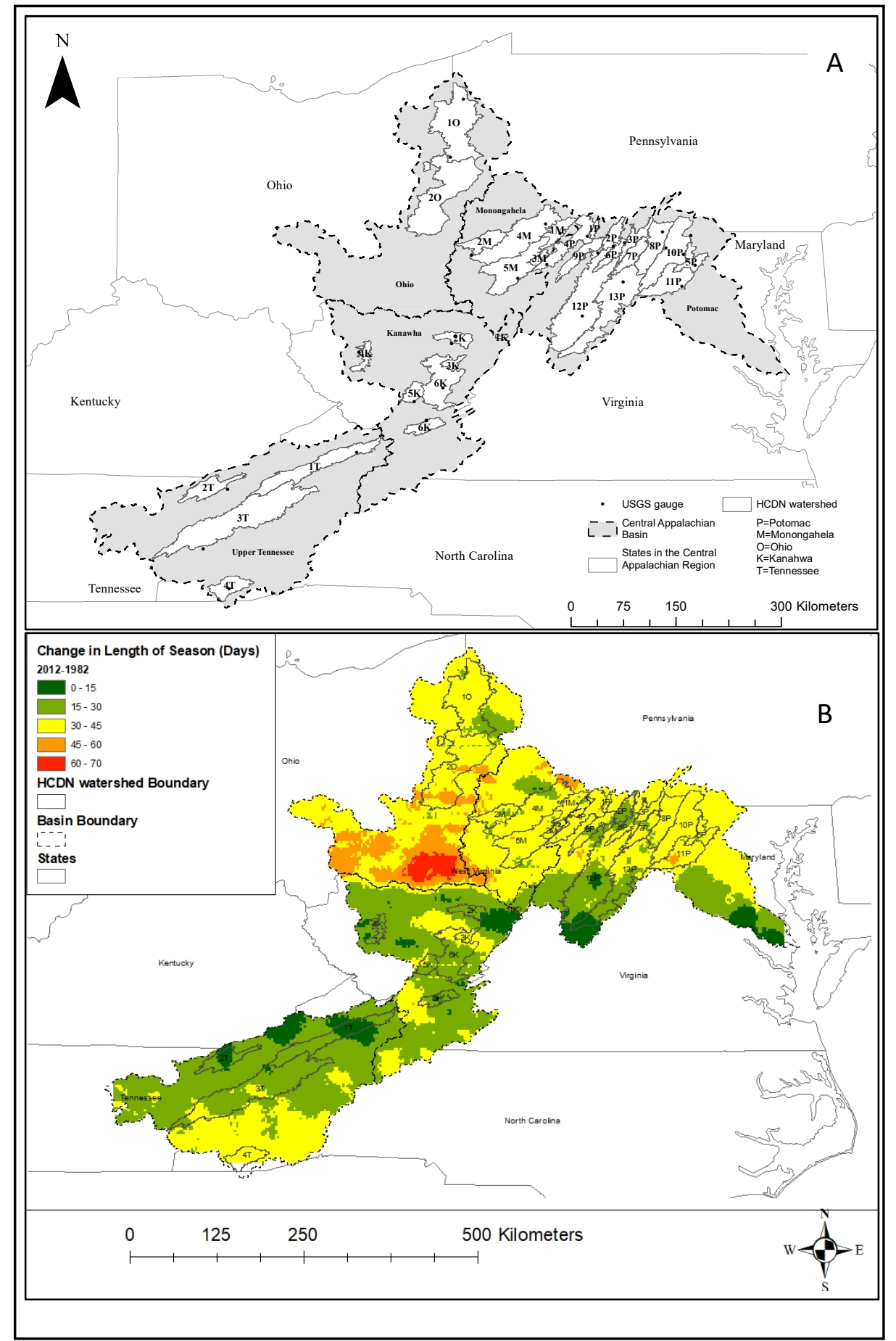

Fig. 2.1 A. Location of the study region in the central Appalachian Mountains region of the eastern USA. B. Study Area depicting the conceptual change in growing season length from 1982 and 2012 (e.g. LOS in 2012 - LOS in 1982). Green regions represent minimal change between the two years (0-15 days) while red represents maximum change (60-70 days). The dashed lines depict basin boundaries Potomac (P), Monongahela (M), Ohio $(\mathrm{O})$, Kanawha $(\mathrm{K})$, and Tennessee $(\mathrm{T})$. The solid lines outline the 31 watersheds, and the identifiers label the basin followed by an HCDN (Slack and Landwehr 1992) watershed number from 1 to $\mathrm{n}$. 


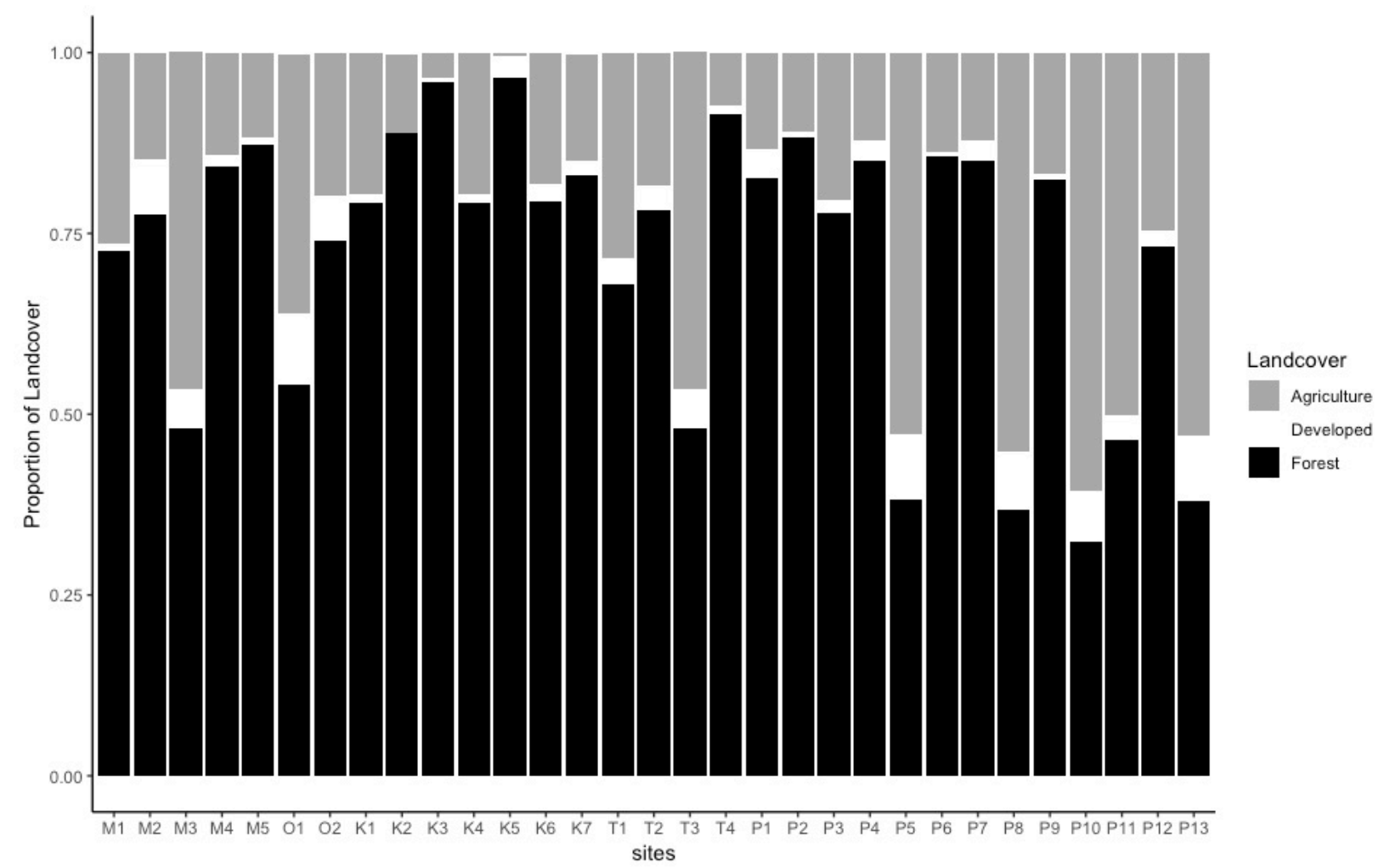

Fig 2.2 Land Cover composition depicting proportion agriculture, developed, and forest for the 31 watersheds based on 2011 NLCD land cover analysis throughout the central Appalachian region. Forests include deciduous, evergreen, and mixed forests, developed includes open space, barren land, low, medium, and high intensity development, and agriculture includes herbaceous, hay/pasture, and cultivated crops. 


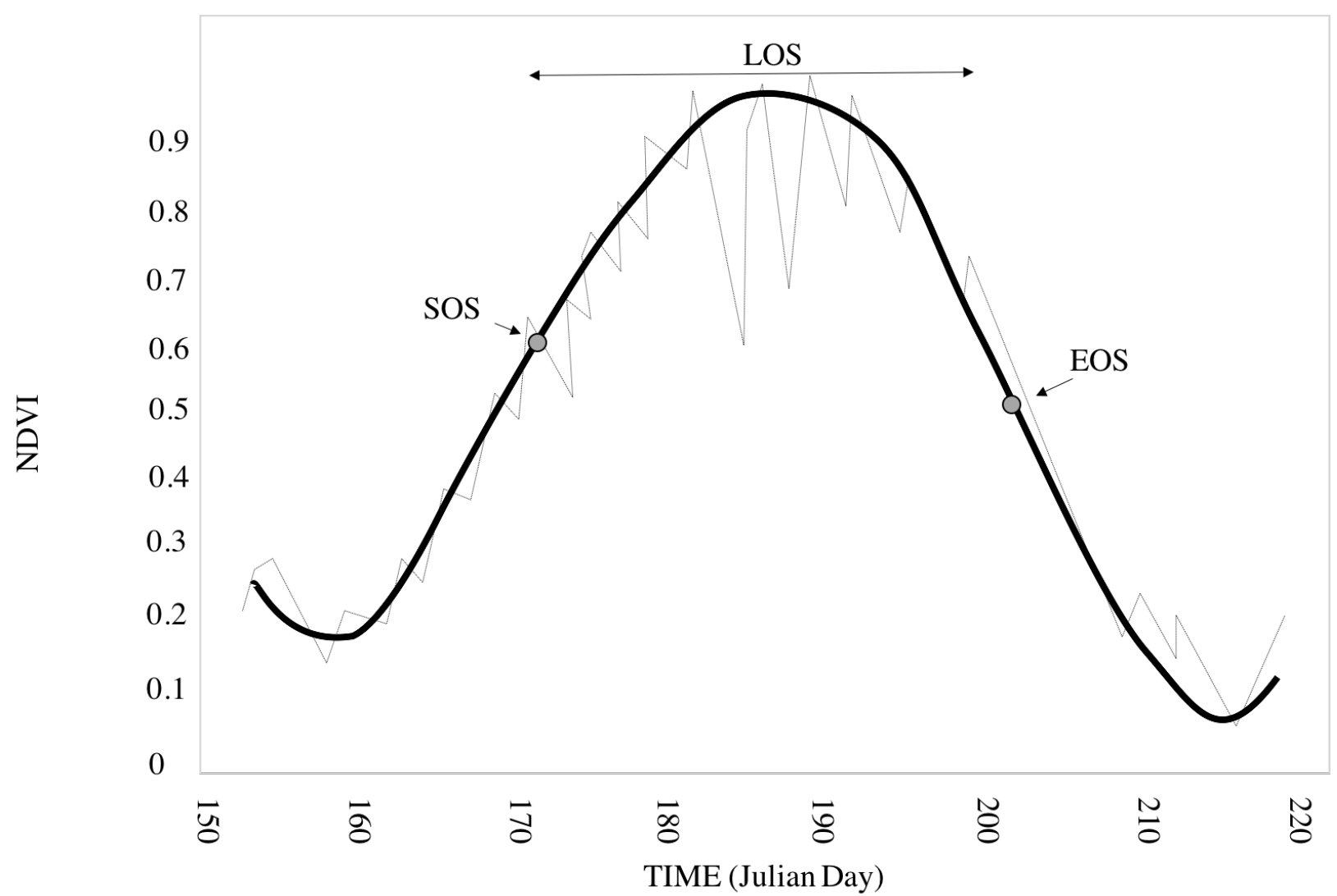

Fig 2.3 Figure depicting the process for extracting phenology variables from time series of NDVI data using the program TIMESAT. Gray lines represent NDVI data, the black line represents the smoothed timesat vegetation signal, the gray dots represent $50 \%$ canopy at start (SOS) and end of season (EOS), LOS represents the difference between EOS and SOS. 


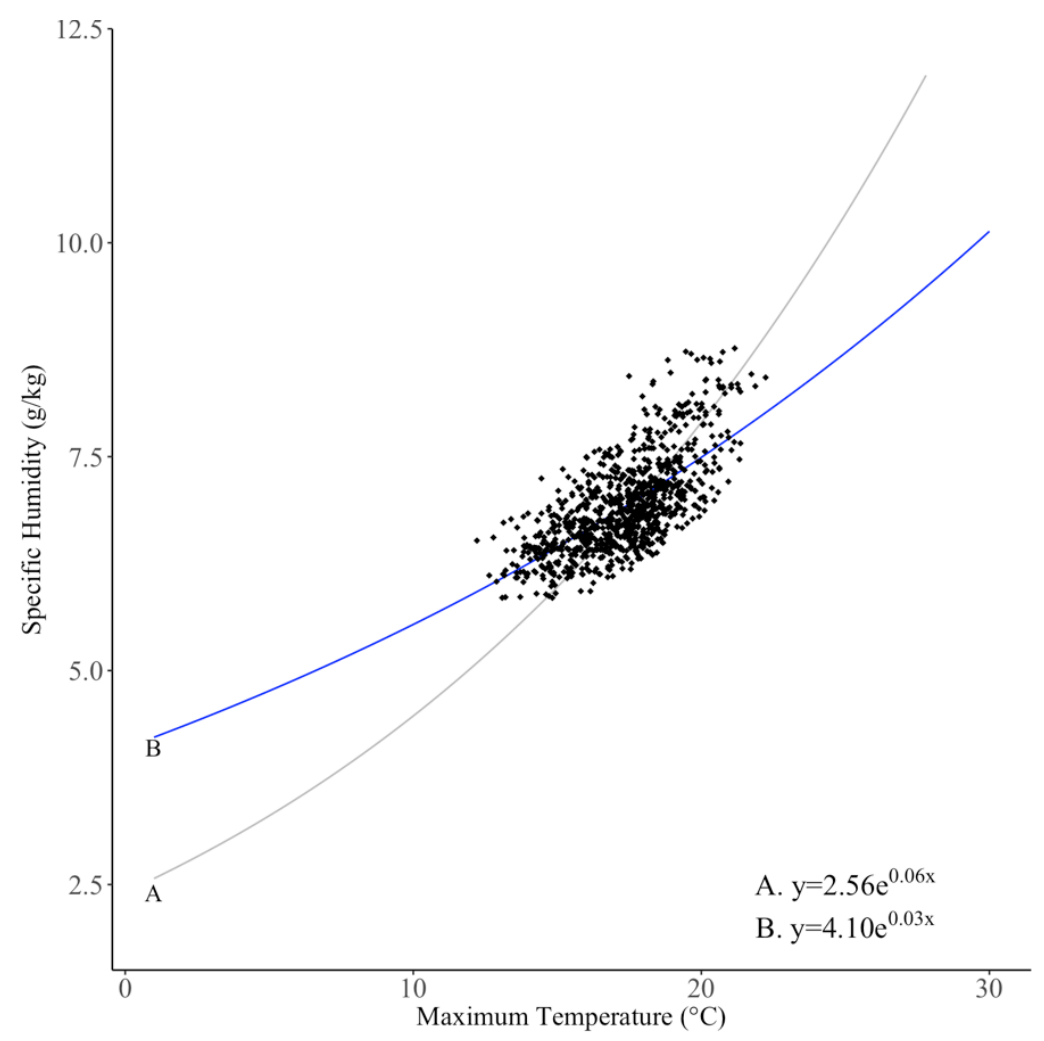

Fig 2.4 Exponential relationship between long-term (1982-2012) annual temperature and specific humidity for 31 watersheds located in the central Appalachian Mountains region. The relationship is exponential, following the theoretical Clausius-Clapeyron relationship (Held and Soden 2006). The relationship states that atmospheric water vapor will exponentially increase with air temperature by $3.4 \%$ to $7 \% /{ }^{\circ} \mathrm{K}$ (or a slope of $2.45 \mathrm{e}^{0.06}$ ) (Held and Soden 2000), though the observed relationship has a slope $\left(y=4.095 \mathrm{e}^{0.03}\right)$ closer to the lower end of the rates proposed $\left(3.4 \% /{ }^{\circ} \mathrm{K}\right.$ ) (Allen and Ingram 2002$)$ 


\section{SUPPLEMENTAL MATERIAL}

S 1: Table of the $31 \mathrm{HCDN}$ watersheds used to study climate and growing season changes in the central Appalachian Region. Study watershed identifiers uniquely classify USGS gauging stations used in this study and corresponds to the Identifier in Figure 1. Station number and station name refer to USGS stream gauge identifiers, and area refers to area upstream of the USGS gauge.

\begin{tabular}{|c|c|c|c|c|}
\hline $\begin{array}{l}\text { Watershed } \\
\text { and Basin } \\
\text { Identifier }\end{array}$ & Basin & $\begin{array}{l}\text { Station } \\
\text { Number } \\
\end{array}$ & Station Name & $\begin{array}{l}\text { Area } \\
\left(\mathrm{km}^{2}\right)\end{array}$ \\
\hline $1 \mathrm{M}$ & Monongahela & 3078000 & Casselman River at Grantsville, MD & 163 \\
\hline $2 \mathrm{M}$ & Monongahela & 3061000 & West Fork River at Enterprise, WV & 1966 \\
\hline $3 \mathrm{M}$ & Monongahela & 3075500 & Youghiogheny River near Oakland, MD & 347 \\
\hline $4 \mathrm{M}$ & Monongahela & 3080000 & Laurel Hill Creek at Ursina, PA & 313 \\
\hline $5 \mathrm{M}$ & Monongahela & 3069500 & Cheat River near Parsons, WV & 1860 \\
\hline 10 & Ohio & 3102500 & Little Shenango River at Greenville, PA & 269 \\
\hline $2 \mathrm{O}$ & Ohio & 3109500 & Little Beaver Creek near East Liverpool, OH & 1285 \\
\hline $7 \mathrm{~K}$ & Kanawha & 3175500 & Wolf Creek near Narrows, VA & 578 \\
\hline $1 \mathrm{~K}$ & Kanawha & 3180500 & Greenbrier River at Durbin, WV & 344 \\
\hline $2 \mathrm{~K}$ & Kanawha & 3186500 & Williams River at Dyer, WV & 332 \\
\hline $3 \mathrm{~K}$ & Kanawha & 3187500 & Cranberry River near Richwood, WV & 208 \\
\hline $4 \mathrm{~K}$ & Kanawha & 3198500 & Big Coal River at Ashford, WV & 1013 \\
\hline $5 \mathrm{~K}$ & Kanawha & 3179000 & Bluestone River at Durbin, WV & 1020 \\
\hline $6 \mathrm{~K}$ & Kanawha & 3183500 & Greenbrier River at Alderson, WV & 3533 \\
\hline $1 \mathrm{~T}$ & Tennessee & 348800 & North Fork Holston River near Saltsville, VA & 575 \\
\hline $2 \mathrm{~T}$ & Tennessee & 3528000 & Clinch River above Tazewell, TN & 3818 \\
\hline $3 \mathrm{~T}$ & Tennessee & 3497300 & Little River above Townsend, TN & 275 \\
\hline $4 \mathrm{~T}$ & Tennessee & 3500000 & Little Tennessee River near Pretniss, NC & 363 \\
\hline 1P & Potomac & 1601500 & Wills Creek near Cumberland, MD & 640 \\
\hline $2 \mathrm{P}$ & Potomac & 1610000 & Pototmac River near Great Cacapon, WV & 8052 \\
\hline $3 \mathrm{P}$ & Potomac & 1611500 & Cacapon River near Great Cacapon, WV & 1753 \\
\hline $4 \mathrm{P}$ & Potomac & 1604500 & Patterson Creek near Headsville, VA & 567 \\
\hline $5 \mathrm{P}$ & Potomac & 1643500 & Bennett Creek at Park Mills, MD & 163 \\
\hline $6 \mathrm{P}$ & Potomac & 1608500 & South Branch Potoamc River near Springfield, WV & 3810 \\
\hline $7 \mathrm{P}$ & Potomac & 1614500 & Conococheague Creek and Fairview, MD & 1279 \\
\hline $8 \mathrm{P}$ & Potomac & 1617800 & Marsh Run at Grimes, MD & 49 \\
\hline 9P & Potomac & 1595000 & North Branch Potomac River at Steyer, MD & 189 \\
\hline $10 \mathrm{P}$ & Potomac & 1637500 & Catoctin Creek near Middletown, MD & 173 \\
\hline $11 \mathrm{P}$ & Potomac & 1644000 & Goose Creek near Leesburg, VA & 860 \\
\hline $12 \mathrm{P}$ & Potomac & 1632000 & North Fork Shenandoah River at Cootes Store, VA & 544 \\
\hline $13 \mathrm{P}$ & Potomac & 1634500 & Cedar Creek near Winchester, VA & 1989 \\
\hline
\end{tabular}


S 2: Climate, hydrology, and phenological datasets used in this study.

\begin{tabular}{|c|c|c|c|c|c|}
\hline Variable & Dataset & $\begin{array}{l}\text { Temporal } \\
\text { Range }\end{array}$ & $\begin{array}{l}\text { Spatial } \\
\text { Resolution }\end{array}$ & Units & References \\
\hline & $\begin{array}{l}\text { GIMMS } \\
\text { NOAA } \\
\text { AVHRR }\end{array}$ & $1981-2000$ & $\sim 8 \mathrm{~km} \times 8 \mathrm{~km}$ & days & $\begin{array}{l}\text { Tucker et al. } \\
\text { (2005) }\end{array}$ \\
\hline $\begin{array}{l}\text { Normalized Difference } \\
\text { Vegetation Index (NDVI) }\end{array}$ & $\begin{array}{l}\text { NASA } \\
\text { MODIS }\end{array}$ & $2000-2012$ & $250 \mathrm{~m} \times 250 \mathrm{~m}$ & days & $\begin{array}{l}\text { Huete et al. } \\
\text { (2002) }\end{array}$ \\
\hline $\begin{array}{l}\text { Maximum and minimum } \\
\text { Temperature }\end{array}$ & MetData & $1979-2015$ & 4-km by 4-km & & \\
\hline Precipitation & MetData & 1979-2015 & 4-km by 4-km & $\begin{array}{l}{ }^{\circ} \mathrm{C} \\
\mathrm{mm}\end{array}$ & \\
\hline Potential evapotranspiration & MetData & 1979-2015 & 4-km by $4-\mathrm{km}$ & $\mathrm{mm}$ & \\
\hline $\begin{array}{l}\text { Maximum and minimum } \\
\text { relative humidity }\end{array}$ & MetData & 1979-2015 & 4-km by $4-\mathrm{km}$ & $\%$ & $\begin{array}{l}\text { Abatzoglou } \\
(2013)\end{array}$ \\
\hline Specific humidity & MetData & 1979-2015 & 4-km by 4-km & $\mathrm{g} / \mathrm{kg}$ & \\
\hline Solar radiation & MetData & $1979-2015$ & 4-km by $4-\mathrm{km}$ & Watts $/ \mathrm{m}^{2}$ & \\
\hline Wind direction & MetData & 1979-2015 & 4-km by 4-km & $\begin{array}{l}\text { degrees } \\
\text { clockwise } \\
\text { from north }\end{array}$ & \\
\hline $\begin{array}{l}\text { Vapor pressure deficit } \\
\text { Dew point temperature }\end{array}$ & $\begin{array}{l}\text { PRISM } \\
\text { PRISM }\end{array}$ & $\begin{array}{l}1979-2015 \\
1979-2016\end{array}$ & $\begin{array}{l}4-\mathrm{km} \text { by } 4-\mathrm{km} \\
4-\mathrm{km} \text { by } 4-\mathrm{km}\end{array}$ & $\begin{array}{l}\mathrm{hPa} \\
{ }^{\circ} \mathrm{C}\end{array}$ & $\begin{array}{l}\text { Daly et al. } \\
\text { (1997) }\end{array}$ \\
\hline $\begin{array}{l}\text { Streamflow/Runoff } \\
\text { Actual evapotranspiration }\end{array}$ & $\begin{array}{l}\text { USGS HCDN } \\
\text { N/A }\end{array}$ & $\begin{array}{l}1982-2012 \\
1982-2012 \\
\end{array}$ & $\begin{array}{l}\text { N/A } \\
\text { N/A }\end{array}$ & $\begin{array}{l}\mathrm{mm} \\
\mathrm{mm}\end{array}$ & $\begin{array}{l}\text { Slack et al. } \\
(1992) \\
\text { N/A }\end{array}$ \\
\hline
\end{tabular}


S 3: Mann Kendal trend table and total change over 31 years for the 31 watersheds in the central Appalachian region. Watershed Identifiers represents each watershed within the five basins, shown in Figure 1. Station number and station name refer to USGS stream gauge identifiers. Bold represents significance at the 0.05 level and bold+italics represents significance at the 0.01 level.

\begin{tabular}{|c|c|c|c|c|c|c|c|c|c|}
\hline $\begin{array}{l}\text { USGS } \\
\text { gageID }\end{array}$ & $\begin{array}{l}\text { DPT } \\
(\mathrm{C})\end{array}$ & $\begin{array}{l}\text { Tmin } \\
(\mathrm{C})\end{array}$ & $\begin{array}{l}\text { Prec. } \\
(\mathrm{mm})\end{array}$ & $\mathrm{Q}(\mathrm{mm})$ & $\begin{array}{l}\text { Rhn_mi } \\
\text { n. }(\%)\end{array}$ & $\begin{array}{l}\text { PET } \\
(\mathrm{mm})\end{array}$ & $\begin{array}{l}\text { EOS } \\
\text { (days) }\end{array}$ & $\begin{array}{l}\begin{array}{l}\text { SOS } \\
\text { (days) }\end{array} \\
\end{array}$ & $\begin{array}{l}\text { Vpdmin } \\
\text { (hPA) }\end{array}$ \\
\hline 3061000 & 0.38 & 0.21 & 63.27 & -42.44 & 0.04 & 51.83 & 10.54 & -7.69 & 0.00 \\
\hline 3069500 & 0.24 & 0.22 & 36.57 & 31.15 & 0.21 & 42.15 & 14.88 & -12.68 & 0.00 \\
\hline 3075500 & 0.22 & 0.05 & 61.60 & -17.28 & 1.16 & 12.40 & 10.23 & -14.39 & -0.01 \\
\hline 3078000 & 0.18 & 0.22 & 13.92 & 61.63 & -0.17 & 48.47 & 11.47 & -7.85 & -0.01 \\
\hline 3080000 & 0.30 & 0.24 & 15.90 & 76.72 & -0.01 & 49.11 & 12.09 & -8.15 & 0.00 \\
\hline 3102500 & 0.39 & 0.41 & 57.93 & 121.39 & 1.60 & 33.55 & 12.4 & -7.31 & -0.01 \\
\hline 3109500 & 0.33 & 0.32 & 79.04 & 76.40 & 1.30 & 54.74 & 11.47 & -7.94 & -0.01 \\
\hline 3175500 & 0.18 & 0.07 & 26.92 & 1.12 & 0.60 & 31.45 & 8.06 & -5.87 & 0.00 \\
\hline 3179000 & 0.13 & 0.17 & 66.06 & 7.80 & 0.20 & 39.07 & 11.78 & -7.91 & 0.01 \\
\hline 3180500 & 0.43 & 0.21 & -8.30 & -37.24 & 0.97 & 8.30 & 0 & -5.17 & 0.00 \\
\hline 3183500 & 0.38 & 0.13 & 4.95 & -50.36 & -0.53 & 40.84 & 9.92 & -4.69 & 0.00 \\
\hline 3186500 & 0.37 & 0.25 & 88.21 & -25.34 & 2.28 & 10.43 & 8.99 & -5.68 & 0.00 \\
\hline 3187500 & 0.44 & 0.21 & 14.25 & -9.79 & 0.00 & 42.00 & 10.23 & -9.12 & 0.00 \\
\hline 3198500 & 0.39 & 0.24 & 112.61 & 25.33 & 2.13 & 29.96 & 12.09 & -11.81 & -0.01 \\
\hline 3488000 & 0.46 & 0.17 & 81.37 & -5.43 & 2.62 & 6.39 & 8.68 & -6.82 & 0.00 \\
\hline 3497300 & 0.29 & 0.21 & 54.63 & -28.76 & 0.00 & 41.56 & 8.37 & -6.33 & 0.00 \\
\hline 3500000 & 0.07 & 0.15 & -168.48 & -76.64 & 0.31 & 37.81 & 8.99 & -4.65 & 0.01 \\
\hline 3528000 & 0.23 & 0.23 & 85.42 & -1.00 & 0.65 & 57.55 & 7.44 & -4.77 & 0.01 \\
\hline 1595000 & 0.41 & 0.14 & 11.74 & 5.60 & -0.84 & 46.78 & 13.02 & -5.50 & -0.01 \\
\hline 1601500 & 0.46 & 0.25 & 53.09 & -28.89 & -0.94 & 64.92 & 13.95 & -9.69 & -0.01 \\
\hline 1604500 & 0.37 & 0.15 & 40.71 & -8.22 & -0.25 & 48.34 & 15.19 & -10.03 & -0.01 \\
\hline 1608500 & 0.46 & 0.20 & 19.22 & -1.24 & -0.39 & 49.07 & 13.95 & -10.52 & -0.01 \\
\hline 1610000 & 0.48 & 0.23 & 25.50 & -18.24 & -0.66 & 53.92 & 10.85 & -8.88 & -0.01 \\
\hline 1611500 & 0.42 & 0.26 & 44.94 & 11.50 & 0.03 & 52.54 & 15.5 & -5.17 & 0.00 \\
\hline 1614500 & 0.53 & 0.22 & 32.44 & 101.04 & 0.04 & 49.31 & 15.5 & -6.84 & -0.01 \\
\hline 1617800 & 0.38 & 0.24 & 55.01 & 52.30 & 0.32 & 59.14 & 13.95 & -7.53 & 0.00 \\
\hline 1632000 & 0.50 & 0.12 & -7.74 & 6.99 & -0.34 & 29.10 & 10.85 & -4.04 & -0.01 \\
\hline 1634500 & 0.68 & 0.24 & -7.99 & -68.47 & 0.10 & 38.69 & 11.78 & -21.18 & -0.01 \\
\hline 1637500 & 0.38 & 0.14 & 48.22 & 38.58 & -0.09 & 60.82 & 13.64 & -7.18 & -0.01 \\
\hline 1643500 & 0.37 & 0.12 & 37.78 & 24.26 & 0.22 & 53.59 & 12.4 & -3.95 & -0.02 \\
\hline 1644000 & 0.56 & 0.21 & 8.20 & -40.30 & 0.16 & 52.52 & -6.46 & - & -0.02 \\
\hline average & 0.4 & 0.2 & 33.8 & 5.9 & 0.3 & 42.3 & 10.7 & -16.3 & 0.0 \\
\hline
\end{tabular}


S 4: Factor loadings for the Principle Component Analysis used to reduce dimensionality of growing season length variables. Growing season length related variables with Eigen vectors $>1$ and factor loadings significantly contributing (i.e. factor loadings rounding to $\geq|0.4|$ ) are shown.

$\begin{array}{lllll}\text { Loadings: } & \text { Comp } 1 & \text { Comp } 2 & \text { Comp } 3 & \text { Comp } 4\end{array}$

\begin{tabular}{|c|c|c|c|c|}
\hline tmax & -0.38 & & & \\
\hline $\mathrm{sph}$ & & -0.45 & & \\
\hline $\operatorname{rmax}$ & & -0.37 & & -0.46 \\
\hline $\mathrm{P}$ & & & & 0.48 \\
\hline th & & & -0.57 & 0.4 \\
\hline vs & & & -0.49 & \\
\hline srad & & & -0.44 & \\
\hline rmin & & & & \\
\hline vpdmin & & & & 0.4 \\
\hline Q & & & & \\
\hline DPT & & -0.373 & & \\
\hline vpdmax & & & & \\
\hline tmin & -0.35 & & & \\
\hline PET & -0.36 & & & \\
\hline
\end{tabular}

maximum temperature [tmax], specific humidity [sph], maximum relative humidity [rmax], precipitation [P], wind direction [th], wind speed [vs], solar radiation [srad], minimum relative humidity [rmin], minimum vapor pressure deficit [vpdmin], runoff [Q], dew pressure temperature [DPT], maximum vapor pressure deficit [vpdmax], annual minimum temperature [tmin], potential evapotranspiration [PET] 
S 5: Best supported mixed effects model parameter estimates based on PCA for identifying important climatic variables effecting mean annual growing season change over the 31 watersheds evaluated in this study.

\begin{tabular}{|c|c|c|c|c|c|c|}
\hline Parameters & Variance & SD & Estimate & $\mathrm{SE}$ & t-value & p-value \\
\hline \multicolumn{7}{|l|}{ Fixed Effects } \\
\hline Intercept & - & - & 179.4 & 1.7 & 104.6 & $<0.001$ \\
\hline $\operatorname{tmax}$ & - & - & 3.7 & 0.9 & 4.0 & 0.008 \\
\hline vpdmin & - & - & -0.7 & 33.0 & -2.0 & 0.034 \\
\hline th & - & - & -1.3 & 0.6 & -2.200 & 0.024 \\
\hline vs & - & - & 2.5 & 0.9 & 2.3 & 0.020 \\
\hline tmax:vpdmin & - & - & -0.6 & 0.3 & 1.9 & 0.040 \\
\hline rmax:sph & - & - & -0.7 & 0.3 & -2.2 & 0.024 \\
\hline vpdmin:vs & - & - & 0.8 & 0.3 & 2.4 & 0.017 \\
\hline \multicolumn{7}{|l|}{ Random Effects } \\
\hline year & 66.1 & 8133.0 & - & - & - & - \\
\hline site & 21.2 & 4.6 & - & - & - & - \\
\hline rmax|year & 2.1 & 1.5 & - & - & - & - \\
\hline th|year & 2.7 & 1.6 & - & - & - & - \\
\hline srad|year & & 3.2 & 1.8 & - & - & - \\
\hline vs|year & & 1.5 & 1.2 & - & - & - \\
\hline
\end{tabular}

$\mathrm{SD}=$ standard deviation; $\mathrm{SE}=$ standard error; tmax= maximum temperature; vpdmin= minimum vapor pressure deficit; th= wind direction; $v s=$ wind speed; $\mathrm{sph}=$ specific humidity; $\mathrm{rmax}=$ maximum relative humidity; srad=solar radiation;. The interactions between fixed effects are represented as a colon (e.g. :) and the interaction between a fixed effect and a random effect is represented as a vertical bar (e.g. $\mid)$

Model: tmax + vpdmin + th + vs $+1 \mid$ site $+1 \mid$ year + rmax|year + th|year + srad|year + vs|year + tmax $\mid$ vpdmin $+\operatorname{rmax} \mid s p h+$ vpdmin|vs 
S 6: Factor Loadings for the Principle Component Analysis used to reduce dimensionality of evapotranspiration variables. Evapotranspiration related variables with Eigen vectors $>1$ and factor loadings significantly contributing (i.e. factor loadings rounding to $\geq|0.4|$ ) are shown.

\begin{tabular}{lrrrr}
\hline Loading & Comp 1 & Comp 2 & Comp 3 & Comp 4 \\
\hline \hline tmax & -0.37 & & & \\
sph & & -0.39 & & \\
rmax & & -0.35 & & \\
vpdmin & & & & -0.56 \\
th & & & & -0.35 \\
srad & & & & \\
Q & & & & \\
DPT & & & & \\
vpdmax & & & & \\
tmin & & & & \\
PET & -0.35 & & & \\
P & & & & \\
vs & & & & \\
rmin & & & -0.35 & \\
SOS & & & & \\
EOS & & & -0.52 & \\
LOS & & & & \\
\hline
\end{tabular}

maximum temperature [tmax], specific humidity [sph], maximum relative humidity [rmax], minimum vapor pressure deficit [vpdmin], wind direction [th], solar radiation [srad], runoff [Q], dew pressure temperature [DPT], maximum vapor pressure deficit [vpdmax], minimum temperature [tmin], potential evapotranspiration [PET], precipitation [P], wind speed [vs], minimum relative humidity [rmin], start of season [SOS], end of season [EOS], length of season [LOS] 
S 7: Best supported mixed effects model parameter estimates based on PCA for identifying the interaction of growing season length and mean annual evapotranspiration over the 31 watersheds evaluated in this study.

\begin{tabular}{|c|c|c|c|c|c|c|}
\hline Parameters & Variance & $\begin{array}{l}\text { std. } \\
\text { deviation }\end{array}$ & Estimate & Std. Error & t-value & p-value \\
\hline \multicolumn{7}{|l|}{ Fixed Effects } \\
\hline Intercept & - & - & 604.16 & 37.09 & 16.29 & $<0.0001$ \\
\hline $\operatorname{tmax}$ & - & - & 16.46 & 19.5 & 0.84 & $>0.1$ \\
\hline $\operatorname{rmax}$ & - & - & 15.96 & 9.66 & 1.65 & 0.05 \\
\hline sph & - & - & -7.55 & 7.36 & -1.03 & $>0.1$ \\
\hline vs & - & - & 4.59 & 21.69 & 0.212 & $>0.1$ \\
\hline th & - & - & 0.41 & 5.18 & 0.081 & $>0.1$ \\
\hline srad & - & - & 6.46 & 10.69 & 0.604 & $>0.1$ \\
\hline tmax:LOS & - & - & -2.63 & 7.69 & -0.342 & $>0.1$ \\
\hline rmax:LOS & - & - & 3.54 & 5.03 & 0.704 & $>0.1$ \\
\hline sph:LOS & - & - & -6.97 & 6.49 & -1.07 & $>0.1$ \\
\hline vs:LOS & - & - & -6.01 & 5.911 & -1.016 & $>0.1$ \\
\hline th:LOS & - & - & -0.5 & 5.26 & -0.096 & $>0.1$ \\
\hline srad:LOS & - & - & -0.09 & 5.6 & -0.016 & $>0.1$ \\
\hline \multicolumn{7}{|l|}{ Random Effects } \\
\hline year & 1194 & 95.55 & - & - & - & - \\
\hline site & 38554 & 196.35 & - & - & - & - \\
\hline vs|site & 2540 & 50.4 & - & - & - & - \\
\hline tmax|site & 3958 & 62.91 & - & - & - & - \\
\hline
\end{tabular}

$\mathrm{SD}=$ standard deviation; $\mathrm{SE}=$ standard error; $\mathrm{tmax}=$ maximum temperature; vpdmin $=$ minimum vapor pressure deficit; $\mathrm{sph}=$ specific humidity; vs=wind speed; LOS= length of season;. The interactions between fixed effects are represented as a colon (e.g. :) and the interaction between a fixed effect and a random effect is represented as a vertical bar (e.g. |)

$$
\text { Model }=\text { tmax }+\operatorname{rmax}+\mathrm{sph}+\mathrm{vs}+\text { th }+\operatorname{srad}+1 \mid \text { site }+1 \mid \text { year }+ \text { vs|sites }+ \text { tmax } \mid \text { sites }+
$$

$\mathrm{LOS}|\operatorname{tmax}+\operatorname{rmax}| \mathrm{LOS}+\operatorname{sph}|\mathrm{LOS}+\mathrm{vs}| \mathrm{LOS}+$ th $|\mathrm{LOS}+\operatorname{srad}| \mathrm{LOS}$ 
Gaertner, B. Zegre, N. Fernandez, R. 2018. Spatial variations in streamflow sensitivity to climate change: Implications for water resources management in the central Appalachian Mountains region, USA. Water.

\begin{abstract}
This study quantified long-term historical and future climate trends, evaluated water balance sensitivity to change, and quantified future runoff for catchments located throughout the central Appalachian Mountains regions of the eastern USA. Long-term historical precipitation (P), potential evapotranspiration (PET), and evapotranspiration (ET) were implemented in a Budykobased sensitivity hydrologic model to determine watershed sensitivity to changing energy and water inputs. Long-term future streamflow was modeled based on derived sensitivity coefficients and future PET and P. The results showed that streamflow sensitivity increased with decreasing precipitation throughout the region. Future runoff is projected to increase between $9-17 \%$ throughout the region, with runoff increasing with increasing $\mathrm{P}$, which generally followed the rain shadow pattern of the prevail westerly winds, with the lowest sensitivity along the Appalachian mountain spine and increasing sensitivity with increasing distance from the mountains. The sensitivity coefficients throughout the regions were also controlled by other climate and landscape characteristics including forest cover, P inputs, and soil moisture holding capacity. Watershed sensitivity and future increasing $\mathrm{P}$ is expected to result in increasing runoff, which has important implications for infrastructure, energy, and ecosystem service supply. We discuss preventative forest management measures to minimize future water resource concerns and maintain stable drinking water supplies to downstream communities.
\end{abstract}

\title{
3.1 INTRODUCTION
}

Forested headwater catchments play a critical role in freshwater provisioning but climate change and human modifications of land cover affect water resources availability by altering the amount of precipitation $(\mathrm{P})$ partitioned into runoff $(\mathrm{Q})$, evapotranspiration (ET), and storage (S) (DeWalle et al. 2000, Post and Jones 2001, Jones and Post 2004, Creed et al. 2011, Creed et al. 2014). Human activities that alter forest cover can complicate, mitigate, and potentially counteract climate change effects on streamflow (Jones 2011, Patterson et al. 2013, Creed et al. 2014), leading to variations in water yield. Changing annual water yields have been observed in 
headwater temperate forest biomes throughout North America (Campbell et al. 2011, Wang and Hejazi 2011, Jones et al. 2012). The effects of climate warming on Q derived from headwater catchments is of great to resource managers and decisions-makers given their importance in provisioning fresh water supplies for downstream population centers (Viviroli and Weingartner 2004, Viviroli et al. 2007). One such headwaters region is the central Appalachian Mountains region located in the eastern United States, an area which provides drinking water resources (Dudley and Stolton 2003) to downstream metropolitan areas such as Washington D.C., Pittsburgh (PA), and Cincinnati (OH). Despite the importance of the central Appalachian region for provisioning fresh water to approximately $9 \%$ of the U.S. population (U.S.CensusBureau 2009), the sensitivity of streamflow (Q) to changes in climate is largely unknown. It is critical to understand the sensitivity of forested catchments to climate change in order to develop policies and practices that ensure future water availability and sustainability (Bates et al. 2008).

Streamflow from forested catchments is sensitive to changes that alter the proportion of $\mathrm{P}$ partitioned into Q and ET such as land use/land cover change, changes in growing season length, and climate change (Campbell et al. 2011, Caldwell et al. 2012). Human activities such as forest harvesting and conversion of forests to agriculture can increase runoff by reducing canopy interception and ET (Eagleson 1978, Gardner 1983, Canadell et al. 1996, Jones and Post 2004). On the other hand, increases in forest growing season length due a warming climate can increase ET and subsequently decrease Q. In the central Appalachian region, for example, growing season length has increased on average by 22 days since 1980 (Gaertner et al. 2019), increasing ET by 0.5-4.3 mm per year (Hwang et al. 2014, Hwang et al. 2018). Increased ET due to a longer growing season length has the potential to reduce streamflow (Jones et al. 2012, Patterson et al. 2013, Kim et al. 2018). Globally, increasing air temperatures have resulted in a greater ET and P through intensification of the water cycle (Huntington 2010), leading to humid regions becoming wetter and arid regions becoming drier (Chou et al. 2009). In some regions of the USA, increases in Q have followed increases in P (Lins and Slack 1999, Krakauer and Fung 2008) while other regions throughout the nation have experienced greater occurrences of drought (Andreadis and Lettenmaier 2006).

Approaches for analyzing the impacts of climate change and land use on Q generally fall into three categories: empirical statistics, climate elasticity models that include Budyko-based approaches, and hydrologic modeling. Empirical statistics establish a relationship between 
climate variable(s) of interest, usually $\mathrm{P}$ and $\mathrm{Q}$, thus requiring long term hydro-meteorological data to capture long-term variations (Wu et al. 2017). Approaches include regression, time series/trend analyses, or the double-mass curve method (Gao et al. 2011, Zhao et al. 2014). Empirical models often are the easiest to implement but do not necessary produce reliable streamflow estimates (Wu et al. 2017). Elasticity models have an intermediate model complexity and are frequently based on the Budyko framework (Budyko 1961, Schaake 1990, Sankarasubramanian and Vogel 2003). The Budyko framework uses physically based principles to quantify the relationship between P, ET, and PET to describe how catchments partition P into Q and E. Budyko approaches require long-term historical P, ET, and PET data and often include a parameter to account for landscape controls on ET (Fu 1981, Choudhury 1999, Padrón et al. 2017). Hydrologic modelling uses complex hydrologic models often forced with climate, land cover, soils, and topography data to simulate the hydrologic cycle. Application of hydrologic modelling is most limiting given the large data requirements, calibration, and validation. Elasticity and hydrologic modelling methods generally produce similar estimates to observed streamflow (Roderick and Farquhar 2011, Wang 2014)

Budyko-based approaches are simple, have few data requirements, and explicitly consider large-scale drivers of the water and energy balance. The Budyko framework (Budyko 1974, Milly 1994, Sankarasubramanian et al. 2001) implies that the long-term average ratio of ET to mean annual $\mathrm{P}$ is primarily controlled by the long-term average ratio of maximum $\mathrm{E}$ (potential E) to mean annual P. Budyko (1974) showed that ET is limited by energy demand and water availability. The relationship is displayed on a theoretical curve in Budyko space as the ratio of long-term potential evapotranspiration to precipitation (PET/P, dryness index), versus the ratio of long-term actual evapotranspiration (ET/P, evaporative index) to precipitation.

Catchments with $\mathrm{PET} / \mathrm{P}>1$ are categorized as being water limited, while basins with $\mathrm{PET} / \mathrm{P}<1$ are classified as energy limited (Figure 2).

Budyko-based hydrology models are frequently used to for elasticity studies that quantify the effects of non-climatic factors (Wang 2014). There are two predominant approaches to elasticity models. The first quantifies relative streamflow change in response to climate and human change by determining the relationship between long-term average PET, P, ET, and Q (Sankarasubramanian et al. 2001, Tomer and Schilling 2009). The second quantifies streamflow response to changing climate and land use based on a step shift in climate and human activity 
(Roderick and Farquhar 2011, Wang and Hejazi 2011, Zeng et al. 2014). The second technique has several applications. First, it has been used to quantify the proportion of streamflow change due to climate and human factors (Patterson et al. 2013). Second it has been used to quantify the sensitivity of streamflow based on a shift in long-term climate (P, PET) and the land use parameter, n (Ma et al. 2010, Roderick and Farquhar 2011). The sensitivity method can also be used to assess future streamflow based on climate projections (Roderick and Farquhar 2011).

Here we use Roderick and Farquhar (2011) to (1) assess the sensitivity of Q from relatively undisturbed forested catchment in the central Appalachian region and (2) quantify future streamflow response to future changes in climate. Specifically, we quantified spatial and temporal sensitivity to historic and future changes in changing water and energy availability. Understanding the sensitivity of streamflow of the region to future climatic changes can provide valuable insight into forest and water resources management in order to protect the reliability of fresh water resources for downstream population centers. Our objectives for this study were to:

1. Quantify long-term historic and future climate and water balance changes throughout the central Appalachian Mountains region.

2. Assess historical streamflow sensitivity to changes in climate and catchment factors

3. Quantify streamflow sensitivity to future changes in climate

\subsection{METHODOLOGY}

\subsubsection{Data}

Mean daily streamflow data was extracted for 31 catchments located across 5 dominant river basins in the central Appalachian Mountains region (Figure 1): the Monongahela, Upper Ohio, Kanawha, and Tennessee River, which drain west to the Mississippi River and Gulf of Mexico, and the Potomac River, which drains east to Washington D.C. and the Chesapeake Bay. This approximately $125,000 \mathrm{~km}^{2}$ region is greater than $80 \%$ forested (Slayer 2014) and spans 5 states: West Virginia (WV), parts of Virginia (VA), North Carolina (NC), Maryland (MD), and Tennessee (TN) (ARC 1970). The catchments examined in this study were selected based on their inclusion in the U.S. Geological Survey Hydro-Climatic Data Network (HCDN) (Slack and Landwehr 1992) which consists of Q station data for minimally impacted catchments ( $<10 \%$ human influence such as reservoirs, diversion, land use change, or severe ground-water pumping) catchments (J.R. Slack 2006). The $31 \mathrm{HCDN}$ catchments cover approximately $39 \%$ of 
the total area of the five river basins, with seven catchments in the Kanawha basin, five watersheds in the Monongahela basin, two watersheds in the Ohio basin, thirteen watersheds in the Potomac Basin, and four watersheds in the Tennessee basin (Figure 1). The original HCDN dataset covered the time period of 1974-1988 that was extended by extracting Q data from the USGS historical water dataset (http://waterdata.usgs.gov) from 1965-2005 using the R package Retrieval (RCore 2014). Regional land cover analysis using the most recent (2011) National Land Cover Database (NLCD) (Homer et al. 2015) dataset was used to confirm that the catchments continued to be minimally impacted during the extended analysis period beyond the original NLCD period. Q data were normalized by area, converted to millimeters per year, and averaged to annual values based on the USGS water-year (October 1 - September 31).

Air temperature and $\mathrm{P}$ were extracted from the Multivariate Adaptive Constructed Analogs version 2 (MACAv2-METDATA) dataset (Abatzoglou and Brown 2012). MACA data are downscaled and bias corrected from Global Climate Models (GCMs) to a higher spatial resolution of $4 \mathrm{~km}^{2}$ using a non-parametric-quantile-mapping and constructed Analogs method (see Abatzoglou and Brown (2012) and Fernandez and Zegre (2019) (in review), for more information). In this study, 17 different GCM models included in the MACA dataset were used to create ensemble climate data for the historical (1965-2005) period and a future (2070-2099) period using RCP 4.5 and RCP 8.5 (Meinshausen et al. 2011). RCP 4.5 represents a lower greenhouse gas emission that peaks in 2040 then declines (Meinshausen et al. 2011), while in RCP 8.5, greenhouse gas emissions continue to rise throughout the $21^{\text {st }}$ century. Historical and future potential evapotranspiration (PET) was calculated for the region by (Fernandez and Zegre 2019) using Penman-Montieth (Penman 1948) forced with the regional MACA dataset.

ET was estimated using the water year annual balance $\mathrm{ET}=\mathrm{P}-\mathrm{Q}+\Delta \mathrm{S}$, where $\mathrm{P}$ is long-term precipitation, $\mathrm{Q}$ is long-term streamflow, and $\Delta \mathrm{S}$ is watershed storage, which is assumed to approach zero over a long time period. The historical data period was split into two 20 -year time periods with equal intervals; 1965-1985 and 1985-2005.

\subsubsection{Quantifying climate and water balance changes}

The Mann-Kendall statistical test, commonly used in hydrometeorological studies (Yue et al. 2002) was used to assess monotonic trends in historical annual climate (PET) and water balance components (P, ET,Q) using the R package trend (RCore 2014). The slope of trends 
were calculated using the Sen slope (Sen 1968), which is calculated as the median of all possible pair wise slopes. Statistical significance was assessed at $\alpha=0.10$.

\section{Quantifying streamflow sensitivity to climate change and catchment parameters}

Streamflow sensitivity to climate change and landscape characteristics was calculated following Choudhury (1999)'s realization of the Budyko equation:

$$
E T=\frac{E T * P E T}{\left(P^{n}+P E T^{n}\right)^{1 / n}} \quad \text { Equation } 1
$$

where ET is long-term evapotranspiration, PET is long-term potential evapotranspiration, $P$ is long-term precipitation ( $\mathrm{mm}$ ), and $n$ is a dimensionless catchment-specific parameter that modifies the partitioning of $\mathrm{P}$ between $\mathrm{Q}$ and $\mathrm{E}$ (Figure 2). The n-parameter is based on unique watershed characteristics such as soil properties (Donohue et al. 2012), vegetation cover (Li et al. 2013), and slope (Xu et al. 2013, Padrón et al. 2017) (Figure 2).

The formulation of equation 1 was used to quantify the change in $\mathrm{E}$ due to changes in climate (P, PET) and catchment properties (n) Roderick and Farquhar (2011).

$$
d E=\frac{\partial E}{\partial P} d P+\frac{\partial E}{\partial P E T} d P E T+\frac{\partial E}{\partial n} d n
$$

Where $\partial E / \partial P$ represents the theoretical sensitivity of streamflow to changes in precipitation, $\partial E / \partial P E T$ represents the sensitivity of streamflow to changes in energy (PET), and $\partial E / \partial n$ represents the change in $\mathrm{Q}$ following a change in watershed characteristics. An increase in $\partial \mathrm{E} / \partial \mathrm{P}$ will increase $\mathrm{Q}$, while an increase in $\partial \mathrm{E} / \partial \mathrm{PET}$ and $\partial \mathrm{E} / \partial \mathrm{n}$ will decrease $\mathrm{Q}$. For example, if $\partial \mathrm{E} / \partial \mathrm{P}$ is 2.6 , then a $10 \%$ increase in P will yield a $26 \%$ increase in Q (Roderick and Farquhar 2011).

The respective partial differentials are given by $3 a-3 c$, which provide a basic understanding of how changes in climate (P,PET) and land cover (n) affect E.

$$
\frac{\partial E}{\partial P}=\frac{E}{P}\left(\frac{P E T^{n}}{P^{n}+P E T^{n}}\right)
$$

Equation $3 \mathrm{a}$ 


$$
\begin{gathered}
\frac{\partial E}{\partial P E T}=\frac{E}{P E T}\left(\frac{P^{n}}{P^{n}+P E T^{n}}\right) \\
\frac{\partial E}{\partial n}=\frac{E}{n}\left(\frac{\ln \left(P^{n}+P E T^{n}\right)}{n}\right)-\frac{\left(P^{n} \ln P+P E T^{n} \ln P E T\right)}{P^{n}+P E T^{n}}
\end{gathered}
$$

It is assumed that the water balance changes over time are from one steady state to another steady state (Roderick and Farquhar 2011), i.e. that transient changes in storage can be ignored (e.g. Li et al. (2007). Based on this assumption, dQ is calculated by

$$
\mathrm{dQ}=\mathrm{dP}-\mathrm{dE}
$$

Equation 4

By combining Equations 2 and 4, dQ is given by:

$$
d Q=\left(1-\frac{\partial E}{\partial P}\right) d P-\frac{\partial E}{\partial P E T} d P E T-\frac{\partial E}{\partial n} d n
$$

Equation 5

Relative dQ is then solved by:

$$
\frac{d Q}{Q}=\left[\frac{P}{Q}\left(1-\frac{\partial E}{\partial P}\right)\right] \frac{d P}{P}-\left[\frac{P E T}{Q} \frac{\partial E}{\partial P E T}\right] \frac{d P E T}{P E T}-\left[\frac{n}{Q} \frac{\partial E}{\partial n}\right] \frac{d n}{n}
$$

Equation 6

The terms in square brackets are the sensitivity coefficients expressing the effect that changing $\mathrm{P}$ and PET have on relative $\mathrm{Q}$.

\subsubsection{Modeling future streamflow sensitivity}

The sensitivity of future streamflow to future changes in climate was modeled using historical sensitivity coefficients (Eq. 3a, 3b, 3c) and future climate based on ensemble RCP 4.5 and RCP 8.5 data. Future changes in P and PET were calculated relative to the historical period (H):

$$
\begin{aligned}
& \frac{d P}{P} R C P, x=\frac{P_{R C P, x}-P_{H}}{P_{H}} \\
& \frac{d P E T}{P E T} R C P, x=\frac{P E T_{R C P, x}-P E T_{H}}{P E T_{H}}
\end{aligned}
$$

Equation 8

Substituting future values of $\mathrm{P}$ and PET into Equation 5 with the historical sensitivity coefficients for P and PET (Eq. 3a-3c), future dQ was calculated by:

$$
d Q=\left(1-\frac{\partial E}{\partial P}\right) d P_{R C P, x}-\frac{\partial E}{\partial P E T} d P E T_{R C P, x}-\frac{\partial E}{\partial n} d n
$$

where dQ represents future Q change based on watershed sensitivity and future $\mathrm{P}$ and PET under both RCP scenarios. Because our analysis focused on HCDN catchments, we assumed that 
catchment properties (parameter $n$ ) does not change in the future, thereby setting the $n$ sensitivity coefficient and dn to 0 . We recognize that this assumption is likely an oversimplification of future landscape conditions, particularly in light of changes in forest structure, age, productivity, and growing season length (Roman et al. 2015, Caldwell et al. 2016, Hwang et al. 2018, Gaertner et al. 2019) in relatively undisturbed catchments throughout the region. Future analysis should consider $\mathrm{dn}$ to more thoroughly account for ecosystem changes important to the partitioning of $\mathrm{P}$ into $\mathrm{E}$ and $\mathrm{Q}$.

\subsection{RESULTS}

\subsubsection{Climate and water balance changes throughout the central Appalachian Mountains region} 3.3.1.1. [Historic Climate and Water Balance] Long-term average historical annual climate, water balance, and Budyko components from 1965-2015 are shown in Table 1. Long-term average annual $\mathrm{P}$ across catchments ranged from 1001-1700 mm, but no significant trends were detected at either alpha $=0.05$ or alpha $=0.01$ (Table 2). ET across catchments ranged from 114$779 \mathrm{~mm}$ but, similar to P, no significant trends were detected. Long-term average annual PET ranged from 1189-1455 $\mathrm{mm}$ across catchments (Table 1; Figure 4), significantly increasing by between 2-3\% (p-value=0.027). Q ranged from $379-1039 \mathrm{~mm}$ across catchments and, similar to $\mathrm{P}$ and ET, has not changed significantly (Table 2).

\subsubsection{2. [Historical Budyko] All of the study basins were energy-limited, i.e. PET/P $<1$. The} dryness index was greatest in the Potomac (1.34) and lowest for the Monongahela (1.0), with the dryness index equal to 1.2 in other basins (Figure 3). Evaporative index ranged from 0.4 to 0.62 , where the lower values were in the Monongahela, and the higher values in the Potomac. The evaporative index in the other basins ranged from 3.9 (Ohio) to 0.57 in the Kanawha and Tennessee, averaging 0.44 across the region. The $\mathrm{n}$ parameter was greatest for the Potomac (1.8), while the other basins averaged around $\sim 0.9$ (Table 1; Figure 5).

3.3.1.3. [Future climate and Budyko components] Future climate (2015-2099) and trends are shown in Table 3 and 4. Future PET ranged from 1369 - $1628 \mathrm{~mm}$ under the RCP4.5 scenario, increasing by $11-16 \%$ over the historical period. For the RCP 8.5 scenario, PET ranged from $1515-1780 \mathrm{~mm}$, increasing by $20-28 \%$ also increasing over the historical period. Future P under 
the 4.5 scenario ranged from $1018-1813 \mathrm{~mm}$, increasing by 6 to $8 \%$ over historical period. $\mathrm{P}$ under the RCP 8.5 scenario ranged from 1039 to $1805 \mathrm{~mm}$, increasing by 6-12\% over the historic period (Table 4).

Catchments largely will remain energy-limited under future conditions, although increases in energy demand will push three catchments toward water limitation (Table 3), one in the Monongahela basin, the Kanawha basin, and the Tennessee basin.

\subsubsection{Streamflow sensitivity to changes in climate and catchment factors}

Streamflow sensitivity varied across catchments (Table 5). Q sensitivity to $P$ was greatest in the Potomac, averaging 22\% across the Potomac catchments and least in the Monongahela (13.6\%). Q sensitivity to P in the other basins averaged $14.8-16.9 \%$. Q sensitivity to PET was highest in the Potomac basin (12.2\%) and lowest in the Monongahela (3.6\%). The other watersheds ranged from $4.8 \%$ (Kanawha), $6.0 \%$ (Tennessee) to $6.9 \%$ (Ohio). Q sensitivity to land use (n) was highest in the Potomac basin (8.9\%) and lowest in the Monongahela (5.3\%). The other basins ranged from 5.8\% (Tennessee), 6.2\% (Kanawha), and 7.4\% (Ohio).

\subsubsection{Modelling future $Q$ using the results of the sensitivity approach}

Our model predicts the dQ will increase between 9-17\% across the study region (Table 6) based on the RCP 4.5 scenario by the late $21^{\text {st }}$ century. Future runoff is expected to increase the greatest in the Potomac $(17 \%, 70 \mathrm{~mm})$ and least in the Monongahela watershed $9 \%(65 \mathrm{~mm})$ under RCP 4.5. Q in the other basins exhibit an increase between 10-16\% (68-70 $\mathrm{mm})$ in order from Tennessee $(10 \%, 69.6)$, Kanawha (10\%70.3), Ohio (16\%, 68.6).

Under the RCP 8.5 scenario, dQ is predicted to increase between 9-17\% (62 and $70 \mathrm{~mm}$ ), with an overall increase of $14 \%(66 \mathrm{~mm})$. The Monongahela and Tennessee basins are predicted to increase the least under RCP 8.5 by $9 \%(66-69 \mathrm{~mm})$ and the Potomac basin will increase the greatest under the RCP 8.5 scenario by $17 \%(63 \mathrm{~mm})$. The other basins are expected to increase between $10-15 \%$ (66.8 to $69.9 \mathrm{~mm})$ in order from Kanawha $(10 \% ; 68.7)$ and Ohio $(15 \% ; 67.18)$. 


\subsection{DISCUSSION}

\subsubsection{How has climate changed in the central Appalachian Mountains?}

Precipitation is strongly influenced by topography, as greater P occurs on the western facing slopes of the Appalachian Mountains and the eastern slopes receives less P due to orographic effects and the rain shadow (Pitchford et al. 2011, Siler et al. 2013) (Figure 3a). Despite varying precipitation occurring throughout the region, all basins are energy-limited (Figure 3c) with a general surplus of water. P for the region has not changed significantly between 1965 and 2015 despite significant change in nearby regions. For example, the northeast United States, which has similar topography but generally cooler climate than the central Appalachian region, has experienced long-term increasing precipitation (1970-2000) (Hayhoe et al. 2006). The southeast United States has experienced variable precipitation patterns, with both excessive wet and dry years (Ford et al. 2011, Laseter et al. 2012, Patterson et al. 2012). Since our research only evaluated long-term annual trends (1965-2015), it is possible that inter-annual precipitation variations masked long-term monotonic changes. Notwithstanding, future precipitation for the region is expected to increase between $8-10 \%$ by 2100 , which is similar to the $15 \%$ increases predicted for the larger eastern USA (Fernandez and Zegre 2019). Nearby regions of the northeast and southeast US are also expected to experience changes in future $\mathrm{P}$, with P increasing by 3-6\% by 2099 (Hayhoe et al. 2006, Hayhoe et al. 2008, Wu et al. 2012, Fernandez and Zegre 2019).

Increases in PET were found across all catchments examined, indicating that atmospheric demand has increased, likely due to warming (Ford et al. 2011, Pitchford et al. 2011, Laseter et al. 2012, Patterson et al. 2012). PET patterns are mainly driven by energy availability, temperature, and wind movement (Penman 1948). Future PET is expected to continue to increase by $15-26 \%$ throughout the region by 2100 . These trends are similar to the $25 \%$ increase in PET predicted for the larger eastern USA (Fernandez and Zegre 2019).

Interestingly, ET in our study area has not changed significantly from 1965-2015, despite increasing trends in nearby regions in the northeast and southeast United States (Burns et al. 2007, Cruise et al. 2010, Campbell et al. 2011, Feng et al. 2016). That ET did not change in our region could be due to several factors. First, intra-annual variation over our long-term analysis could have dampened monotonic trend analysis. Second, ET processes such as increasing growing season length, greater atmospheric $\mathrm{CO}_{2}$ concentration, and stomatal dynamics related to 
drought stress could have mitigated or counteracted other factors (Idso and Brazel 1984, Roman et al. 2015, Kim et al. 2018). Growing season length has increased in the central Appalachian region by 22 days since 1982 (Gaertner et al. 2019) which results in higher ET (White et al. 1999, Hwang et al. 2014, Hwang et al. 2018). However, higher $\mathrm{CO}_{2}$ concentration could have counteracted this trend by decreasing ET fluxes through increased water use efficiency (Keenan et al. 2013). Tree core and eddy covariance data have shown that higher $\mathrm{CO}_{2}$ concentration reduces the time required for stomatal opening and increases water use efficiency, thereby decreasing ET fluxes (Frank et al. 2015). Similarly, drought stress stomatal dynamics of the vegetation in the central Appalachian Mountains increases water use efficiency and reduces ET fluxes in low soil moisture conditions during peak summer months (Brzostek et al. 2014, Roman et al. 2015). Therefore, while a longer growing season could have increased ET, other variables likely have counteracted the effect and resulted in an insignificant net change in ET despite increasing trends in nearby regions.

\subsubsection{How sensitive are catchments in the central Appalachian Mountains region to climate change?}

The sensitivity approach has been applied in large basins throughout the United States. In water-limited regions of the southwest United States, Q has a higher sensitivity to changes in $\mathrm{P}$ and PET (Sankarasubramanian et al. 2001). Conversely, energy-limited regions such temperate forests of the eastern United States generally have a lower sensitivity to P and PET changes (Sankarasubramanian and Vogel 2003). Catchments with lower sensitivity to changing climate

are generally controlled by climatic and landscape characteristics including higher temperate and coniferous forest cover (Creed et al. 2014), higher precipitation inputs, greater soil moisture holding capacity (Sankarasubramanian and Vogel 2003, Cooper et al. 2018), higher elasticity (Sankarasubramanian et al. 2001), and higher slope (Padrón et al. 2017), making these watersheds more capable of buffering changes in water supply.

Streamflow sensitivity in the central Appalachian region averaged below 2.5, indicating energy limited catchments (Sankarasubramanian and Vogel 2003). The Potomac had the highest sensitivity, with a single catchment with sensitivity of 7.0. Precipitation appears to be the primary driver of catchment sensitivity, with higher precipitation resulting in lower sensitivity (Figure 4). The Monongahela has the greatest $\mathrm{P}$ in the region and the lowest sensitivity. 
Similarly, the high sensitivity coefficient in the Potomac basin is consistent with relatively arid conditions and low precipitation. This precipitation pattern is attributed to the rain shadow effect, with the greatest precipitation along the Appalachian spine and slightly more arid conditions on the eastern (leeward) side of the mountain range (Siler et al. 2013). However, the landscape characteristics of mountainous areas also contribute to lower catchment sensitivity. High slope (Figure 6) along the Appalachian spine in the Tennessee, Kanawha, and Monongahela basins contributes to greater water yield downstream. Catchment elasticity due to high temperate forest cover (Creed et al. 2014) and high subsurface storage contributes to greater catchment resilience and capacity to buffer climate warming. A longer growing season also has the capacity to increase evapotranspiration and stabilize streamflow (Kim et al. 2018).

The watershed sensitivity combined with future changing climate is expected to increase future $\mathrm{Q}$ by between $9 \%$ and $17 \%$ across the region, with $\mathrm{Q}$ in several catchments in the Potomac expected to increase more than $20 \%$ over the historic period. Increasing future $\mathrm{Q}$ is likely occurring in response to increasing P (Table 4) due to large scale drivers (Fernandez and Zegre 2019), more extreme and intense storms (Asadieh and Krakauer 2015), and hydrologic intensification occurring from warmer atmospheric air temperatures (Huntington 2006).

\subsubsection{Management Implications}

$\mathrm{P}$ and $\mathrm{Q}$ increases across the region has potentially important implications for infrastructure inundation, less reliable energy sources and structures, and limited ecosystem service supply (Wright et al. 2012, Neumann et al. 2015). As precipitation and extreme storms increase in frequency and duration, communities downstream of the headwater basins will experience greater occurrences of flooding (Smith et al. 2011), which will lead to storm related damage to infrastructure including bridges, buildings, cities, industry, and water treatment facilities (Suarez et al. 2005, Delpla et al. 2009). Furthermore, current infrastructure age and disrepair make damage from extreme storms more likely and costly (Reidmiller et al. 2017). Given that all watersheds in the central Appalachian regions are expected to have higher future streamflow, storm and flooding related damage is of particular concern for large population centers such as Pittsburgh and Washington D.C. Specifically, protecting the headwater reaches of the Potomac watershed is important given its high future streamflow increases $(17 \%)$ as well 
as its importance in providing clean freshwater resources to the Washington D.C. population center.

High precipitation and extreme events can lead to unreliability and unpredictability of energy sources and systems (Panteli and Mancarella 2015). Extreme precipitation events could cause damage to energy infrastructure, more frequent and longer power outages, and lapses in power generation and fuel shortages, leading to energy related price spikes (Campbell 2012, Ward 2013, Reidmiller et al. 2017). Similarly, flooding could lead to inundation of energy infrastructure such as electric lines, railways, powerplants, and refineries, leading to longer lapses in energy generation and more investment in repair and maintenance (Wilbanks et al. 2008, Burkett 2011). Therefore, greater investments will be needed to prevent or limit flooding damage through waterproofing measures, infrastructure reinforcement, increasing use of energy storage systems, and implementing measures to limit widespread power outages.

Climate change has had severe impacts on terrestrial and freshwater organisms including mismatched timing of biological events such as predation and migration, agricultural damage, and disruption to supply of clean water, which could impact ecosystem services including hunting, fishing, and drinking water resources (Rosenzweig et al. 2001, Saino et al. 2009). Earlier growing season causes by warming temperatures cue early development of insects, while the avian predators are migrating at the instinctual time (Saino et al. 2009, Clausen and Clausen 2013), therefore leading to increased insect populations, reduced avian populations, reduced pollination, and reduced agricultural output. Earlier spring could further impact agricultural crops if the date of the last-freeze overlaps the date of spring development, causing large scale crop damage and agricultural loss (Rosenzweig et al. 2001, Reidmiller et al. 2017). More frequent and extreme precipitation events could also lead to water quality issues due to erosion and sedimentation migration and greater agricultural fertilizer and pesticide runoff (Whitehead et al. 2009), which could increase water treatment cost.

To prevent or eliminate future water quality issues throughout the central Appalachian region, agriculture business should be rewarded for implementing proper erosion prevention methods and headwater catchments should be protected to maintain clean and stable freshwater resources to downstream communities (Harrison et al. 2016) and reduce water treatment costs (Abildtrup et al. 2013). Therefore, the results from this study should be applied to evaluate the effect that future precipitation, streamflow, flooding, and extreme events will have on bridges 
and water treatment facilities that may be inundated and unable to handle a large volume of water (Gersonius et al. 2013). Thoughtful implementation of watershed protection plans could minimize water quality issues given future $\mathrm{P}$ and $\mathrm{Q}$ increases that contribute to greater erosion, sedimentation, and agricultural runoff (Nearing et al. 2005). Consideration for the Potomac watershed is particularly important given it's expected high future streamflow increases (17\%), which could have important downstream flow implications to the Washington D.C. population center (Parker et al. 1907).

Watershed protection requires a multi-faceted agreement between government, public, and private entities. In the Potomac basin, a large portion of the land is privately owned, therefore, several options are available for protecting the land including downstream beneficiaries and purchase of upstream land from willing sellers. In the first option, downstream beneficiaries (in Washington D.C.) could provide financial support as incentive or in recognition of good watershed management practices upstream. A second option is to purchase land from willing sellers to protect hydrologic ecosystem services upstream. This newly acquired land could be opened for recreational use for fishing, hunting, and hiking to offset the investment. Furthermore, acquired land could be converted to forests, which would help to regulate downstream water availability and reduce water treatment costs, especially in light of high climate sensitivity in the Potomac basin as well as an expected increase in future runoff.

Upstream water protection also increases downstream water quality. One method to increase downstream water quality is to provide incentive payments to encourage proper use of agriculturally owned land. Runoff from upstream agriculture land in the Potomac basin leads to harmful algal blooms in the Chesapeake Bay (Glibert et al. 2001), which disrupts fishery and commercial industries that economically rely on the estuary. Providing incentive-based payments for proper agricultural behavior, such as reduced fertilizer and pesticide use and reduced tillage, could improve downstream drinking water quality, enhance infiltration, and reduce runoff, resulting in reduced water treatment costs (Abildtrup et al. 2013), and maintenance of ecosystem services derived from the Chesapeake bay.

\subsection{CONCLUSION}

This research quantified the sensitivity of streamflow to changing climate and land cover in 31 headwater catchments located in the central Appalachian Mountains of the eastern United 
States. The sensitivity analysis quantified streamflow change based on a change in P, PET, and catchment parameters (n). The sensitivity coefficients were used to quantify future streamflow from 2070-2099. The results showed the more arid catchments had a greater sensitivity to climate (P and PET) and land use (n) than the humid catchments. Future Q increased in all catchments under both emissions scenarios (RCP 4.5 and 8.5).

The results suggest that mountainous, high $\mathrm{P}$ catchments with lower sensitivities to changing climate have a greater ability to buffer the effect of climatic changes, allowing them to better mitigate flow variations. Precipitation had the greatest control on Q sensitivity, but other factors including growing season length and slope may have ancillary effects on runoff sensitivity but were not addressed in this study. Land use sensitivity is also greatest in the Potomac and least in the Monongahela, and we attribute this to agricultural cover in the high sensitivity basins (Ohio and Potomac), suggesting that forested basins may have a lower sensitivity to changing climate and land use than agriculturally dominated basins.

We emphasize that this research can inform management decisions for protecting water resources in an area that is expected to have increasing future $\mathrm{P}$ by suggesting the application of several management techniques in the Potomac basin. The Potomac basin is the most urgent basin for enhanced management as it provides a large portion of water resources to the Washington D.C. population center. We propose that Washington D.C. implement protective areas in the upstream Potomac basin and provide incentive-based payment programs to upstream private land owners for good ecological behavior including reduced fertilizer and pesticide use. Given the high sensitivity of the Potomac to future changing climate, and expected increase in downstream runoff, and high agricultural cover in this basin, we believe in is imperative to protect headwater basins to regulate and maintain future downstream water resources. 


\section{REFERENCES}

Abatzoglou, J. T., and T. J. Brown. 2012. A comparison of statistical downscaling methods suited for wildfire applications. International journal of climatology 32:772-780.

Abildtrup, J., S. Garcia, and A. Stenger. 2013. The effect of forest land use on the cost of drinking water supply: A spatial econometric analysis. Ecological Economics 92:126136.

Andreadis, K. M., and D. P. Lettenmaier. 2006. Trends in 20th century drought over the continental United States. Geophysical Research Letters 33.

ARC. 1970. Subregions in Appalachia. Appalachian Regional Commission.

Asadieh, B., and N. Krakauer. 2015. Global trends in extreme precipitation: climate models versus observations. Hydrology and Earth System Sciences 19:877-891.

Bates, B., Z. W. Kundzewicz, S. Wu, and J. Palutikof. 2008. climate change and Water: technical Paper vi. Intergovernmental Panel on Climate Change (IPCC).

Brzostek, E. R., D. Dragoni, H. P. Schmid, A. F. Rahman, D. Sims, C. A. Wayson, D. J. Johnson, and R. P. Phillips. 2014. Chronic water stress reduces tree growth and the carbon sink of deciduous hardwood forests. Glob Chang Biol 20:2531-2539.

Budyko, M. 1974. Climate and Life, 508 pp. Academic, San Diego, Calif:72-191.

Budyko, M. I. 1961. The heat balance of the earth's surface. Soviet Geography 2:3-13.

Burns, D. A., J. Klaus, and M. R. McHale. 2007. Recent climate trends and implications for water resources in the Catskill Mountain region, New York, USA. Journal of Hydrology 336:155-170.

Caldwell, P., G. Sun, S. McNulty, E. Cohen, and J. M. Myers. 2012. Impacts of impervious cover, water withdrawals, and climate change on river flows in the conterminous US.

Caldwell, P. V., C. F. Miniat, K. J. Elliott, W. T. Swank, S. T. Brantley, and S. H. Laseter. 2016. Declining water yield from forested mountain watersheds in response to climate change and forest mesophication. Global Change Biology 22:2997-3012.

Campbell, J. L., C. T. Driscoll, A. Pourmokhtarian, and K. Hayhoe. 2011. Streamflow responses to past and projected future changes in climate at the Hubbard Brook Experimental Forest, New Hampshire, United States. Water Resources Research 47:W02514.

Canadell, J., R. Jackson, J. Ehleringer, H. Mooney, O. Sala, and E.-D. Schulze. 1996. Maximum rooting depth of vegetation types at the global scale. Oecologia 108:583-595.

Chou, C., J. D. Neelin, C.-A. Chen, and J.-Y. Tu. 2009. Evaluating the "rich-get-richer" mechanism in tropical precipitation change under global warming. Journal of Climate 22:1982-2005.

Choudhury, B. 1999. Evaluation of an empirical equation for annual evaporation using field observations and results from a biophysical model. Journal of Hydrology 216:99-110.

Cooper, M., J. Schaperow, S. Cooley, S. Alam, L. Smith, and D. Lettenmaier. 2018. Climate Elasticity of Low Flows in the Maritime Western US Mountains. Water Resources Research 54:5602-5619.

Creed, I. F., G. Z. Sass, J. M. Buttle, and J. A. Jones. 2011. Hydrological principles for sustainable management of forest ecosystems. Hydrological Processes:n/a-n/a.

Creed, I. F., A. T. Spargo, J. A. Jones, J. M. Buttle, M. B. Adams, F. D. Beall, E. G. Booth, J. L. Campbell, D. Clow, K. Elder, M. B. Green, N. B. Grimm, C. Miniat, P. Ramlal, A. Saha, S. Sebestyen, D. Spittlehouse, S. Sterling, M. W. Williams, R. Winkler, and H. Yao. 
2014. Changing forest water yields in response to climate warming: results from longterm experimental watershed sites across North America. Glob Chang Biol 20:31913208.

Cruise, J. F., C. A. Laymon, and O. Z. Al-Hamdan. 2010. Impact of 20 Years of Land-Cover Change on the Hydrology of Streams in the Southeastern United States. JAWRA Journal of the American Water Resources Association 46:1159-1170.

Delpla, I., A.-V. Jung, E. Baures, M. Clement, and O. Thomas. 2009. Impacts of climate change on surface water quality in relation to drinking water production. Environment International 35:1225-1233.

DeWalle, D. R., B. R. Swistock, T. E. Johnson, and K. J. McGuire. 2000. Potential effects of climate change and urbanization on mean annual streamflow in the United States. Water Resources Research 36:2655-2664.

Donohue, R. J., M. L. Roderick, and T. R. McVicar. 2011. Assessing the differences in sensitivities of runoff to changes in climatic conditions across a large basin. Journal of Hydrology 406:234-244.

Dudley, N., and S. Stolton. 2003. Running pure: the importance of forest protected areas to drinking water. World Bank Publications.

Eagleson, P. S. 1978. Climate, soil, and vegetation: 1. Introduction to water balance dynamics. Water Resources Research 14:705-712.

Feng, D., E. Beighley, R. Hughes, and D. Kimbro. 2016. Spatial and Temporal Variations in Eastern US Hydrology: Responses to Global Climate Variability. JAWRA Journal of the American Water Resources Association 52:1089-1108.

Fernandes, R., and N. Zegre. 2019. Seasonal changes in water and energy balances over the Appalachian region and beyond throughout the 21st century. Hydrologic Earth System Science in review.

Fernandez, R., and T. Sayama. 2015. Comparison of future runoff projections using Budyko framework and global hydrologic model: conceptual simplicity vs process complexity. Hydrological Research Letters 9:75-83.

Ford, C. R., S. H. Laseter, W. T. Swank, and J. M. Vose. 2011. Can forest management be used to sustain water-based ecosystem services in the face of climate change? Ecological Applications 21:2049-2067.

Frank, D., B. Poulter, M. Saurer, J. Esper, C. Huntingford, G. Helle, K. Treydte, N. Zimmermann, G. Schleser, and A. Ahlström. 2015. Water-use efficiency and transpiration across European forests during the Anthropocene. Nature Climate Change 5:579.

Gaertner, B. A., N. Zegre, T. Warner, R. Fernandez, Y. He, and E. R. Merriam. 2019. Climate, forest growing season, and evapotranspiration changes in the central Appalachian Mountains, USA. Science of The Total Environment.

Gao, P., X.-M. Mu, F. Wang, and R. Li. 2011. Changes in streamflow and sediment discharge and the response to human activities in the middle reaches of the Yellow River. Hydrology and Earth System Sciences 15:1-10.

Gardner, W. 1983. Soil properties and efficient water use: an overview. Limitations to efficient water use in crop production:45-64.

Gerten, D., W. Lucht, S. Schaphoff, W. Cramer, T. Hickler, and W. Wagner. 2005. Hydrologic resilience of the terrestrial biosphere. Geophysical Research Letters 32. 
Glibert, P. M., R. Magnien, M. W. Lomas, J. Alexander, C. Tan, E. Haramoto, M. Trice, and T. M. Kana. 2001. Harmful algal blooms in the Chesapeake and coastal bays of Maryland, USA: comparison of 1997, 1998, and 1999 events. Estuaries 24:875-883.

Harrison, I. J., P. A. Green, T. A. Farrell, D. Juffe-Bignoli, L. Sáenz, and C. J. Vörösmarty. 2016. Protected areas and freshwater provisioning: a global assessment of freshwater provision, threats and management strategies to support human water security. Aquatic Conservation: Marine and Freshwater Ecosystems 26:103-120.

Hayhoe, K., C. Wake, B. Anderson, X.-Z. Liang, E. Maurer, J. Zhu, J. Bradbury, A. DeGaetano, A. Stoner, and D. Wuebbles. 2008. Regional climate change projections for the Northeast USA. Mitigation and Adaptation Strategies for Global Change 13:425-436.

Hayhoe, K., C. P. Wake, T. G. Huntington, L. Luo, M. D. Schwartz, J. Sheffield, E. Wood, B. Anderson, J. Bradbury, A. DeGaetano, T. J. Troy, and D. Wolfe. 2006. Past and future changes in climate and hydrological indicators in the US Northeast. Climate Dynamics 28:381-407.

Holling, C. S. 1973. Resilience and stability of ecological systems. Annual Review of Ecology and Systematics 4:1-23.

Homer, C., J. Dewitz, L. Yang, S. Jin, P. Danielson, G. Xian, J. Coulston, N. Herold, J. Wickham, and K. Megown. 2015. Completion of the 2011 National Land Cover Database for the conterminous United States-representing a decade of land cover change information. Photogrammetric Engineering \& Remote Sensing 81:345-354.

Huntington, T. G. 2006. Evidence for intensification of the global water cycle: Review and synthesis. Journal of Hydrology 319:83-95.

Huntington, T. G. 2010. Climate Warming-Induced Intensification of the Hydrologic Cycle. advances in agronomy 109:1-53.

Hwang, T., L. E. Band, C. F. Miniat, C. Song, P. V. Bolstad, J. M. Vose, and J. P. Love. 2014. Divergent phenological response to hydroclimate variability in forested mountain watersheds. Global Change Biology 20:2580-2595.

Hwang, T., K. L. Martin, J. M. Vose, D. Wear, B. Miles, Y. Kim, and L. E. Band. 2018. NonStationary Hydrologic Behavior in Forested Watersheds is Mediated by Climate-Induced Changes in Growing Season Length and Subsequent Vegetation Growth. Water Resources Research.

J.R. Slack, A. M. L., and Jurate Maciunas Landwehr. 2006. Hydro-Climatic Data Network (HCDN): Streamflow Data Set, 1874-1988. USGS Water-Resources Investigations Report 93-4076. U.S. Geological Survey.

Jones, J. 2011. Hydrologic responses to climate change: considering geographic context and alternative hypotheses. Hydrological Processes:n/a-n/a.

Jones, J. A., I. F. Creed, K. L. Hatcher, R. J. Warren, M. B. Adams, M. H. Benson, E. Boose, W. A. Brown, J. L. Campbell, A. Covich, D. W. Clow, C. N. Dahm, K. Elder, C. R. Ford, N. B. Grimm, D. L. Henshaw, K. L. Larson, E. S. Miles, K. M. Miles, S. D. Sebestyen, A. T. Spargo, A. B. Stone, J. M. Vose, and M. W. Williams. 2012. Ecosystem processes and human influences regulate streamflow response to climate change at long-term ecological research sites. BioScience 62:390-404.

Jones, J. A., and D. A. Post. 2004. Seasonal and successional streamflow response to forest cutting and regrowth in the northwest and eastern United States. Water Resources Research 40:doi: 10.1029/2003WR002952. 
Kim, J. H., T. Hwang, Y. Yang, C. L. Schaaf, E. Boose, and J. William Munger. 2018. Warming-induced earlier greenup leads to reduced stream discharge in a temperate mixed forest catchment. Journal of Geophysical Research: Biogeosciences.

Krakauer, N., and I. Fung. 2008. Mapping and attribution of change in streamflow in the coterminous United States. Hydrology and Earth System Sciences 12:1111-1120.

Laseter, S. H., C. R. Ford, J. M. Vose, and L. W. Swift Jr. 2012. Long-term temperature and precipitation trends at the Coweeta Hydrologic Laboratory, Otto, North Carolina, USA. Hydrology Research 43:890-901.

Li, L. J., L. Zhang, H. Wang, J. Wang, J. W. Yang, D. J. Jiang, J. Y. Li, and D. Y. Qin. 2007. Assessing the impact of climate variability and human activities on streamflow from the Wuding River basin in China. Hydrological Processes 21:3485-3491.

Lins, H. F., and J. R. Slack. 1999. Streamflow trends in the United States. Geophys. Res. Lett. 26:227-230.

Ma, H., D. Yang, S. K. Tan, B. Gao, and Q. Hu. 2010. Impact of climate variability and human activity on streamflow decrease in the Miyun Reservoir catchment. Journal of Hydrology 389:317-324.

Meinshausen, M., S. J. Smith, K. Calvin, J. S. Daniel, M. Kainuma, J.-F. Lamarque, K. Matsumoto, S. Montzka, S. Raper, and K. Riahi. 2011. The RCP greenhouse gas concentrations and their extensions from 1765 to 2300. Climatic Change 109:213.

Milly, P. 1994. Climate, interseasonal storage of soil water, and the annual water balance. Advances in Water Resources 17:19-24.

Nearing, M., V. Jetten, C. Baffaut, O. Cerdan, A. Couturier, M. Hernandez, Y. Le Bissonnais, M. Nichols, J. Nunes, and C. Renschler. 2005. Modeling response of soil erosion and runoff to changes in precipitation and cover. Catena 61:131-154.

Padrón, R. S., L. Gudmundsson, P. Greve, and S. I. Seneviratne. 2017. Large-Scale Controls of the Surface Water Balance Over Land: Insights From a Systematic Review and MetaAnalysis. Water Resources Research 53:9659-9678.

Parker, H. N., B. Willis, R. Bolster, W. Ashe, and M. Marsh. 1907. The Potomac River Basin. Water Supply and Irrigation Paper 192:297.

Patterson, L. A., B. Lutz, and M. W. Doyle. 2012. Streamflow Changes in the South Atlantic, United States During the Mid- and Late 20th Century1. JAWRA Journal of the American Water Resources Association 48:1126-1138.

Patterson, L. A., B. Lutz, and M. W. Doyle. 2013. Climate and direct human contributions to changes in mean annual streamflow in the South Atlantic, USA. Water Resources Research 49:7278-7291.

Penman, H. L. 1948. Natural evaporation from open water, bare soil and grass. Pages 120-145 in Proceedings of the Royal Society of London A: Mathematical, Physical and Engineering Sciences. The Royal Society.

Pitchford, J., C. Wu, L. Lin, J. Petty, R. Thomas, W. Veselka, D. Welsch, N. Zegre, and J. Anderson. 2011. Climate Change Effects on Hydrology and Ecology of Wetlands in the Mid-Atlantic Highlands. Wetlands:1-13.

Polsky, C., J. Allard, N. Currit, R. Crane, and B. Yarnal. 2000. The Mid-Atlantic Region and its climate: past, present, and future. Climate Research 14:161-173.

Post, D. A., and J. A. Jones. 2001. Hydrologic regimes of forested, mountainous, headwater basins in New Hampshire, North Carolina, Oregon, and Puerto Rico. Advances in Water Resources 24:1195-1210. 
Postel, S. L., and B. H. Thompson Jr. 2005. Watershed protection: Capturing the benefits of nature's water supply services. Pages 98-108 in Natural Resources Forum. Wiley Online Library.

RCore. 2014. R: A language and environment for statistical computing. R Foundation for Statistical Computing, Vienna, Austria. 2013. ISBN 3-900051-07-0.

Reidmiller, D., C. Avery, D. Easterling, K. Kunkel, K. Lewis, T. Maycock, and B. Stewart. 2017. Impacts, Risks, and Adaptation in the United States: Fourth National Climate Assessment, Volume II.

Roderick, M. L., and G. D. Farquhar. 2011. A simple framework for relating variations in runoff to variations in climatic conditions and catchment properties. Water Resources Research 47.

Roman, D., K. Novick, E. Brzostek, D. Dragoni, F. Rahman, and R. Phillips. 2015. The role of isohydric and anisohydric species in determining ecosystem-scale response to severe drought. Oecologia 179:641-654.

Sankarasubramanian, A., and R. M. Vogel. 2003. Hydroclimatology of the continental United States. Geophysical Research Letters 30.

Sankarasubramanian, A., R. M. Vogel, and J. F. Limbrunner. 2001. Climate elasticity of streamflow in the United States. Water Resources Research 37:1771-1781.

Schaake, J. C. 1990. From climate to flow. Climate change and US water resources.:177-206.

Sen, P. K. 1968. Estimates of the regression coefficient based on Kendall's tau. Journal of the American Statistical Association 63:1379-1389.

Siler, N., G. Roe, and D. Durran. 2013. On the dynamical causes of variability in the rainshadow effect: A case study of the Washington Cascades. Journal of Hydrometeorology 14:122-139.

Slack, J. R., and J. M. Landwehr. 1992. Hydro-climatic data network (HCDN); a US Geological Survey streamflow data set for the United States for the study of climate variations, 18741988. 2331-1258, US Geological Survey; Copies of this report can be purchased from USGS Books and Open-File Reports Section.

Slayer, K. L. 2014. Central Appalachians: Ecoregion Description. United States Geologic Survey.

Smith, J. A., M. L. Baeck, A. A. Ntelekos, G. Villarini, and M. Steiner. 2011. Extreme rainfall and flooding from orographic thunderstorms in the central Appalachians. Water Resour. Res. 47.

Suarez, P., W. Anderson, V. Mahal, and T. Lakshmanan. 2005. Impacts of flooding and climate change on urban transportation: A systemwide performance assessment of the Boston Metro Area. Transportation Research Part D: transport and environment 10:231-244.

U.S.CensusBureau. 2009. National population estimates: Characteristics. http://www.census.gov/popest/national/asrh/NC-EST2005-asrh.html.

Viviroli, D., H. H. Dürr, B. Messerli, M. Meybeck, and R. Weingartner. 2007. Mountains of the world, water towers for humanity: Typology, mapping, and global significance. Water Resources Research 43.

Viviroli, D., and R. Weingartner. 2004. The hydrological significance of mountains: from regional to global scale. Hydrology and Earth System Sciences Discussions 8:1017-1030.

Wang, D., and M. Hejazi. 2011. Quantifying the relative contribution of the climate and direct human impacts on mean annual streamflow in the contiguous United States. Water Resources Research 47. 
White, M., S. Running, and P. Thornton. 1999. The impact of growing-season length variability on carbon assimilation and evapotranspiration over 88 years in the eastern US deciduous forest. International Journal of Biometeorology 42:139-145.

Wu, J., C. Miao, X. Zhang, T. Yang, and Q. Duan. 2017. Detecting the quantitative hydrological response to changes in climate and human activities. Science of The Total Environment 586:328-337.

Wu, W., J. S. Clark, and J. M. Vose. 2012. Response of hydrology to climate change in the southern Appalachian Mountains using Bayesian inferences. Hydrological Processes:n/a$\mathrm{n} / \mathrm{a}$.

Wu, W., J. S. Clark, and J. M. Vose. 2014. Response of hydrology to climate change in the southern Appalachian Mountains using Bayesian inference. Hydrological Processes 28:1616-1626.

Yue, S., P. Pilon, and G. Cavadias. 2002. Power of the Mann-Kendall and Spearman's rho tests for detecting monotonic trends in hydrological series. Journal of Hydrology 259:254-271.

Zhao, G., P. Tian, X. Mu, J. Jiao, F. Wang, and P. Gao. 2014. Quantifying the impact of climate variability and human activities on streamflow in the middle reaches of the Yellow River basin, China. Journal of Hydrology 519:387-398. 


\section{TABLES/FIGURES}

Table 1: Long-term historic (1965-2015) average annual climate and water balance components in $\mathrm{mm} /$ year (potential evapotranspiration [PET], precipitation [P], streamflow [Q], evapotranspiration $[\mathrm{AET}]$, dryness index $[\mathrm{PET} / \mathrm{P}]$, and evaporative index $[\mathrm{ET} / \mathrm{P}]$ ) for catchments located in the central Appalachian Mountains region. The $\mathrm{n}$ value is a catchment specific parameter that incorporates watershed characteristics and is calculated using the Budyko framework following the Choudhury (1999) framework.

\begin{tabular}{|c|c|c|c|c|c|c|c|}
\hline Station Name & $\begin{array}{c}\text { PET } \\
(\mathrm{mm}) \\
\end{array}$ & $\begin{array}{c}\mathrm{P} \\
(\mathrm{mm}) \\
\end{array}$ & $\begin{array}{c}\mathrm{Q} \\
(\mathrm{mm}) \\
\end{array}$ & $\begin{array}{l}\text { AET } \\
(\mathrm{mm}) \\
\end{array}$ & $\mathrm{PET} / \mathrm{P}$ & $\mathrm{ET} / \mathrm{P}$ & $\mathrm{n}$ \\
\hline \multicolumn{8}{|l|}{ Monongahela } \\
\hline Casselman River at Grantsville, MD & 1222 & 1169 & 669 & 500 & 1.05 & 0.43 & 0.90 \\
\hline West Fork River at Enterprise, WV & 1300 & 1169 & 519 & 651 & 1.11 & 0.56 & 1.27 \\
\hline Youghiogheny River near Oakland, MD & 1205 & 1272 & 811 & 461 & 0.95 & 0.36 & 0.78 \\
\hline Laurel Hill Creek at Ursina, PA & 1243 & 1249 & 898 & 351 & 1.00 & 0.28 & 0.58 \\
\hline Cheat River near Parsons, WV & 1220 & 1327 & 860 & 467 & 0.92 & 0.35 & 0.71 \\
\hline Average & 1238 & 1237 & 751 & 486 & 1.0 & 0.4 & 0.8 \\
\hline \multicolumn{8}{|l|}{ Ohio } \\
\hline Little Shenango River at Greenville, PA & 1237 & 1009 & 493 & 516 & 1.23 & 0.51 & 0.95 \\
\hline Little Beaver Creek near East Liverpool, OH & 1299 & 1045 & 379 & 666 & 1.24 & 0.64 & 1.58 \\
\hline Average & 1268 & 1027 & 436 & 591 & 1.2 & 0.6 & 1.3 \\
\hline \multicolumn{8}{|l|}{ Kanawha } \\
\hline Wolf Creek near Narrows, VA & 1189 & 1244 & 715 & 530 & 0.96 & 0.43 & 0.91 \\
\hline Greenbrier River at Durbin, WV & 1252 & 1153 & 1039 & 114 & 1.09 & 0.10 & 0.87 \\
\hline Williams River at Dyer, WV & 1252 & 1153 & 1039 & 114 & 1.09 & 0.10 & 0.35 \\
\hline Cranberry River near Richwood, WV & 1363 & 1194 & 488 & 705 & 1.14 & 0.59 & 1.37 \\
\hline Big Coal River at Ashford, WV & 1357 & 1016 & 426 & 591 & 1.33 & 0.58 & 1.22 \\
\hline Bluestone River at Durbin, WV & 1287 & 1079 & 522 & 556 & 1.19 & 0.52 & 1.06 \\
\hline Greenbrier River at Alderson, WV & 1386 & 1001 & 492 & 509 & 1.38 & 0.51 & 1.04 \\
\hline Average & 1298 & 1120 & 674 & 446 & 1.2 & 0.4 & 1.0 \\
\hline \multicolumn{8}{|l|}{ Tennessee } \\
\hline North Fork Holston River near Saltsville, VA & 1424 & 1154 & 489 & 665 & 1.23 & 0.58 & 1.34 \\
\hline Clinch River above Tazewell, TN & 1421 & 1274 & 496 & 779 & 1.12 & 0.61 & 1.80 \\
\hline Little River above Townsend, TN & 1433 & 1191 & 937 & 254 & 1.20 & 0.21 & 0.48 \\
\hline Little Tennessee River near Pretniss, NC & 1455 & 1700 & 997 & 703 & 0.86 & 0.41 & 1.29 \\
\hline Average & 1433 & 1330 & 730 & 600 & 1.1 & 0.5 & 1.2 \\
\hline \multicolumn{8}{|l|}{ Potomac } \\
\hline Wills Creek near Cumberland, MD & 1327 & 985 & 494 & 491 & 1.35 & 0.50 & 0.93 \\
\hline Pototmac River near Great Cacapon, WV & 1331 & 954 & 397 & 557 & 1.40 & 0.58 & 1.15 \\
\hline Cacapon River near Great Cacapon, WV & 1360 & 996 & 325 & 670 & 1.37 & 0.67 & 1.71 \\
\hline Patterson Creek near Headsville, VS & 1287 & 1068 & 282 & 785 & 1.21 & 0.74 & 2.27 \\
\hline
\end{tabular}




\begin{tabular}{lrrrrrrr} 
Bennett Creek at Park Mills, MD & 1409 & 1084 & 392 & 692 & 1.30 & 0.64 & 1.44 \\
South Branch Potoamc River near Springfield, WV & 1337 & 971 & 340 & 631 & 1.38 & 0.65 & 1.38 \\
Conococheague Creek and Fairview, MD & 1376 & 1002 & 458 & 544 & 1.37 & 0.54 & 1.11 \\
Marsh Run at Grimes, MD & 1398 & 1011 & 234 & 778 & 1.38 & 0.77 & 2.39 \\
North Branch Potomac River at Steyer, MD & 1315 & 940 & 835 & 105 & 1.40 & 0.11 & 0.30 \\
Catoctin Creek near Middletown, MD & 1397 & 1060 & 419 & 641 & 1.32 & 0.60 & 1.31 \\
Goose Creek near Leesburg, VA & 1414 & 1080 & 370 & 710 & 1.31 & 0.66 & 1.31 \\
North Fork Shenandoah River at Cootes Store, VA & 1355 & 994 & 347 & 647 & 1.36 & 0.65 & 1.36 \\
Cedar Creek near Winchester, VA & 1386 & 1038 & 49 & 989 & 1.33 & 0.95 & 7.31 \\
Average & 1361 & 1014 & 380 & 634 & 1.3 & 0.6 & 1.8 \\
\hline Overall Average & 1330 & 1116 & 555 & 560 & 1.2 & 0.5 & 1.4 \\
\hline
\end{tabular}

Table 2: Mann-Kendall trend analysis for PET, P, and ET for the 31study watersheds from 19652015 shown as total change over the study period based on the Sen slope value. All values are represented as in percentage change from the annual historic streamflow amount (Table 1). * $\underline{\text { represents significance at alpha }=0.05 \text { and } * * \text { represent significance at alpha }<0.01}$.

\begin{tabular}{|c|c|c|c|}
\hline Station Name & PET & $\mathrm{P}(\%)$ & $\begin{array}{r}\text { ET } \\
(\%) \\
\end{array}$ \\
\hline \multicolumn{4}{|l|}{ Monongahela } \\
\hline Casselman River at Grantsville, MD & $2 * *$ & 0 & -16 \\
\hline West Fork River at Enterprise, WV & $2 * *$ & -1 & -12 \\
\hline Youghiogheny River near Oakland, MD & $2 * *$ & -1 & -14 \\
\hline Laurel Hill Creek at Ursina, PA & $2 * *$ & -1 & -7 \\
\hline Cheat River near Parsons, WV & $2 * *$ & 0 & -13 \\
\hline Average & 2 & -1 & -12 \\
\hline \multicolumn{4}{|l|}{ Ohio } \\
\hline Little Shenango River at Greenville, PA & $2 * *$ & 0 & 0 \\
\hline Little Beaver Creek near East Liverpool, OH & $2 * *$ & 0 & -2 \\
\hline Average & 2 & 0 & -1 \\
\hline \multicolumn{4}{|l|}{ Kanawha } \\
\hline Wolf Creek near Narrows, VA & $2 * *$ & -1 & 0 \\
\hline Greenbrier River at Durbin, WV & $2 * *$ & -1 & -3 \\
\hline Williams River at Dyer, WV & $2 * *$ & -1 & -4 \\
\hline Cranberry River near Richwood, WV & $2 * *$ & -1 & -4 \\
\hline Big Coal River at Ashford, WV & $2 * *$ & -1 & -1 \\
\hline Bluestone River at Durbin, WV & $2 * *$ & -1 & 9 \\
\hline Greenbrier River at Alderson, WV & $2 * *$ & -1 & -11 \\
\hline Average & 2 & 1 & -2 \\
\hline
\end{tabular}




\begin{tabular}{lrrr} 
North Fork Holston River near Saltsville, VA & $2 * *$ & -1 & 3 \\
Clinch River above Tazewell, TN & $2 * *$ & -2 & -2 \\
Little River above Townsend, TN & $2 * *$ & -4 & 6 \\
Little Tennessee River near Pretniss, NC & $2 * *$ & -1 & 2 \\
Average & 2 & -2 & 2 \\
\hline Potomac & & & \\
Wills Creek near Cumberland, MD & $2 * *$ & -1 & -6 \\
Pototmac River near Great Cacapon, WV & $2 * *$ & -1 & 8 \\
Cacapon River near Great Cacapon, WV & $2 * *$ & 0 & -11 \\
Patterson Creek near Headsville, VS & $3 * *$ & -1 & 2 \\
Bennett Creek at Park Mills, MD & $2 * *$ & -1 & -12 \\
South Branch Potoamc River near Springfield, WV & $2 * *$ & -1 & -3 \\
Conococheague Creek and Fairview, MD & $3 * *$ & -1 & -14 \\
Marsh Run at Grimes, MD & $2 * *$ & -1 & -19 \\
North Branch Potomac River at Steyer, MD & $2 * *$ & 0 & 4 \\
Catoctin Creek near Middletown, MD & $2 * *$ & 1 & -10 \\
Goose Creek near Leesburg, VA & $2 * *$ & -1 & -8 \\
North Fork Shenandoah River at Cootes Store, VS & $2 * *$ & -1 & -14 \\
Cedar Creek near Winchester, VA & $2 * *$ & -1 & -10 \\
Average & 2 & -1 & -7 \\
\hline Overall Average & 2 & -1 & -5 \\
\hline
\end{tabular}

Table 3: Future PET, P, and dryness index (PET/P) for each catchment from 2015-2099 based on future ensemble climate data from the Multivariate Adaptive Constructed Analogs version 2 (MACAv2-METDATA) dataset (Abatzoglou and Brown 2012). The Station name corresponds to the USGS HCDN watershed output station name. $\mathrm{RCP}_{4.5}$ refers to the 4.5 emission scenario for future climate projections, while $\mathrm{RCP}_{8.5}$ refers to the 8.5 emission scenario .(Meinshausen et al. 2011)

\begin{tabular}{|c|c|c|c|c|c|c|}
\hline Station Name & $\begin{array}{l}\mathrm{PET}_{4.5} \\
(\mathrm{~mm})\end{array}$ & $\begin{array}{l}\mathrm{PET}_{8.5} \\
(\mathrm{~mm}) \\
\end{array}$ & $\begin{array}{l}\mathrm{P}_{4.5} \\
(\mathrm{~mm}) \\
\end{array}$ & $\begin{array}{l}P_{8.5} \\
(\mathrm{~mm}) \\
\end{array}$ & $\mathrm{PET} / \mathrm{P}_{4.5}$ & $\mathrm{PET} / \mathrm{P}_{8.5}$ \\
\hline \multicolumn{7}{|l|}{ Monongahela } \\
\hline Casselman River at Grantsville, MD & 1413 & 1567 & 1265 & 1289 & 0.90 & 0.82 \\
\hline West Fork River at Enterprise, WV & 1494 & 1642 & 1259 & 1282 & 0.84 & 0.78 \\
\hline Youghiogheny River near Oakland, MD & 1382 & 1528 & 1373 & 1396 & 0.99 & 0.91 \\
\hline Laurel Hill Creek at Ursina, PA & 1428 & 1579 & 1346 & 1370 & 0.94 & 0.87 \\
\hline Cheat River near Parsons, WV & 1399 & 1549 & 1429 & 1449 & 1.02 & 0.94 \\
\hline Average & 1423 & 1573 & 1334 & 1357 & 0.94 & 0.86 \\
\hline \multicolumn{7}{|l|}{ Ohio } \\
\hline Little Shenango River at Greenville, PA & 1439 & 1591 & 1085 & 1121 & 0.75 & 0.70 \\
\hline Little Beaver Creek near East Liverpool, OH & 1504 & 1656 & 1121 & 1152 & 0.75 & 0.70 \\
\hline
\end{tabular}




\begin{tabular}{|c|c|c|c|c|c|c|}
\hline Average & 1472 & 1623 & 1103 & 1136 & 0.75 & 0.70 \\
\hline \multicolumn{7}{|l|}{ Kanawha } \\
\hline Wolf Creek near Narrows, VA & 1369 & 1516 & 1346 & 1366 & 0.98 & 0.90 \\
\hline Greenbrier River at Durbin, WV & 1401 & 1543 & 1584 & 1601 & 1.13 & 1.04 \\
\hline Williams River at Dyer, WV & 1435 & 1568 & 1240 & 1254 & 0.86 & 0.80 \\
\hline Cranberry River near Richwood, WV & 1562 & 1708 & 1272 & 1282 & 0.81 & 0.75 \\
\hline Big Coal River at Ashford, WV & 1566 & 1713 & 1091 & 1102 & 0.70 & 0.64 \\
\hline Bluestone River at Durbin, WV & 1481 & 1619 & 1158 & 1172 & 0.78 & 0.72 \\
\hline Greenbrier River at Alderson, WV & 1595 & 1736 & 1075 & 1095 & 0.67 & 0.63 \\
\hline Average & 1487 & 1629 & 1252 & 1267 & 0.85 & 0.78 \\
\hline \multicolumn{7}{|l|}{ Tennessee } \\
\hline North Fork Holston River near Saltsville, VA & 1624 & 1762 & 1230 & 1237 & 0.76 & 0.70 \\
\hline Clinch River above Tazewell, TN & 1608 & 1735 & 1348 & 1350 & 0.84 & 0.78 \\
\hline Little River above Townsend, TN & 1624 & 1750 & 1262 & 1262 & 0.78 & 0.72 \\
\hline Little Tennessee River near Pretniss, NC & 1623 & 1756 & 1813 & 1805 & 1.12 & 1.03 \\
\hline Average & 1620 & 1751 & 1413 & 1414 & 0.87 & 0.81 \\
\hline \multicolumn{7}{|l|}{ Potomac } \\
\hline Wills Creek near Cumberland, MD & 1538 & 1688 & 1070 & 1094 & 0.70 & 0.65 \\
\hline Pototmac River near Great Cacapon, WV & 1544 & 1693 & 1038 & 1059 & 0.67 & 0.63 \\
\hline Cacapon River near Great Cacapon, WV & 1573 & 1721 & 1086 & 1111 & 0.69 & 0.65 \\
\hline Patterson Creek near Headsville, VS & 1489 & 1640 & 1156 & 1180 & 0.78 & 0.72 \\
\hline Bennett Creek at Park Mills, MD & 1623 & 1773 & 1182 & 1212 & 0.73 & 0.68 \\
\hline South Branch Potoamc River near Springfield, WV & 1552 & 1704 & 1057 & 1077 & 0.68 & 0.63 \\
\hline Conococheague Creek and Fairview, MD & 1590 & 1740 & 1093 & 1118 & 0.69 & 0.64 \\
\hline Marsh Run at Grimes, MD & 1615 & 1767 & 1105 & 1134 & 0.68 & 0.64 \\
\hline North Branch Potomac River at Steyer, MD & 1529 & 1680 & 1018 & 1039 & 0.67 & 0.62 \\
\hline Catoctin Creek near Middletown, MD & 1612 & 1764 & 1159 & 1188 & 0.72 & 0.67 \\
\hline Goose Creek near Leesburg, VA & 1628 & 1781 & 1177 & 1205 & 0.72 & 0.68 \\
\hline North Fork Shenandoah River at Cootes Store, VS & 1573 & 1727 & 1081 & 1101 & 0.69 & 0.64 \\
\hline Cedar Creek near Winchester, VA & 1599 & 1749 & 1132 & 1153 & 0.71 & 0.66 \\
\hline Average & 1574 & 1725 & 1104 & 1128 & 0.70 & 0.65 \\
\hline Overall Average & 1529 & 1676 & 1215 & 1234 & 0.80 & 0.74 \\
\hline
\end{tabular}


Table 4: Relative change (\%) in PET and P between historical (1965-2015) and future (20152099) climate. $\mathrm{RCP}_{4.5}$ refers to the 4.5 emission scenario for future climate projections, while $\mathrm{RCP}_{8.5}$ refers to the 8.5 emission scenario.

\begin{tabular}{|c|c|c|c|c|}
\hline Station Name & $\begin{array}{c}\Delta \mathrm{PET}_{\mathrm{RCP} 4.5} \\
\quad(\%)\end{array}$ & $\begin{array}{c}\Delta \mathrm{PET}_{\mathrm{RCP} 8.5} \\
(\%)\end{array}$ & $\begin{array}{c}\Delta \mathrm{P}_{\mathrm{RCP} 4.5} \\
(\%)\end{array}$ & $\begin{array}{c}\Delta \mathrm{P}_{\mathrm{RCP} 8.5} \\
(\%)\end{array}$ \\
\hline \multicolumn{5}{|l|}{ Monongahela } \\
\hline Casselman River at Grantsville, MD & 16 & 28 & 8 & 10 \\
\hline West Fork River at Enterprise, WV & 15 & 26 & 8 & 10 \\
\hline Youghiogheny River near Oakland, MD & 15 & 27 & 8 & 10 \\
\hline Laurel Hill Creek at Ursina, PA & 15 & 27 & 8 & 10 \\
\hline Cheat River near Parsons, WV & 15 & 27 & 8 & 9 \\
\hline Average & 15 & 27 & 8 & 10 \\
\hline \multicolumn{5}{|l|}{ Ohio } \\
\hline Little Shenango River at Greenville, PA & 16 & 29 & 7 & 11 \\
\hline Little Beaver Creek near East Liverpool, OH & 16 & 28 & 7 & 10 \\
\hline Average & 16 & 28 & 7 & 11 \\
\hline \multicolumn{5}{|l|}{ Kanawha } \\
\hline Wolf Creek near Narrows, VA & 15 & 28 & 8 & 10 \\
\hline Greenbrier River at Durbin, WV & 12 & 23 & 7 & 8 \\
\hline Williams River at Dyer, WV & 15 & 25 & 8 & 9 \\
\hline Cranberry River near Richwood, WV & 15 & 25 & 7 & 8 \\
\hline Big Coal River at Ashford, WV & 15 & 26 & 7 & 9 \\
\hline Bluestone River at Durbin, WV & 15 & 26 & 8 & 9 \\
\hline Greenbrier River at Alderson, WV & 15 & 25 & 8 & 10 \\
\hline Average & 15 & 25 & 7 & 9 \\
\hline \multicolumn{5}{|l|}{ Tennessee } \\
\hline North Fork Holston River near Saltsville, VA & 14 & 24 & 7 & 7 \\
\hline Clinch River above Tazewell, TN & 13 & 22 & 6 & 6 \\
\hline Little River above Townsend, TN & 13 & 22 & 6 & 6 \\
\hline Little Tennessee River near Pretniss, NC & 12 & 21 & 7 & 7 \\
\hline Average & 13 & 22 & 7 & 7 \\
\hline \multicolumn{5}{|l|}{ Potomac } \\
\hline Wills Creek near Cumberland, MD & 16 & 27 & 9 & 11 \\
\hline Pototmac River near Great Cacapon, WV & 16 & 27 & 9 & 11 \\
\hline Cacapon River near Great Cacapon, WV & 16 & 27 & 9 & 12 \\
\hline Patterson Creek near Headsville, VS & 16 & 27 & 8 & 11 \\
\hline Bennett Creek at Park Mills, MD & 15 & 26 & 9 & 12 \\
\hline South Branch Potoamc River near Springfield, WV & 16 & 27 & 9 & 11 \\
\hline Conococheague Creek and Fairview, MD & 16 & 26 & 9 & 12 \\
\hline Marsh Run at Grimes, MD & 16 & 26 & 9 & 12 \\
\hline
\end{tabular}




\begin{tabular}{lllll} 
North Branch Potomac River at Steyer, MD & 16 & 28 & 9 & 11 \\
Catoctin Creek near Middletown, MD & 15 & 26 & 9 & 12 \\
Goose Creek near Leesburg, VA & 15 & 26 & 9 & 12 \\
North Fork Shenandoah River at Cootes Store, VS & 16 & 27 & 9 & 11 \\
Cedar Creek near Winchester, VA & 15 & 26 & 9 & 11 \\
Average & 16 & 27 & 9 & 11 \\
\hline Overall Average & 15 & 26 & 8 & 10 \\
\hline
\end{tabular}

Table 5: Streamflow (Q) sensitivity to climate variability, where $\partial \mathrm{Q} / \partial \mathrm{P}$ indicates the $\mathrm{Q}$ sensitivity to an increase in precipitation, $\partial \mathrm{Q} / \partial \mathrm{PET}$ indicates $\mathrm{Q}$ sensitivity to an increase in Potential Evapotranspiration, and $\partial \mathrm{Q} / \partial \mathrm{n}$ indicates $\mathrm{Q}$ sensitivity to a change in watershed characteristics (e.g. land use). An increase in P will increase streamflow, an increase in PET and $\mathrm{n}$ will decrease streamflow.

\begin{tabular}{|c|c|c|c|}
\hline Station Name & $\begin{array}{c}\partial \mathrm{Q} / \partial \mathrm{P} \\
(\%) \\
\end{array}$ & $\begin{array}{c}\partial \mathrm{Q} / \partial \mathrm{PET} \\
(\%) \\
\end{array}$ & $\begin{array}{c}\partial \mathrm{Q} / \partial \mathrm{n} \\
(\%) \\
\end{array}$ \\
\hline \multicolumn{4}{|l|}{ Monongahela } \\
\hline Casselman River at Grantsville, MD & 13.9 & 3.9 & 5.6 \\
\hline West Fork River at Enterprise, WV & 16.5 & 6.5 & 6.7 \\
\hline Youghiogheny River near Oakland, MD & 13.0 & 3.0 & 4.9 \\
\hline Laurel Hill Creek at Ursina, PA & 12.0 & 2.0 & 4.4 \\
\hline Cheat River near Parsons, WV & 12.7 & 2.7 & 4.8 \\
\hline Average & 13.6 & 3.6 & 5.3 \\
\hline \multicolumn{4}{|l|}{ Ohio } \\
\hline Little Shenango River at Greenville, PA & 14.6 & 4.6 & 6.8 \\
\hline Little Beaver Creek near East Liverpool, OH & 19.1 & 9.1 & 7.9 \\
\hline Average & 16.9 & 6.9 & 7.4 \\
\hline \multicolumn{4}{|l|}{ Kanawha } \\
\hline Wolf Creek near Narrows, VA & 14.0 & 4.0 & 5.5 \\
\hline Greenbrier River at Durbin, WV & 13.3 & 3.3 & 4.5 \\
\hline Williams River at Dyer, WV & 10.8 & 0.8 & 2.9 \\
\hline Cranberry River near Richwood, WV & 17.5 & 7.5 & 7.4 \\
\hline Big Coal River at Ashford, WV & 16.9 & 6.9 & 8.3 \\
\hline Bluestone River at Durbin, WV & 15.3 & 5.3 & 6.9 \\
\hline Greenbrier River at Alderson, WV & 15.6 & 5.6 & 8.0 \\
\hline Average & 14.8 & 4.8 & 6.2 \\
\hline \multicolumn{4}{|l|}{ Tennessee } \\
\hline North Fork Holston River near Saltsville, VA & 17.5 & 7.5 & 7.8 \\
\hline Clinch River above Tazewell, TN & 19.7 & 9.7 & 6.7 \\
\hline Little River above Townsend, TN & 11.5 & 1.5 & 4.3 \\
\hline
\end{tabular}




\begin{tabular}{lrrr} 
Little Tennessee River near Pretniss, NC & 15.5 & 5.5 & 4.5 \\
Average & 16.0 & 6.0 & 5.8 \\
\hline Potomac & & & \\
Wills Creek near Cumberland, MD & 14.7 & 4.7 & 7.4 \\
Pototmac River near Great Cacapon, WV & 16.5 & 6.5 & 8.4 \\
Cacapon River near Great Cacapon, WV & 20.6 & 10.6 & 9.4 \\
Patterson Creek near Headsville, VS & 23.8 & 13.8 & 8.2 \\
Bennett Creek at Park Mills, MD & 18.3 & 8.3 & 8.3 \\
South Branch Potoamc River near Springfield, WV & 18.3 & 8.3 & 9.1 \\
Conococheague Creek and Fairview, MD & 16.1 & 6.1 & 8.1 \\
Marsh Run at Grimes, MD & 26.3 & 16.3 & 10.9 \\
North Branch Potomac River at Steyer, MD & 10.6 & 0.6 & 2.9 \\
Catoctin Creek near Middletown, MD & 17.4 & 7.4 & 8.2 \\
Goose Creek near Leesburg, VA & 17.4 & 7.4 & 8.2 \\
North Fork Shenandoah River at Cootes Store, VS & 18.2 & 8.2 & 9.3 \\
Cedar Creek near Winchester, VA & 70.1 & 60.1 & 16.8 \\
Average & 22.2 & 12.2 & 8.9 \\
\hline Overall Average & 18.0 & 8.0 & 7.2 \\
\hline
\end{tabular}

Table 6: Future streamflow change relative to historical Q in mm from 2070-2099 calculated using the $\mathrm{Q}$ sensitivity to $\mathrm{P}$ and PET (Table 3). Future streamflow was calculated under a low emissions scenario (RCP 4.5) and a high emissions scenario (RCP 8.5) for each catchment and basin (in bold).

\begin{tabular}{lrr}
\hline Station Name & $\begin{array}{r}\Delta \mathrm{Q}_{4.5} \\
(\%)\end{array}$ & \multicolumn{1}{c}{$\begin{array}{c}\Delta \mathrm{Q}_{8.5} \\
(\%)\end{array}$} \\
\hline \hline Monongahela & & \\
Casselman River at Grantsville, MD & 10.6 & 10.4 \\
West Fork River at Enterprise, WV & 13.4 & 13.0 \\
Youghiogheny River near Oakland, MD & 8.8 & 8.7 \\
Laurel Hill Creek at Ursina, PA & 8.0 & 8.0 \\
Cheat River near Parsons, WV & 8.3 & 8.2 \\
Average & 9.4 & 9.3 \\
\hline Ohio & & \\
Little Shenango River at Greenville, PA & 14.1 & 14.0 \\
Little Beaver Creek near East Liverpool, OH & 17.9 & 17.2 \\
Average & 15.7 & 15.4 \\
\hline Kanawha & & \\
Wolf Creek near Narrows, VA & 10.0 & 9.7
\end{tabular}




\begin{tabular}{|c|c|c|}
\hline Greenbrier River at Durbin, WV & 6.9 & 6.9 \\
\hline Williams River at Dyer, WV & 6.9 & 7.0 \\
\hline Cranberry River near Richwood, WV & 14.0 & 13.2 \\
\hline Big Coal River at Ashford, WV & 16.2 & 15.5 \\
\hline Bluestone River at Durbin, WV & 13.4 & 13.0 \\
\hline Greenbrier River at Alderson, WV & 14.2 & 14.0 \\
\hline Average & 10.4 & 10.2 \\
\hline \multicolumn{3}{|l|}{ Tennessee } \\
\hline North Fork Holston River near Saltsville, VA & 14.1 & 13.4 \\
\hline Clinch River above Tazewell, TN & 13.7 & 12.8 \\
\hline Little River above Townsend, TN & 7.6 & 7.5 \\
\hline Little Tennessee River near Pretniss, NC & 7.1 & 6.8 \\
\hline Average & 9.5 & 9.2 \\
\hline \multicolumn{3}{|l|}{ Potomac } \\
\hline Wills Creek near Cumberland, MD & 14.4 & 14.2 \\
\hline Pototmac River near Great Cacapon, WV & 17.8 & 17.3 \\
\hline Cacapon River near Great Cacapon, WV & 21.5 & 20.6 \\
\hline Patterson Creek near Headsville, VS & 23.9 & 21.9 \\
\hline Bennett Creek at Park Mills, MD & 18.0 & 17.5 \\
\hline South Branch Potoamc River near Springfield, WV & 20.6 & 19.6 \\
\hline Conococheague Creek and Fairview, MD & 15.6 & 15.3 \\
\hline Marsh Run at Grimes, MD & 29.4 & 27.3 \\
\hline North Branch Potomac River at Steyer, MD & 8.7 & 8.8 \\
\hline Catoctin Creek near Middletown, MD & 17.0 & 16.6 \\
\hline Goose Creek near Leesburg, VA & 19.0 & 18.3 \\
\hline North Fork Shenandoah River at Cootes Store, VS & 20.1 & 19.2 \\
\hline Cedar Creek near Winchester, VA & 11.9 & 7.2 \\
\hline Average & 17.2 & 16.5 \\
\hline Overall Average & 14.3 & 13.7 \\
\hline
\end{tabular}




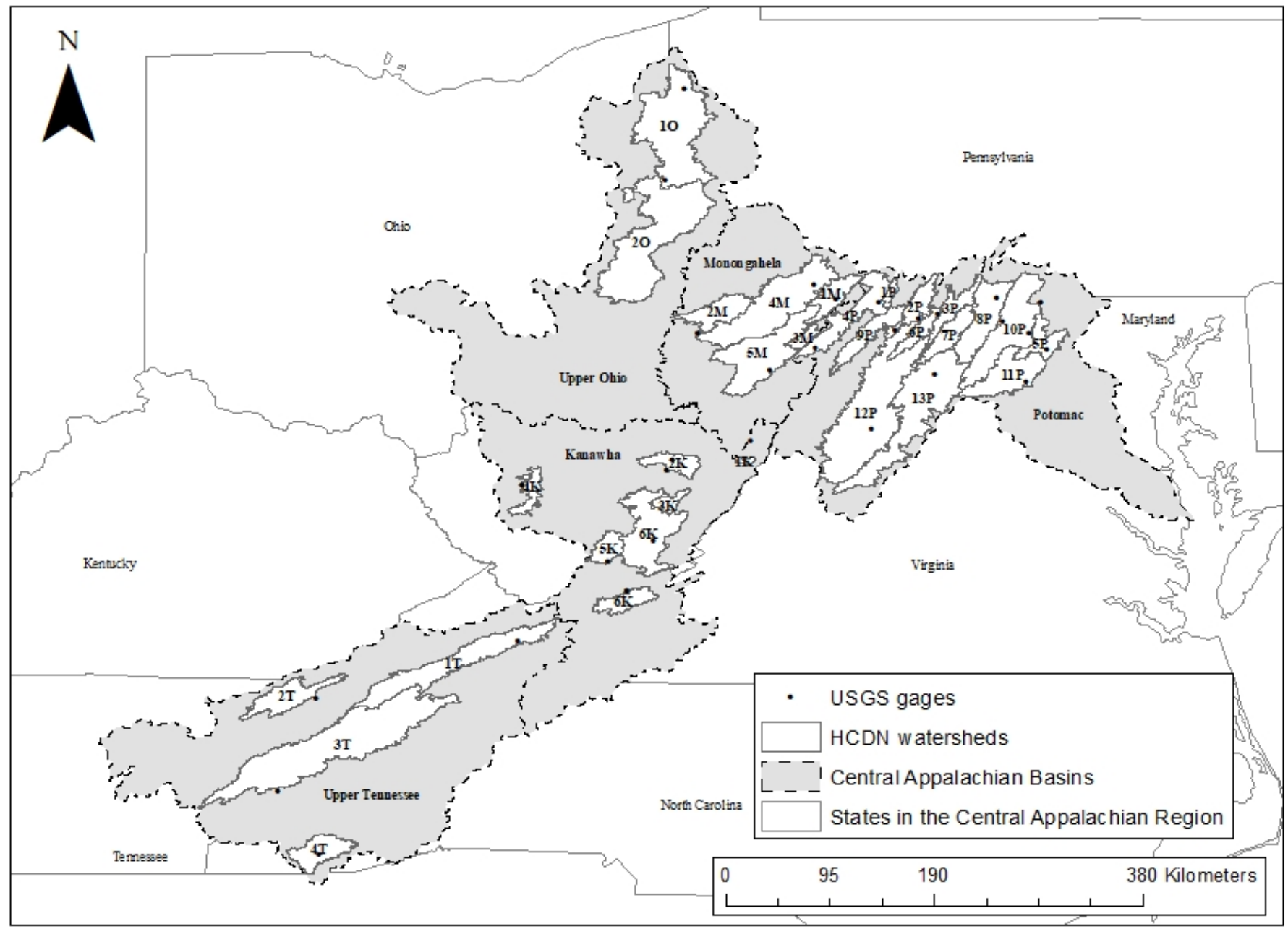

Figure 1: Location of the study area in the central Appalachian Mountains region of the eastern USA. The dashed lines depict basin boundaries of the five basins examined in this study: Potomac (P), Monongahela (M), Ohio (O), Kanawha (K), and Tennessee (T). The solid lines outline the 31 HCDN watersheds, and the identifiers label the basin followed by an HCDN (Slack and Landwehr 1992) watershed number from 1 to j. 


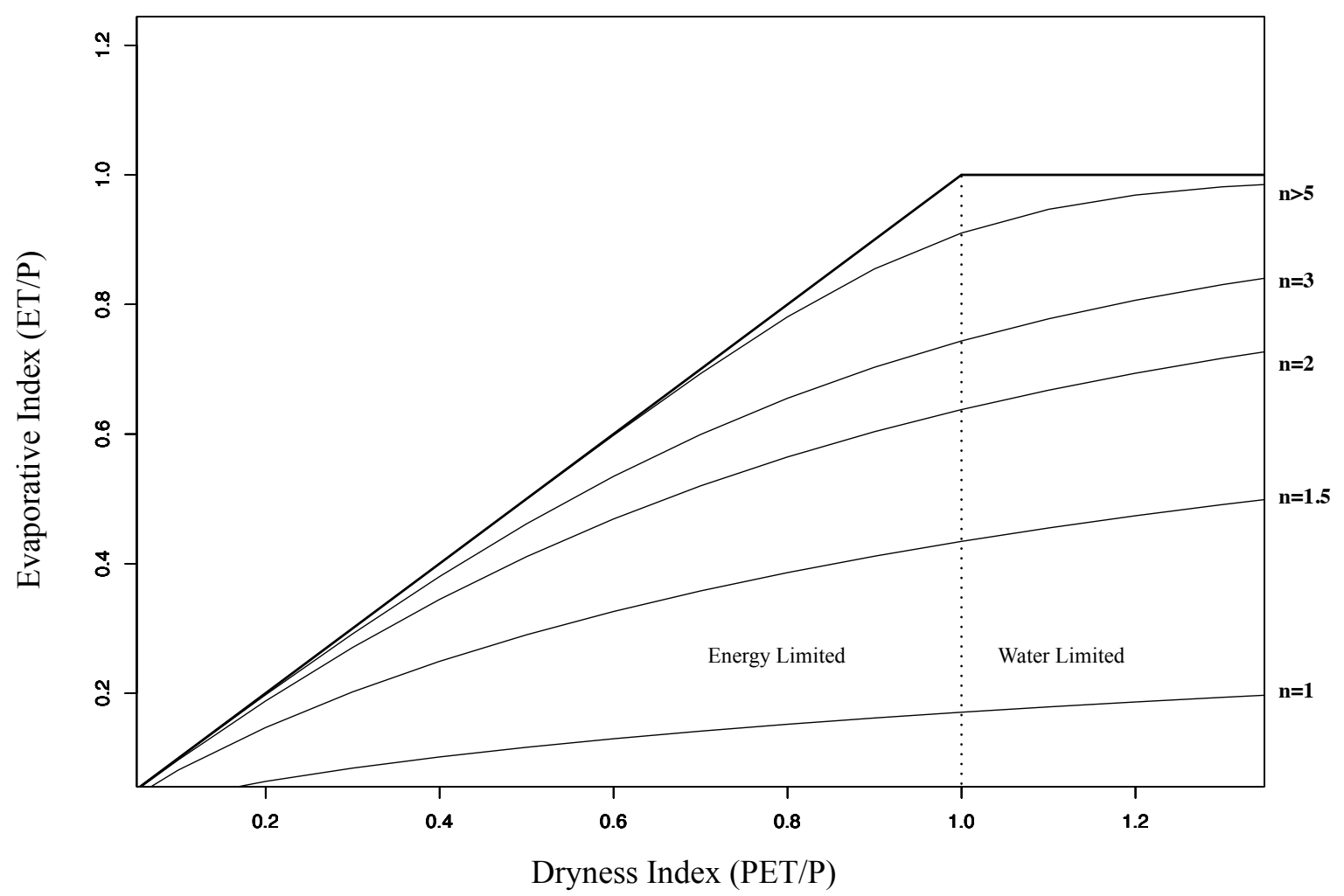

Figure 2: Conceptual figure illustrating the Budyko framework for the central Appalachian region. The dryness index represents energy limited $(\mathrm{PET} / \mathrm{P}<1)$ and water limited $(\mathrm{PET} / \mathrm{P}>1)$ basins. An energy limited basin receives greater $\mathrm{P}$ than PET, while a water limited basins receive a higher ratio of $\mathrm{P}$ to $\mathrm{PET}$. The evaporative index $(\mathrm{E} / \mathrm{P})$ provides watershed specific climatic factors, with a high $\mathrm{E} / \mathrm{P}$ representing no runoff and low representing high runoff. $\mathrm{n}$ values curves implement catchment specific factors into the Budyko framework. High $\mathrm{n}$ factors translate to low runoff and low $\mathrm{n}$ factors generally have high runoff. 

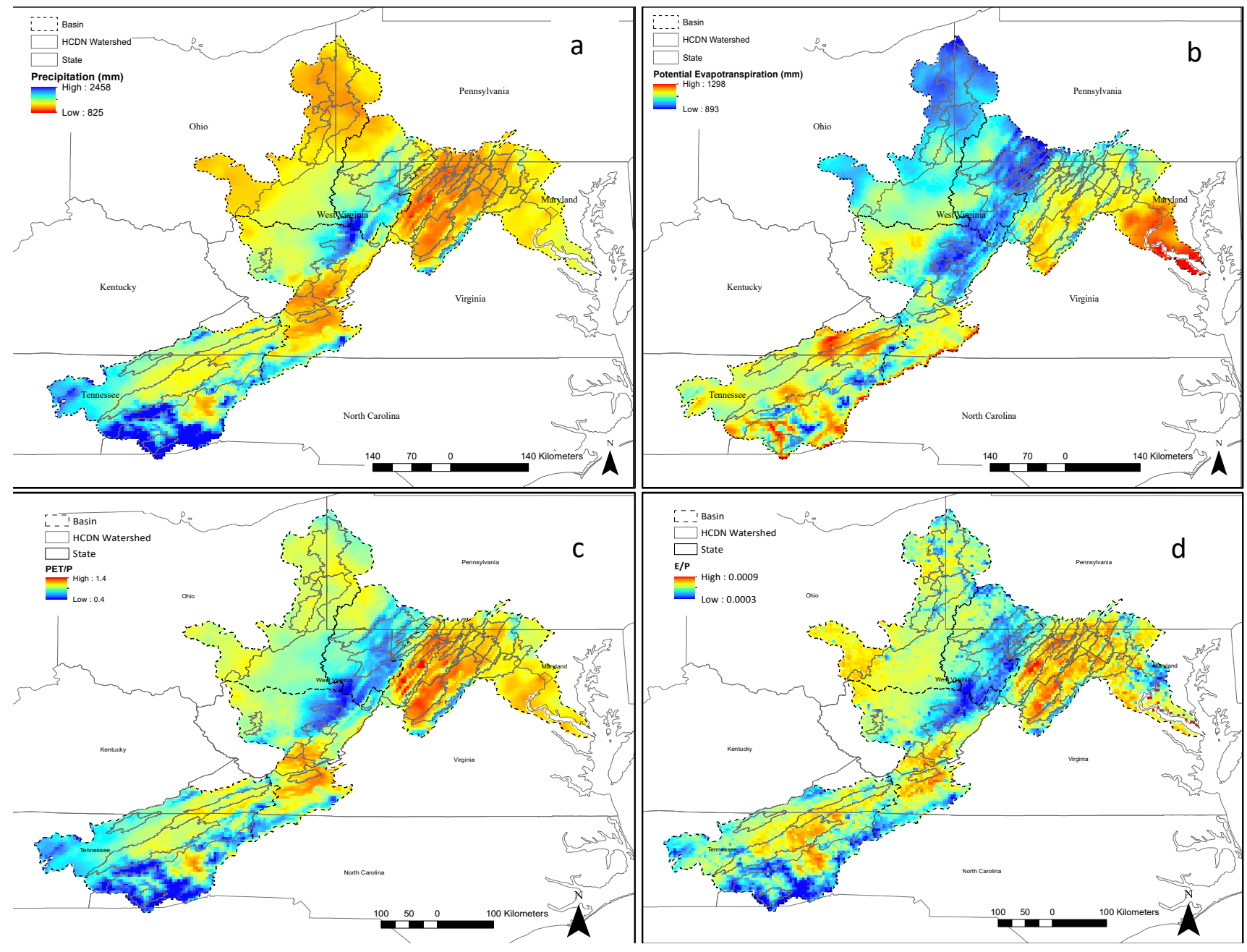

Figure 3: Climate and Budyko variables for the central Appalachian Mountain region from 19652015 including (a.) annual precipitation ( $\mathrm{mm})$, (b.) average annual potential evapotranspiration, (c.) annual evaporative index, (d.) annual dryness index (P/PET). 


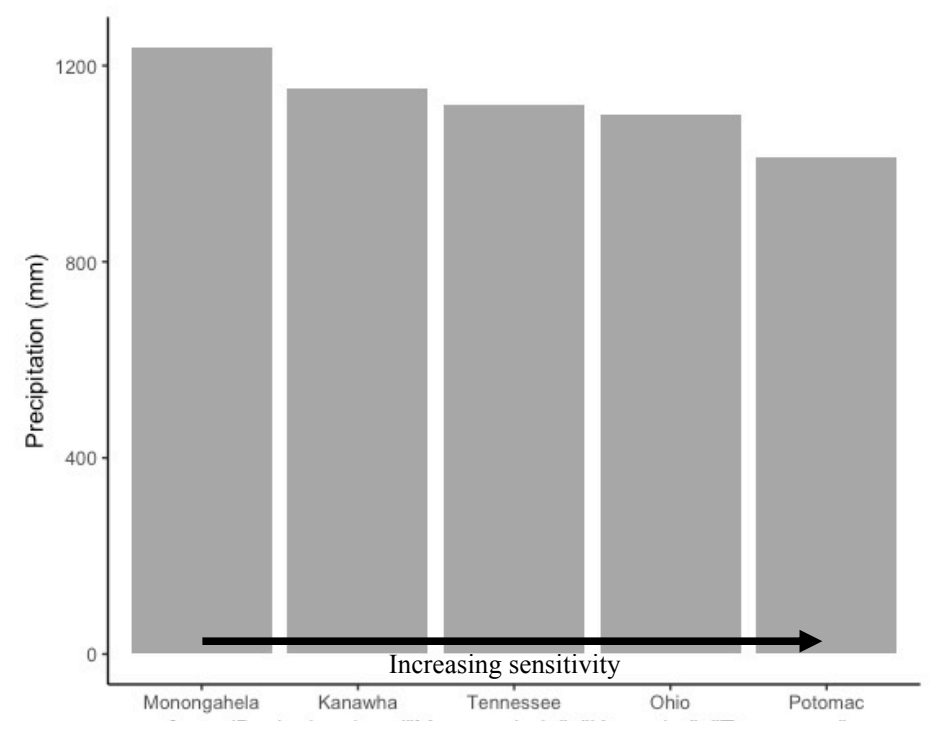

Figure 4: Average annual precipitation for the five basins located in the central Appalachian region showing a general increase in streamflow sensitivity to decreases in Precipitation. 


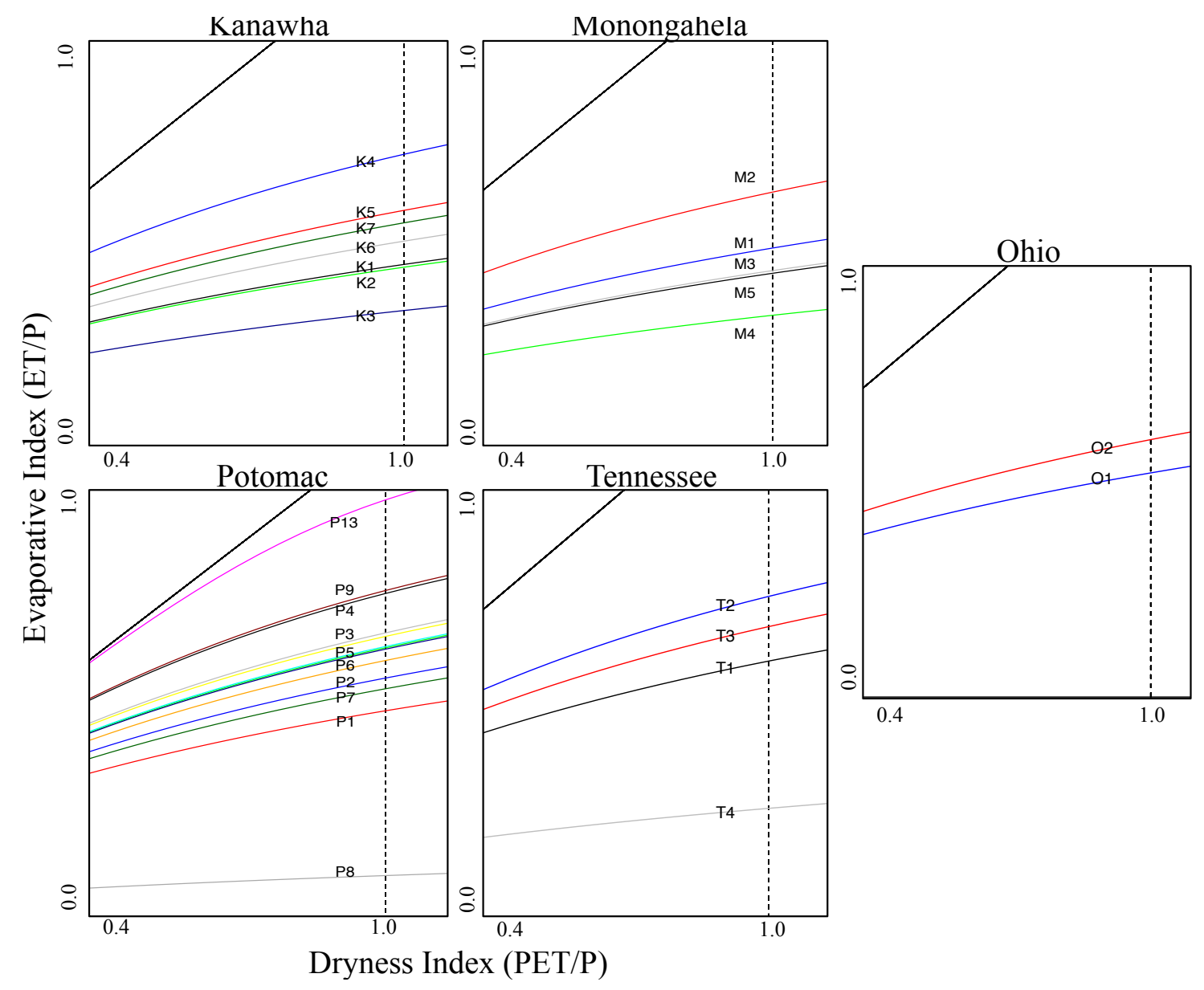

Figure 5: Relationship between the evapotranspiration ratio and dryness index of each basin for the period 1965-2015. Each identifier number refers to the watersheds depicted in Figure 1. All catchments were considered to be energy limited and average $\mathrm{n}$ values were 1.37 and ranged from 0.3 to 7.31 (both in the Potomac basin). 


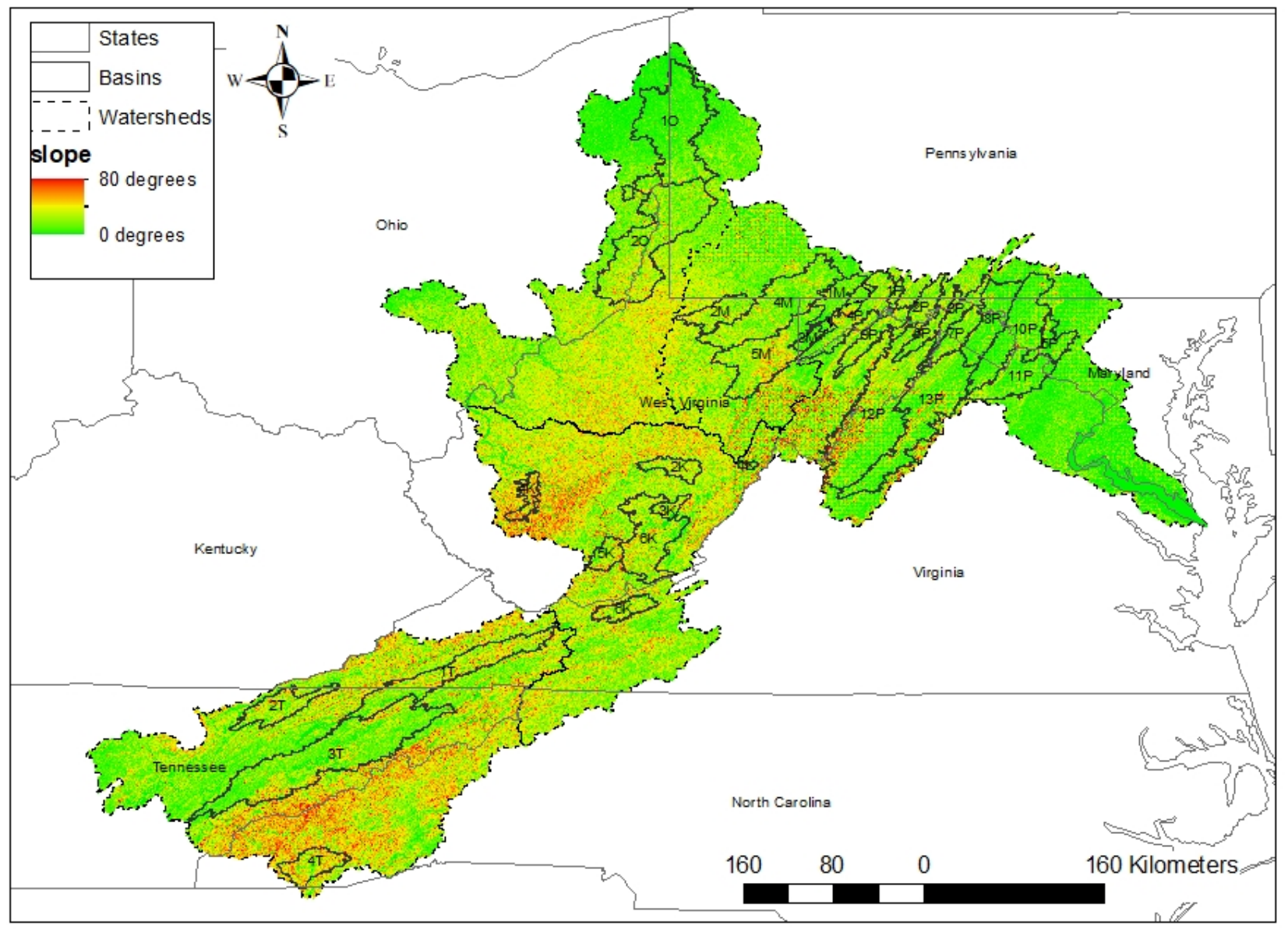

Figure 6: Slope of the central Appalachian Mountains, with red representing steep slopes (close to vertical) and green representing low slope. 
Supplementary Information:

\begin{tabular}{|c|c|c|c|c|}
\hline \multirow[b]{2}{*}{ Identifier } & \multirow[b]{2}{*}{ Basin } & \multicolumn{2}{|l|}{ Station } & \multirow[b]{2}{*}{ Area $\left(\mathrm{km}^{2}\right)$} \\
\hline & & Number & Station Name & \\
\hline $1 \mathrm{1M}$ & Monongahela & 3078000 & Casselman River at Grantsville, MD & 163 \\
\hline $2 \mathrm{M}$ & Monongahela & 3061000 & West Fork River at Enterprise, WV & 1966 \\
\hline $3 \mathrm{M}$ & Monongahela & 3075500 & Youghiogheny River near Oakland, MD & 347 \\
\hline $4 \mathrm{M}$ & Monongahela & 3080000 & Laurel Hill Creek at Ursina, PA & 313 \\
\hline $5 \mathrm{M}$ & Monongahela & 3069500 & Cheat River near Parsons, WV & 1860 \\
\hline 10 & Ohio & 3102500 & Little Shenango River at Greenville, PA & 269 \\
\hline $2 \mathrm{O}$ & Ohio & 3109500 & Little Beaver Creek near East Liverpool, OH & 1285 \\
\hline $7 \mathrm{~K}$ & Kanawha & 3175500 & Wolf Creek near Narrows, VA & 578 \\
\hline $1 \mathrm{~K}$ & Kanawha & 3180500 & Greenbrier River at Durbin, WV & 344 \\
\hline $2 \mathrm{~K}$ & Kanawha & 3186500 & Williams River at Dyer, WV & 332 \\
\hline $3 \mathrm{~K}$ & Kanawha & 3187500 & Cranberry River near Richwood, WV & 208 \\
\hline $4 \mathrm{~K}$ & Kanawha & 3198500 & Big Coal River at Ashford, WV & 1013 \\
\hline $5 \mathrm{~K}$ & Kanawha & 3179000 & Bluestone River at Durbin, WV & 1020 \\
\hline $6 \mathrm{~K}$ & Kanawha & 3183500 & Greenbrier River at Alderson, WV & 3533 \\
\hline $1 \mathrm{~T}$ & Tennessee & 348800 & North Fork Holston River near Saltsville, VA & 575 \\
\hline $2 \mathrm{~T}$ & Tennessee & 3528000 & Clinch River above Tazewell, TN & 3818 \\
\hline $3 \mathrm{~T}$ & Tennessee & 3497300 & Little River above Townsend, TN & 275 \\
\hline $4 \mathrm{~T}$ & Tennessee & 3500000 & Little Tennessee River near Pretniss, NC & 363 \\
\hline $1 \mathrm{P}$ & Potomac & 1601500 & Wills Creek near Cumberland, MD & 640 \\
\hline $2 \mathrm{P}$ & Potomac & 1610000 & Pototmac River near Great Cacapon, WV & 8052 \\
\hline $3 \mathrm{P}$ & Potomac & 1611500 & Cacapon River near Great Cacapon, WV & 1753 \\
\hline $4 \mathrm{P}$ & Potomac & 1604500 & Patterson Creek near Headsville, VS & 567 \\
\hline $5 \mathrm{P}$ & Potomac & 1643500 & Bennett Creek at Park Mills, MD & 163 \\
\hline & & & South Branch Potoamc River near & \\
\hline $6 \mathrm{P}$ & Potomac & 1608500 & Springfield, WV & 3810 \\
\hline $7 \mathrm{P}$ & Potomac & 1614500 & Conococheague Creek and Fairview, MD & 1279 \\
\hline $8 \mathrm{P}$ & Potomac & 1617800 & Marsh Run at Grimes, MD & 49 \\
\hline
\end{tabular}




\begin{tabular}{llllr} 
9P & Potomac & 1595000 & North Branch Potomac River at Steyer, MD & 189 \\
$10 \mathrm{P}$ & Potomac & 1637500 & Catoctin Creek near Middletown, MD & 173 \\
$11 \mathrm{P}$ & Potomac & 1644000 & Goose Creek near Leesburg, VA & 860 \\
& & & North Fork Shenandoah River at Cootes \\
$12 \mathrm{P}$ & Potomac & 1632000 & Store, VS \\
$13 \mathrm{P}$ & Potomac & 1634500 & Cedar Creek near Winchester, VA & 544 \\
\hline
\end{tabular}


Gaertner, B.A. Zegre, N. 2019. Spatial variations, trends, and drivers in evapotranspiration changes across the central Appalachian Mountains, United States. Journal of American Water Resources.

\begin{abstract}
This study examined the regional and local spatial relationships between climate variables and evapotranspiration (ET) trends throughout the central Appalachian region. Regional and local $\left(4 \mathrm{~km}^{2}\right)$ drivers of ET including temperature, precipitation, dew point temperature, and vapor pressure deficit were determined using an ordinary least squares and geographically weighted regression model. Throughout the central Appalachian region, precipitation, temperature, and vapor pressure deficit were found to have the most significant relationship with ET. At the $4 \mathrm{~km}^{2}$ scale, vapor pressure deficit was found to have the strongest relationship. The relationship between ET, precipitation, and temperature underscores the importance of evaporative atmospheric demand (temperature) and water input (precipitation) required for the evapotranspiration processes. ET at the local scale is largely driven by competing forces that are increasing ET (such as a longer growing season and higher vapor pressure deficit,) and biological processes that decrease ET (such as water use efficiency and drought stress mechanisms.) ET trends did not significantly change throughout the region from 2000-2015, suggesting that there are even more complicated competing factors influencing ET. Understanding the underlying biological and physical ET processes provides insight into future water resources.
\end{abstract}

\title{
4.1 INTRODUCTION
}

Forests play an important role in global water cycling (Ellison et al. 2017) but climate change has altered the partitioning of precipitation $(\mathrm{P})$ into evaporation $(\mathrm{ET})$ and runoff $(\mathrm{Q})$ (Asadieh and Krakauer 2015) by changing energy and water fluxes through intensification of the water cycle (Huntington 2010). ET is important for regulating the water budget, reducing streamflow and runoff fluxes, maintaining forest and soil health, and providing ecosystem productivity (Rodriguez-Iturbe 2000). Climate change has increased ET fluxes worldwide through intensification of the water cycle due to greater energy demand (Huntington 2006) but the underlying processes that drive changes in ET at smaller spatial scales are not completely 
understood. Numerous confounding factors such growing season length (Hwang et al. 2014, Kim et al. 2018, Gaertner et al. 2019), water availability, energy demand (Budyko 1974), and forest structure (e.g. species, age, productivity) (Caldwell et al. 2016) interact to influence net ET. Changes in ET are, therefore, a function of complex global drivers and multifaceted climatic processes (Fernandez and Zegre 2019), and understanding ET trends and processes is necessary for protecting and managing future water security (Ford et al. 2005).

ET varies spatially and temporally but overall it has increased globally (Jung et al. 2010, Zeng et al. 2012) and continentally in the United States (Lawrimore and Peterson 2000, Szilagyi et al. 2001, Hobbins et al. 2004, Walter et al. 2004). Notwithstanding, regional trends are complex and more variable, owing to dependence on local landscape factors such as forest cover, climatic conditions including P availability and PET demand, and topographic drivers such as orographic lift (Fernandez and Zegre 2019). ET in the northeastern and southeastern United States has increased (Burns et al. 2007, Cruise et al. 2010, Feng et al. 2016) while ET in some areas of the mid-Atlantic (Pennsylvania, Ohio, West Virginia) has decreased (Vadeboncoeur et al. 2018). The Appalachian Mountains region, comprised largely of West Virginia and portions of surrounding states (e.g. PA, OH, KY, TN, NC), is situated between the NE and SE regions that have disparate direction and magnitude of changes. Given the importance of the Appalachian Mountain region in provisioning streamflow to cities in the Mississippi River and Atlantic basins, it is critical to quantify ET loss and identify the drivers of ET in this region.

Growing season length influences ET processes and has been shown to partially control ET trends in the central Appalachian region. Studies have shown that over recent decades growing season has arrived earlier in general in temperate forests (Chmielewski and Rötzer 2001, Richardson et al. 2006, Schwartz et al. 2006, Lebourgeois et al. 2010, Jeong et al. 2011, Creed et al. 2015, Gaertner et al. 2019). In the central Appalachian region, growing season length has increased by 22 days from 1982-2012 (Gaertner et al. 2019). Growing season control of ET trends varies geographically. In the eastern United States, a one day increase in growing season length increases ET by $1 \mathrm{~mm} /$ year (White et al. 1999), in the southeastern United States (North Carolina), a one day increase in growing season increased ET by $4.3 \mathrm{~mm} / \mathrm{year}$ (Hwang et al. 2014, Hwang et al. 2018, Kim et al. 2018), and in the central Appalachian region, ET increases 0.5-0.7 $\mathrm{mm}$ per one day increase in growing season length (Gaertner et al. 2019). Therefore, 
understanding the spatial relationship between climatic/biophysical and ET trends in the central Appalachian region will provide insight to relevant ET drivers.

Greater rates of ET occur in response to increasing atmospheric and evaporative demand. A warming climate will increase energy demand via vapor pressure deficit (Donohue et al. 2010, Gaertner et al. 2019), which results in higher ET (Williams and Baeza 2007, Will et al. 2013). Intensification of the water cycle has increased evapotranspiration fluxes, which has increased the frequency and intensity of storm systems (Karl and Knight 1998). However, higher atmospheric $\mathrm{CO}_{2}$ concentration can counteract the increasing ET trends since stomata tend to close in response to increasing atmospheric $\mathrm{CO} 2$ concentration, which limits ET water loss (Kirschbaum 2004). Many of the climatic and hydrologic processes are regionally and locally controlled, which increases the complexity of the system.

The overall objective of this paper is to understand how the climate and ET has changed across central Appalachian Mountains region, to provide insight to the spatial relationship between regional trends and the influence of drivers on ET trends. In exploring these issues, the following objectives are explored

1. Quantify climate and ET components in recent history to understand the implications of change on water resource sustainability

2. Determine climate drivers important to evapotranspiration drivers across the region

3. Evaluate the primary drivers of local evapotranspiration processes

\subsection{METHODS}

\subsubsection{Study Area}

Our study area consisted of 31 catchments within five river basins located in the eastern United States that collectively cover $125,000 \mathrm{~km}^{2}$ (Figure 1). Four river basins (Monongahela, Upper Ohio, Kanawha, and Tennessee) drain west to the Mississippi River and Gulf of Mexico, one basin (Potomac) drains east to Washington D.C. and the Chesapeake Bay. The 31catchments selected for this study are part the U.S. Geological Survey Hydro-Climatic Data Network (HCDN) (Slack and Landwehr 1992), which consists of streamflow station data for minimally impacted watersheds ( $<10 \%$ human influence such as reservoirs, diversions, land use change, or severe ground-water pumping). Regional land cover analysis using data from the 2011 National Land Cover Database (NLCD) (Homer et al. 2015) was used to verify that catchments met the 
HCDN definition. The HCDN watersheds included seven catchments in the Kanawha basin, five catchments in the Monongahela basin, two catchments in the Upper Ohio basin, thirteen catchments in the Potomac Basin, and four catchments in the Tennessee basin (Table 1). Collectively, the HCDN catchments covered approximately $40 \%$ of the total area within the five river basins.

The forests of the region are mostly classified as mixed mesophytic, dominated by various hardwood species (e.g. Quercus (oaks), Betula (birch), Fagus (birch), Acer (maple), Populus (poplar)) located on ridges and hillslopes, and coniferous species such as Pinus (pine) and Tsuga (hemlock) at higher elevations and along stream networks (Day et al. 1988, Slayer 2014). The region's climate is characterized as humid marine in the eastern/Atlantic coastal area and humid continental on the western edge (Konrad and Fuhrmann 2013). Mean annual temperature ranges from $9.3^{\circ} \mathrm{C}$ in the mountains to $14.7^{\circ} \mathrm{C}$ near the Atlantic coast, and increases with decreasing latitude. Long-term (1981-2010) air temperatures in the northernmost Ohio River basin average $10.5^{\circ} \mathrm{C}$, and $15^{\circ} \mathrm{C}$ in the southernmost Tennessee River basin (Daly et al. 1997). $P$ is relatively evenly distributed throughout the year, dominated by small, low intensity storms with intermittent high intensity frontal thunderstorm events (Keim 1996, 1997, Konrad and Fuhrmann 2013). Annual $\mathrm{P}$ increases with elevation, ranging from $1034 \mathrm{~mm}$ in the Potomac River near the coast, to $1870 \mathrm{~mm}$ in the mountains of the Tennessee River basin. Average annual ET loss is $\sim 75 \%$ of annual rainfall in all catchments except the Monongahela, where ET $\sim 51 \%$ of P. (Miller and Weaver 1971, Farnsworth and Thompson 1983, Harstine 1991, Ford et al. 2005, Adams et al. 2012).

\subsubsection{Datasets}

Annual evapotranspiration (2000-2013) was extracted for the study region from the dataset of Reitz et al. (2017) that provides gridded (800 m) ET, quick flow runoff, and recharge for the conterminous USA. Data provided by Reitz et al. (2017)) were developed from an empirical regression relationship of water balance data, land cover, precipitation, and temperature.

Climate variables important to ET, such as monthly precipitation $[\mathrm{P}]$, maximum temperature [Tmax], minimum temperature [Tmin], mean temperature [Tmean], mean dew point temperature [DPT], minimum vapor pressure deficit, $\left[\mathrm{VPD}_{\min }\right]$ and maximum vapor pressure 
deficit $\left[V D_{\max }\right]$ were extracted at a $4 \mathrm{~km}^{2}$ spatial scale from PRISM (Daly et al. 1997). ET was aggregated on an annual basis while all other variables were aggregated to growing season months from April-October following the analysis by Gaertner et al. (2019)), who found that growing season extended on average from April $17^{\text {th }}$ to October $13^{\text {th }}$, throughout the central Appalachian Mountains region. Using the growing season time period is important for studying evapotranspiration the central Appalachian region, since the greatest ET fluxes occur during the leaf on period (Troch et al. 2009).

\subsubsection{Statistical Methods}

\subsubsection{Trend Analysis}

The rank-based, non-parametric Mann Kendall statistical test was used to detect trends in climate and water balance variables (Helsel and Hirsch 1992). Mann Kendall allows for both non-normally distributed data (Andreadis and Lettenmaier 2006) and missing values (Hirsch and Slack 1984), and is commonly used for detecting trends in hydrology and hydro-meteorological studies (Yue et al. 2002). Trends were considered significant at the $\alpha=0.1$ level. The direction and magnitude of trends was estimated using the Sen slope, calculated as the median slope among all lines through a time series (Helsel and Hirsch 1992).

A LOESS (locally weighted scatter-plot smoother) curve was fitted to all evapotranspiration data from 2000-2013 using a 95\% confidence boundary to identify interannual trends (Hirsch and Slack 1984).

\subsubsection{Regression Model}

A global regression equation that incorporated all data into the analysis was developed using the Ordinary Least Squares (OLS) tool in ArcGIS (Hamilton 1992, Mitchel 2005). The OLS global regression analysis was used to determine the relationship between climate and ET variables across the entire study area, which provided information on the effect large-sale climatic variation on ET changes. The ordinary least squares tool creates a single regression equation based on the relationship between predictor and response variables. In this study, we used the seven climate variables as predictors of ET. All variables were determined normally distributed and independent based on histograms. Six model components were evaluated for properly specified model structure. First, a Moran's I test was conducted to confirm model 
residuals were not clustered in location (Getis and Ord 2010). Second, Jarque-Bera test was confirmed insignificant $(\alpha>0.05)$ to verify that model residuals were not clustered in value (Jarque and Bera 1980). Third, The Variance Inflation Factor (VIF) was confirmed below 7.5 to account for multicollinearity of model variables (Marquaridt 1970). Fourth, the adjusted $\mathrm{R}^{2}$ evaluated model fit, with values greater than 0.6 suggesting high model fit and performance (Helsel and Hirsch 1992). Fifth, the regression direction was determined based on the coefficient [a] sign, and evaluated based hypothesis expectations. Finally, model variables were considered significant at alpha $=0.1$.

The model that passed the six criteria were evaluated in a Geographically Weighted Regression (GWR) in ArcMap (Fotheringham et al. 2003). The GWR output was evaluated to determine the relationship between climate and ET variables at a local $4 \mathrm{~km}^{2}$ scale, which provided insight into the effect of ecosystem level climatic variations on ET change. GWR uses ordinary least squares regression in kernel-weighted regression. Using this computation, the GWR produced a global $\mathrm{R}^{2}$ for the model and local $\mathrm{R}^{2}$ values for every $4 \mathrm{~km}^{2}$ pixel value. $\mathrm{R}^{2}$ and AICc values were used to evaluate model fit, with an $\mathrm{R}^{2}$ of greater than 0.6 and low AICc values representing high model fit. Following implementation of the GWR, the data were interpolated using an ordinary Kriging spatial interpolation method (Oliver and Webster 1990) to develop a continuous spatial regression map.

\subsection{Results}

\subsubsection{Trend Analysis}

Growing season P ranged from 946 to $1376 \mathrm{~mm}$ and averaged $1030 \mathrm{~mm}$ across all catchments (Table 2; Figure 2). Trends in P were note significant in any of the catchments (Table 3). Growing season ET ranged from $348 \mathrm{~mm}$ (Potomac) to $1043 \mathrm{~mm}$ (Tennessee), averaging 678 $\mathrm{mm}$, but similar to $\mathrm{P}$, trends in ET were not significant. Maximum temperatures throughout the region ranged from 21 to $26^{\circ} \mathrm{C}$ and averaged $23.6^{\circ} \mathrm{C}$ across all catchments, but trends were not significant. Average temperatures ranged from 17 to $23^{\circ} \mathrm{C}$ and averaged $20.26^{\circ} \mathrm{C}$, but trends were not significant. Minimum temperatures significantly increased in 10 of the catchments (Table 2), including one in Ohio, one in the Kanawha basin, and 8 in the Potomac basin. Dew point temperatures ranged from 9 to $13^{\circ} \mathrm{C}$ and averaged $10.6^{\circ} \mathrm{C}$. DPT significantly increased in only one catchment by $0.09^{\circ} \mathrm{C}$ in the Kanawha basin. 
Maximum vapor pressure deficit ranged from 12 to $19 \mathrm{hPa}$ and averaged $15.95 \mathrm{hPa}$. VPD significantly increased in four catchments with three in the Kanawha and one in the Tennessee. Minimum vapor pressure deficit ranged from 0 to $1 \mathrm{hPa}$ and averaged $0.74 \mathrm{hPa}$, increasing significantly in four catchments, two of which were in the Kanawha basin and two in the Ohio basin (Table 2).

\subsubsection{Regression Model}

The global OLS model with the greatest model fit and performance identified three of the seven explanatory variables as significant for explaining ET across the region (Table 4); minimum vapor pressure deficit, minimum temperature, and precipitation. The model passed the all six model fit criteria except the morains I test. Figure 3 represents the spatial clustering of values based on the standard residuals of the model. Under prediction appeared to occur around the large population centers of Washington D.C. (Potomac basin) and Pittsburgh (Monongahela basin). Over prediction appeared to occur near water bodies including the Chesapeake Bay (Potomac basin) and the Tennessee river system (Tennessee basin). Much of the clustering does not occur in our HCDN watersheds and therefore, should not affect of the overall catchment results.

The geographically weighted regression identified the greatest local $\left(4 \mathrm{~km}^{2}\right)$ correlation between ET and minimum vapor pressure deficit $\left(\mathrm{R}^{2}=0.68\right)$ (Figure 4$)$. The relationship between VPDmin and ET was greatest in the Ohio and Monongahela basin.

\subsection{Discussion}

\section{Changes in regional climate and water balance components}

Long term records (1890-2000) show that temperatures have increased throughout the Appalachian Mountains region by between $0.5-1.9^{\circ} \mathrm{C}$ (Ford et al. 2011, Pitchford et al. 2011, Laseter et al. 2012, Patterson et al. 2012). Long-term records show greater increases in minimum temperatures in some regions (Hayhoe et al. 2006, Burns et al. 2007) and greater change in maximum temperatures in other regions of the eastern US (Wu et al. 2012). In the central Appalachian region, minimum temperatures have increased more significantly than average or maximum temperatures. This pattern likely indicates that minimum temperatures are increasing 
greatest during the growing season while maximum temperatures in nearby regions are increasing on a long-term annual basis.

Long-term (1984-2012) precipitation records throughout the southeastern Appalachian region show that growing season (March-November) precipitation has increased by 3-7\% (Crane and Hewitson 1998, Wu et al. 2014), which is similar to the P changes in the central Appalachian region, which averaged a 5.5\% increase from 2000-2013 (Table 3). Though this trend is similar, the time period is shorter, more recent, and insignificant. One explanation for the lack of significant trends is an extreme (D3) drought that occurred throughout the central Appalachian region in 2008-2009 (drought.gov), which resulted in a sharp decline in rainfall (Figure 5) in 2008. Although the rainfall pattern returned to normal after 2009, the precipitous drop influenced the overall trend.

Long-term (1950-2005) evapotranspiration records throughout the northeastern United States has increased from 0.5-3.2 mm/yr (Hayhoe et al. 2006, Burns et al. 2007, Campbell et al. 2009), while the southern Appalachian ET has increased by $5.7 \mathrm{~mm}$ per year from 1992-2011, (Kim et al. 2018). All of these trends were higher than those detected for the central Appalachian region, which averaged $0.5 \mathrm{~mm} /$ year. We believe there are several reasons for the lack of significant trends in the central Appalachian region when compared to nearby regions, including the competing climatic and landscape controls such as vapor pressure deficit, growing season length increases, atmospheric $\mathrm{CO}_{2}$ concentration, and vegetation species response changing climate. First, increasing vapor pressure deficit increases ET rates due to greater temperature and atmosphere energy demands (Dingman 2002). Second, average growing season has increased 22 days from 1982-2012 in the region (Gaertner et al. 2019), which has increased evapotranspiration by 0.5-4.5 mm (White et al. 1999, Hwang et al. 2014, Kim et al. 2018). Third, $\mathrm{CO}_{2}$ concentration decreases ET rates due to increased plant water use efficiency (Warren et al. 2011). Fourth, vegetation in temperate deciduous forests have developed preventative drought stress stomatal dynamics that can reduce evapotranspiration rates during periods of reduced rainfall (Roman et al. 2015). Lastly, the 2008 drought resulted in a sharp decline in evapotranspiration (Figure 5), which reduced the trend from 2000-2013. However, the lack of significant trends does not discount the importance of understanding climatic and biophysical drivers of ET variations. 


\subsubsection{Regional and local Evapotranspiration drivers}

Regionally, ET changes are most correlated with minimum temperature, precipitation, and minimum vapor pressure deficit, suggesting that water and energy availability are the primary drivers of ET fluxes during the growing season. The ET climate drivers in the central Appalachian region are similar to ET drivers globally and regionally (Del Grosso et al. 2008, Vicente-Serrano et al. 2010). For example, globally, precipitation and temperature were found to have a high correlation with net primary productivity, which is often used as a proxy of evapotranspiration (Del Grosso et al. 2008). Similarly, a correlation analysis between climate variables and ET conducted by Vadeboncoeur et al. (2018) in the Northeastern United States found that regional annual precipitation and local temperatures were the primary climatic drivers of ET variations from 1940-2012. Another model identified precipitation and temperature as the primary climatic factors necessary for drought index modelling, a proxy for evapotranspiration, indicating that evapotranspiration increases with higher atmospheric and water demand (VicenteSerrano et al. 2010). Our OLS model, therefore, is consistent with global and regional evapotranspiration regression and multivariate models that suggest that water availability and atmospheric energy demand are important climate variables for understanding evapotranspiration trends at the regional scale.

Regional evapotranspiration processes can be explained by precipitation input and solar radiation/temperature patterns. In the central Appalachian region, precipitation input patterns follow geographical features such as orographic lift and rain shadow effect of the prevailing westerly winds, as well as large scale drivers including cyclones and the polar jet stream. Orographic effects over the Appalachian Mountains result in higher precipitation on the western facing slopes of the Appalachian Mountains and generally decrease on the eastern facing slopes due to the rain shadow effect of the prevailing westerly winds (Pitchford et al. 2011, Siler et al. 2013). Large scale cyclones in the Atlantic ocean are responsible for high intensity rainfall input in the lower central Appalachian catchments in Tennessee during the late growing season months (August and September) (Kam et al. 2013). Similarly, the polar jet stream is responsible for large-scale frontal systems from the mid-west and northern United States, which brings intense precipitation input in the northern portion of the region.

While atmospheric water supply is responsible for the amount of water available for evapotranspiration at the land surface, atmospheric energy demand is responsible for 
evapotranspiration losses. Solar radiation and temperature are largely dependent on elevation and latitude. Regional scale evapotranspiration rates are greatest at low latitudes, low elevation, and near the coast since these areas have higher air temperatures (Pitchford et al. 2011, Wu et al. 2012), greater atmospheric energy demand, and greater water availability.

At a local scale $\left(4 \mathrm{~km}^{2}\right)$, vapor pressure deficit is the most significant climatic predictor of evapotranspiration. VPD is the driving force that causes net movement of water from an evaporating surface such as a leaf surface to the atmosphere (Brooks et al. 2003), which increases with greater temperatures (Williams and Baeza 2007, Will et al. 2013). VPD was found to be highly correlated with ET in the southern portion of the Ohio and portions of the Monongahela basins which correspond to regions with increasing growing length as determined by Gaertner et al. (2019). Given that VPD exerts a dominant control on the transpiration component of ET in the forested basins (Jasechko et al. 2013) and growing season length changes have increased ET up to $0.5 \mathrm{~mm}$ in this region, these results suggest that local variations in ET in this region may be more complex than water and energy controls.

\subsubsection{Implications of climate change on evapotranspiration}

Higher temperatures have led to greater precipitation and evapotranspiration fluxes following intensification of the hydrologic cycle (Huntington 2010). Future temperatures are expected to continue to rise throughout the region by $>1{ }^{\circ} \mathrm{C}$ by 2099 (Powell and Keim 2015), which is expected to result in greater precipitation and evapotranspiration fluxes and streamflow throughout the region. Changes to large-scale drivers that influence precipitation under normal conditions such as coastal cyclones and the polar jet stream will result in greater precipitation extremes. Tropical cyclones in the Atlantic ocean are expected to increase in intensity but decrease in frequency, which is expected to bring more high intensity storms and less predictable rainfall during the growing season (Fernandez and Zegre 2019). Furthermore, the polar jet stream is expected to weaken and move to lower latitudes, which would block moisture from the Gulf of Mexico while increasing fronts from the northern US, potentially resulting in longer low intensity storms.

Higher temperatures are expected to increase evapotranspiration (Campbell et al. 2009) due to greater vapor pressure deficit and longer growing season length. Approximately $80 \%$ of ET comes from the transpiration component in terrestrial forested ecosystems (Jasechko et al. 
2013). This suggests that, in the central Appalachian region, greater temperatures may lead to greater ET in small scale forested ecosystems in the southern region (Tennessee basin), coastal regions (Potomac), and low elevation regions due to the high atmospheric energy and water availability. Furthermore, these regions have experienced a longer growing length by 22 days since 1982, and 30-70 days specifically in the forested basins. A longer growing season has the capability to increase evapotranspiration by $0.5-4.5 \mathrm{~mm}$ per 1 day increase in growing season length (Hwang et al. 2012, Hwang et al. 2014, Hwang et al. 2018, Gaertner et al. 2019), which can lead to reduced river discharge (Kim et al. 2018).

Growing season increases have been shown to counteract or even outweigh the increased $\mathrm{CO}_{2}$ concentration effects on water use efficiency (Frank et al. 2015), leading to an overall decrease in river discharge in broadleaf and coniferous forests. Recent research using a processbased model has indicated that future discharge is likely to increase in the central Appalachian given future climatic changes such as increased temperatures, precipitation, and potential evapotranspiration (Gaertner, 2019). Mechanistic models have identified that the south eastern United States will likely have increasing future discharge, given climatic, hydrologic, and land use changes (Wu et al. 2012). This suggests that, despite increasing water use efficiency, evapotranspiration responses to changing climate may lead greater discharge

\subsection{Conclusion}

Precipitation and temperature are important drivers of evapotranspiration fluxes at the global and regional scale. In the central Appalachian region, precipitation was most highly correlated with ET variables in the Potomac basin, which is the driest basin in the region, suggesting that this basin is more water limited than the other basins the region. Within the study area, the Potomac basin is the most limited by water availability and has the greatest sensitivity to climate change, suggesting a lower capacity to buffer climate variations. On the other hand, the wet, mountainous basins have a lower sensitivity to climate, suggesting a capability to absorb extreme fluctuations in climate such as drought and flooding through species and landscape level evapotranspiration physiological mechanisms. Therefore, ecosystems with a lower sensitivity to climate change will likely also experience lower evapotranspiration as physiological mechanisms adapt water use efficiency to the changes, suggesting a possible future reduction in streamflow. 
Locally, vapor pressure deficit represents an important driver of evapotranspiration fluxes, especially in the forested basins, suggesting that vapor pressure deficit exhibits and important control on the transpiration component of ET, which leads to higher ET in the temperate forests. Research has also shown that vapor pressure deficit in combination with other atmospheric water variables is important for signaling an earlier growing season (Gaertner et al. 2019), which has led to a growing season up to 70 days in parts of the Central Appalachian temperate forests. Longer growing season lengths can increase evapotranspiration and lead to an overall decrease in river flow.

Therefore, atmospheric demand for water may not fully explain ET variations, as species level physiological mechanisms in response to as water balance components may alter ET fluxes. However, other research has identified that growing season length controls on ET may counteract or override climate controls, suggesting an overall future increase in river discharge. 


\section{REFERENCES:}

Abatzoglou, J. T., and T. J. Brown. 2012. A comparison of statistical downscaling methods suited for wildfire applications. International journal of climatology 32:772-780.

Abildtrup, J., S. Garcia, and A. Stenger. 2013. The effect of forest land use on the cost of drinking water supply: A spatial econometric analysis. Ecological Economics 92:126136.

Adams, M. B., P. J. Edwards, W. M. Ford, T. M. Schuler, M. Thomas-Van Gundy, and F. Wood. 2012. Fernow experimental forest: research history and opportunities.

Allen, M. R., and W. J. Ingram. 2002. Constraints on future changes in climate and the hydrologic cycle. Nature 419:224-232.

Andreadis, K. M., and D. P. Lettenmaier. 2006. Trends in 20th century drought over the continental United States. Geophysical Research Letters 33.

ARC. 1970. Subregions in Appalachia. Appalachian Regional Commission.

Arnold, T. W. 2010. Uninformative parameters and model selection using Akaike's Information Criterion. Journal of Wildlife Management 74:1175-1178.

Asadieh, B., and N. Krakauer. 2015. Global trends in extreme precipitation: climate models versus observations. Hydrology and Earth System Sciences 19:877-891.

Bartoń, K. 2013. MuMIn: Multi-model inference. R package version 1.9. 13. The Comprehensive R Archive Network (CRAN), Vienna, Austria.

Bates, B., Z. W. Kundzewicz, S. Wu, and J. Palutikof. 2008. climate change and Water: technical Paper vi. Intergovernmental Panel on Climate Change (IPCC).

Bauerle, W. L., R. Oren, D. A. Way, S. S. Qian, P. C. Stoy, P. E. Thornton, J. D. Bowden, F. M. Hoffman, and R. F. Reynolds. 2012. Photoperiodic regulation of the seasonal pattern of photosynthetic capacity and the implications for carbon cycling. Proceedings of the National Academy of Sciences 109:8612-8617.

Bibby, J., J. Kent, and K. Mardia. 1979. Multivariate analysis. Academic Press, London.

Bondeau, A., P. C. Smith, S. Zaehle, S. Schaphoff, W. Lucht, W. Cramer, D. Gerten, H. LOTZECAMPEN, C. Müller, and M. Reichstein. 2007. Modelling the role of agriculture for the 20th century global terrestrial carbon balance. Global Change Biology 13:679-706.

Breckling, J. 2012. The analysis of directional time series: applications to wind speed and direction. Springer Science \& Business Media.

Brooks, K. N., P. F. Ffolliott, H. M. Gregersen, and L. F. DeBano. 2003. Hydrology and the management of watersheds. Iowa State University Press.

Brzostek, E. R., D. Dragoni, H. P. Schmid, A. F. Rahman, D. Sims, C. A. Wayson, D. J. Johnson, and R. P. Phillips. 2014. Chronic water stress reduces tree growth and the carbon sink of deciduous hardwood forests. Glob Chang Biol 20:2531-2539.

Budyko, M. 1974. Climate and Life, 508 pp. Academic, San Diego, Calif:72-191.

Budyko, M. I. 1961. The heat balance of the earth's surface. Soviet Geography 2:3-13.

Burkett, V. 2011. Global climate change implications for coastal and offshore oil and gas development. Energy Policy 39:7719-7725.

Burns, D. A., J. Klaus, and M. R. McHale. 2007. Recent climate trends and implications for water resources in the Catskill Mountain region, New York, USA. Journal of Hydrology 336: $155-170$.

Caldwell, P., C. Muldoon, C. Ford-Miniat, E. Cohen, S. Krieger, G. Sun, S. McNulty, and P. V. Bolstad. 2014. Quantifying the role of National Forest System lands in providing surface drinking water supply for the southern United States. 
Caldwell, P., G. Sun, S. McNulty, E. Cohen, and J. M. Myers. 2012. Impacts of impervious cover, water withdrawals, and climate change on river flows in the conterminous US.

Caldwell, P. V., C. F. Miniat, K. J. Elliott, W. T. Swank, S. T. Brantley, and S. H. Laseter. 2016. Declining water yield from forested mountain watersheds in response to climate change and forest mesophication. Global Change Biology 22:2997-3012.

Campbell, J. L., C. T. Driscoll, A. Pourmokhtarian, and K. Hayhoe. 2011. Streamflow responses to past and projected future changes in climate at the Hubbard Brook Experimental Forest, New Hampshire, United States. Water Resources Research 47:W02514.

Campbell, J. L., L. E. Rustad, E. W. Boyer, S. F. Christopher, C. T. Driscoll, I. J. Fernandez, P. M. Groffman, D. Houle, J. Kiekbusch, and A. H. Magill. 2009. Consequences of climate change for biogeochemical cycling in forests of northeastern North America This article is one of a selection of papers from NE Forests 2100: A Synthesis of Climate Change Impacts on Forests of the Northeastern US and Eastern Canada. Canadian Journal of Forest Research 39:264-284.

Campbell, R. J. 2012. Weather-related power outages and electric system resiliency. Congressional Research Service, Library of Congress Washington, DC.

Canadell, J., R. Jackson, J. Ehleringer, H. Mooney, O. Sala, and E.-D. Schulze. 1996. Maximum rooting depth of vegetation types at the global scale. Oecologia 108:583-595.

Chapin, F. S. 1977. Nutrient/carbon costs associated with tundra adaptations to a cold nutrientpoor environment. Pages 1183-1194 in Proc. Circumpolar Conference on Northern Ecology. Nat Res Council of Canada, Ottawa.

Chapin, F. S., J. McKendrick, and D. Johnson. 1986a. Seasonal changes in carbon fractions in Alaskan tundra plants of differing growth form: implications for herbivory. The Journal of Ecology:707-731.

Chapin, F. S., G. Shaver, and R. Kedrowski. 1986b. Environmental controls over carbon, nitrogen and phosphorus fractions in Eriophorum vaginatum in Alaskan tussock tundra. The Journal of Ecology:167-195.

Chapin III, F. S., E. Schulze, and H. A. Mooney. 1990. The ecology and economics of storage in plants. Annual Review of Ecology and Systematics 21:423-447.

Chmielewski, F.-M., and T. Rötzer. 2001. Response of tree phenology to climate change across Europe. Agricultural and Forest Meteorology 108:101-112.

Chou, C., J. D. Neelin, C.-A. Chen, and J.-Y. Tu. 2009. Evaluating the "rich-get-richer" mechanism in tropical precipitation change under global warming. Journal of Climate 22:1982-2005.

Choudhury, B. 1999. Evaluation of an empirical equation for annual evaporation using field observations and results from a biophysical model. Journal of Hydrology 216:99-110.

Clausen, K. K., and P. Clausen. 2013. Earlier Arctic springs cause phenological mismatch in long-distance migrants. Oecologia 173:1101-1112.

Cooper, M., J. Schaperow, S. Cooley, S. Alam, L. Smith, and D. Lettenmaier. 2018. Climate Elasticity of Low Flows in the Maritime Western US Mountains. Water Resources Research 54:5602-5619.

Coopersmith, E., M. Yaeger, S. Ye, L. Cheng, and M. Sivapalan. 2012. Exploring the physical controls of regional patterns of flow duration curves-Part 3: A catchment classification system based on regime curve indicators. Hydrology and Earth System Sciences 16:44674482 . 
Crane, R. G., and B. C. Hewitson. 1998. Doubled CO2 precipitation changes for the Susquehanna basin: down-scaling from the GENESIS general circulation model. International journal of climatology 18:65-76.

Creed, I., T. Hwang, B. Lutz, and D. Way. 2015. Climate warming causes intensification of the hydrological cycle resulting in changes to the vernal and autumnal windows in a northern temperate forest. Hydrological Processes.

Creed, I. F., G. Z. Sass, J. M. Buttle, and J. A. Jones. 2011. Hydrological principles for sustainable management of forest ecosystems. Hydrological Processes:n/a-n/a.

Creed, I. F., A. T. Spargo, J. A. Jones, J. M. Buttle, M. B. Adams, F. D. Beall, E. G. Booth, J. L. Campbell, D. Clow, K. Elder, M. B. Green, N. B. Grimm, C. Miniat, P. Ramlal, A. Saha, S. Sebestyen, D. Spittlehouse, S. Sterling, M. W. Williams, R. Winkler, and H. Yao. 2014. Changing forest water yields in response to climate warming: results from longterm experimental watershed sites across North America. Glob Chang Biol 20:31913208.

Cruise, J. F., C. A. Laymon, and O. Z. Al-Hamdan. 2010. Impact of 20 Years of Land-Cover Change on the Hydrology of Streams in the Southeastern United States. JAWRA Journal of the American Water Resources Association 46:1159-1170.

Daly, C., M. Halbleib, J. I. Smith, W. P. Gibson, M. K. Doggett, G. H. Taylor, J. Curtis, and P. P. Pasteris. 2008. Physiographically sensitive mapping of climatological temperature and precipitation across the conterminous United States. International journal of climatology 28:2031-2064.

Daly, C., G. Taylor, and W. Gibson. 1997. The PRISM approach to mapping precipitation and temperature. Pages 20-23 in Proc., 10th AMS Conf. on Applied Climatology.

Day, F., D. Phillips, and C. Monk. 1988. Forest communities and patterns. Pages 141-149 Forest hydrology and ecology at Coweeta. Springer.

Del Grosso, S., W. Parton, T. Stohlgren, D. Zheng, D. Bachelet, S. Prince, K. Hibbard, and R. Olson. 2008. Global potential net primary production predicted from vegetation class, precipitation, and temperature. Ecology 89:2117-2126.

Delpla, I., A.-V. Jung, E. Baures, M. Clement, and O. Thomas. 2009. Impacts of climate change on surface water quality in relation to drinking water production. Environment International 35:1225-1233.

DeWalle, D. R., B. R. Swistock, T. E. Johnson, and K. J. McGuire. 2000. Potential effects of climate change and urbanization on mean annual streamflow in the United States. Water Resources Research 36:2655-2664.

Dingman, S. L. 2002. Physical Hydrology. 2 edition. Prentice Hall, Upper Saddle River, NJ.

Dingman, S. L. 2015. Physical hydrology. Waveland press.

Donohue, R. J., T. R. McVicar, and M. L. Roderick. 2010. Assessing the ability of potential evaporation formulations to capture the dynamics in evaporative demand within a changing climate. Journal of Hydrology 386:186-197.

Donohue, R. J., M. L. Roderick, and T. R. McVicar. 2012. Roots, storms and soil pores: Incorporating key ecohydrological processes into Budyko's hydrological model. Journal of Hydrology 436-437:35-50.

Dragoni, D., and A. F. Rahman. 2012. Trends in fall phenology across the deciduous forests of the Eastern USA. Agricultural and Forest Meteorology 157:96-105.

Dudley, N., and S. Stolton. 2003. Running pure: the importance of forest protected areas to drinking water. World Bank Publications. 
Eagleson, P. S. 1978. Climate, soil, and vegetation: 1. Introduction to water balance dynamics. Water Resources Research 14:705-712.

Ellison, D., C. E. Morris, B. Locatelli, D. Sheil, J. Cohen, D. Murdiyarso, V. Gutierrez, M. Van Noordwijk, I. F. Creed, and J. Pokorny. 2017. Trees, forests and water: Cool insights for a hot world. Global environmental change 43:51-61.

Estiarte, M., and J. Peñuelas. 2015. Alteration of the phenology of leaf senescence and fall in winter deciduous species by climate change: effects on nutrient proficiency. Global Change Biology 21:1005-1017.

Farnsworth, R. K., and E. S. Thompson. 1983. Mean monthly, seasonal, and annual pan evaporation for the United States. US Department of Commerce, National Oceanic and Atmospheric Administration, National Weather Service.

Feng, D., E. Beighley, R. Hughes, and D. Kimbro. 2016. Spatial and Temporal Variations in Eastern US Hydrology: Responses to Global Climate Variability. JAWRA Journal of the American Water Resources Association 52:1089-1108.

Fernandez, R., and T. Sayama. 2015. Hydrological recurrence as a measure for large river basin classification and process understanding. Hydrology and Earth System Sciences 19:19191942.

Fernandez, R., and N. Zegre. 2019. Seasonal changes in water and energy balances over the Appalachian region and beyond throughout the 21st century. Hydrologic Earth System Science in review.

Fitzjarrald, D. R., O. C. Acevedo, and K. E. Moore. 2001. Climatic consequences of leaf presence in the eastern United States. Journal of Climate 14:598-614.

Ford, C. R., C. E. Goranson, R. J. Mitchell, R. E. Will, and R. O. Teskey. 2005. Modeling canopy transpiration using time series analysis: a case study illustrating the effect of soil moisture deficit on Pinus taeda. Agricultural and Forest Meteorology 130:163-175.

Ford, C. R., S. H. Laseter, W. T. Swank, and J. M. Vose. 2011. Can forest management be used to sustain water-based ecosystem services in the face of climate change? Ecological Applications 21:2049-2067.

Fotheringham, A. S., C. Brunsdon, and M. Charlton. 2003. Geographically weighted regression. John Wiley \& Sons, Limited.

Frank, D., B. Poulter, M. Saurer, J. Esper, C. Huntingford, G. Helle, K. Treydte, N. Zimmermann, G. Schleser, and A. Ahlström. 2015. Water-use efficiency and transpiration across European forests during the Anthropocene. Nature Climate Change 5:579.

$\mathrm{Fu}, \mathrm{B} .-\mathrm{P} .1981$. on the calculation of the evaporation from land surface. Chinese Journal of Atmospheric Sciences 1:002.

Gaertner, B. A., N. Zegre, T. Warner, R. Fernandez, Y. He, and E. R. Merriam. 2019. Climate, forest growing season, and evapotranspiration changes in the central Appalachian Mountains, USA. Science of The Total Environment.

Gao, P., X.-M. Mu, F. Wang, and R. Li. 2011. Changes in streamflow and sediment discharge and the response to human activities in the middle reaches of the Yellow River. Hydrology and Earth System Sciences 15:1-10.

Gardner, W. 1983. Soil properties and efficient water use: an overview. Limitations to efficient water use in crop production:45-64. 
Gersonius, B., R. Ashley, A. Pathirana, and C. Zevenbergen. 2013. Climate change uncertainty: building flexibility into water and flood risk infrastructure. Climatic Change 116:411423.

Getis, A., and J. K. Ord. 2010. The analysis of spatial association by use of distance statistics. Pages 127-145 Perspectives on Spatial Data Analysis. Springer.

Glibert, P. M., R. Magnien, M. W. Lomas, J. Alexander, C. Tan, E. Haramoto, M. Trice, and T. M. Kana. 2001. Harmful algal blooms in the Chesapeake and coastal bays of Maryland, USA: comparison of 1997, 1998, and 1999 events. Estuaries 24:875-883.

Haddeland, I., D. B. Clark, W. Franssen, F. Ludwig, F. Voß, N. W. Arnell, N. Bertrand, M. Best, S. Folwell, and D. Gerten. 2011. Multimodel estimate of the global terrestrial water balance: setup and first results. Journal of Hydrometeorology 12:869-884.

Hamilton, L. C. 1992. Regression with graphics: A second course in applied statistics.

Harrison, I. J., P. A. Green, T. A. Farrell, D. Juffe-Bignoli, L. Sáenz, and C. J. Vörösmarty. 2016. Protected areas and freshwater provisioning: a global assessment of freshwater provision, threats and management strategies to support human water security. Aquatic Conservation: Marine and Freshwater Ecosystems 26:103-120.

Harstine, L. J. 1991. Hydrologic Atlas for Ohio: average annual precipitation, temperature, streamflow, and water loss for 50-year period, 1931-1980. Ohio Department of Natural Resources, Division of Water, Ground Water Resources Section.

Hayhoe, K., C. Wake, B. Anderson, X.-Z. Liang, E. Maurer, J. Zhu, J. Bradbury, A. DeGaetano, A. Stoner, and D. Wuebbles. 2008. Regional climate change projections for the Northeast USA. Mitigation and Adaptation Strategies for Global Change 13:425-436.

Hayhoe, K., C. P. Wake, T. G. Huntington, L. Luo, M. D. Schwartz, J. Sheffield, E. Wood, B. Anderson, J. Bradbury, A. DeGaetano, T. J. Troy, and D. Wolfe. 2006. Past and future changes in climate and hydrological indicators in the US Northeast. Climate Dynamics 28:381-407.

Held, I. M., and B. J. Soden. 2000. Water vapor feedback and global warming. Annual Review of Energy and the Environment 25:441-475.

Held, I. M., and B. J. Soden. 2006. Robust responses of the hydrological cycle to global warming. Journal of Climate 19:5686-5699.

Helsel, D. R., and R. M. Hirsch. 1992. Statistical Methods in Water Resources. Elsevier, Amsterdam.

Hirsch, R. M., and L. A. De Cicco. 2015. User guide to Exploration and Graphics for RivEr Trends (EGRET) and dataRetrieval: R packages for hydrologic data. 2328-7055, US Geological Survey.

Hirsch, R. M., and J. R. Slack. 1984. A Nonparametric Trend Test for Seasonal Data With Serial Dependence. Water Resour. Res. 20:727-732.

Hobbins, M. T., J. A. Ramírez, and T. C. Brown. 2004. Trends in pan evaporation and actual evapotranspiration across the conterminous US: Paradoxical or complementary? Geophysical Research Letters 31.

Homer, C., J. Dewitz, L. Yang, S. Jin, P. Danielson, G. Xian, J. Coulston, N. Herold, J. Wickham, and K. Megown. 2015. Completion of the 2011 National Land Cover Database for the conterminous United States-representing a decade of land cover change information. Photogrammetric Engineering \& Remote Sensing 81:345-354.

Hong, G., and Y. Zhang. 2006. Object-based change detection in high resolution image.in Proceedings of the ASPRS 2006 Annual Conference, Reno, Nevada. 
Hu, M. Q., F. Mao, H. Sun, and Y. Y. Hou. 2011. Study of normalized difference vegetation index variation and its correlation with climate factors in the three-river-source region. International Journal of Applied Earth Observation and Geoinformation 13:24-33.

Huntington, T. G. 2006. Evidence for intensification of the global water cycle: Review and synthesis. Journal of Hydrology 319:83-95.

Huntington, T. G. 2010. Climate Warming-Induced Intensification of the Hydrologic Cycle. advances in agronomy 109:1-53.

Huntington, T. G., and M. Billmire. 2014. Trends in precipitation, runoff, and evapotranspiration for rivers draining to the Gulf of Maine in the United States. Journal of Hydrometeorology 15:726-743.

Hwang, T., L. E. Band, C. F. Miniat, C. Song, P. V. Bolstad, J. M. Vose, and J. P. Love. 2014. Divergent phenological response to hydroclimate variability in forested mountain watersheds. Global Change Biology 20:2580-2595.

Hwang, T., L. E. Band, J. M. Vose, and C. Tague. 2012. Ecosystem processes at the watershed scale: Hydrologic vegetation gradient as an indicator for lateral hydrologic connectivity of headwater catchments. Water Resour. Res. 48:W06514.

Hwang, T., K. L. Martin, J. M. Vose, D. Wear, B. Miles, Y. Kim, and L. E. Band. 2018. NonStationary Hydrologic Behavior in Forested Watersheds is Mediated by Climate-Induced Changes in Growing Season Length and Subsequent Vegetation Growth. Water Resources Research.

Idso, S., and A. Brazel. 1984. Rising atmospheric carbon dioxide concentrations may increase streamflow. Nature 312:51.

IPCC. 2007. Climate Change 2007: The physical science basis.

J.R. Slack, A. M. L., and Jurate Maciunas Landwehr. 2006. Hydro-Climatic Data Network (HCDN): Streamflow Data Set, 1874-1988. USGS Water-Resources Investigations Report 93-4076. U.S. Geological Survey.

Jarque, C. M., and A. K. Bera. 1980. Efficient tests for normality, homoscedasticity and serial independence of regression residuals. Economics letters 6:255-259.

Jasechko, S., Z. D. Sharp, J. J. Gibson, S. J. Birks, Y. Yi, and P. J. Fawcett. 2013. Terrestrial water fluxes dominated by transpiration. Nature 496:347.

Jeong, S.-J., C. H. HO, H. J. GIM, and M. E. Brown. 2011. Phenology shifts at start vs. end of growing season in temperate vegetation over the Northern Hemisphere for the period 1982-2008. Global Change Biology 17:2385-2399.

Jones, J. 2011. Hydrologic responses to climate change: considering geographic context and alternative hypotheses. Hydrological Processes:n/a-n/a.

Jones, J. A., I. F. Creed, K. L. Hatcher, R. J. Warren, M. B. Adams, M. H. Benson, E. Boose, W. A. Brown, J. L. Campbell, A. Covich, D. W. Clow, C. N. Dahm, K. Elder, C. R. Ford, N. B. Grimm, D. L. Henshaw, K. L. Larson, E. S. Miles, K. M. Miles, S. D. Sebestyen, A. T. Spargo, A. B. Stone, J. M. Vose, and M. W. Williams. 2012. Ecosystem processes and human influences regulate streamflow response to climate change at long-term ecological research sites. BioScience 62:390-404.

Jones, J. A., and D. A. Post. 2004. Seasonal and successional streamflow response to forest cutting and regrowth in the northwest and eastern United States. Water Resources Research 40:doi: 10.1029/2003WR002952.

Jönsson, P., and L. Eklundh. 2004. TIMESAT — a program for analyzing time-series of satellite sensor data. Computers \& Geosciences 30:833-845. 
Jung, M., M. Reichstein, P. Ciais, S. I. Seneviratne, J. Sheffield, M. L. Goulden, G. Bonan, A. Cescatti, J. Chen, and R. De Jeu. 2010. Recent decline in the global land evapotranspiration trend due to limited moisture supply. Nature 467:951.

Kam, J., J. Sheffield, X. Yuan, and E. F. Wood. 2013. The influence of Atlantic tropical cyclones on drought over the eastern United States (1980-2007). Journal of Climate 26:30673086.

Karl, T. R., and R. W. Knight. 1998. Secular Trends of Precipitation Amount, Frequency, and Intensity in the United States. Bulletin of the American Meteorological Society 79:231241.

Keenan, T. F., D. Y. Hollinger, G. Bohrer, D. Dragoni, J. W. Munger, H. P. Schmid, and A. D. Richardson. 2013. Increase in forest water-use efficiency as atmospheric carbon dioxide concentrations rise. Nature 499:324.

Keenan, T. F., and A. D. Richardson. 2015. The timing of autumn senescence is affected by the timing of spring phenology: implications for predictive models. Global Change Biology 21:2634-2641.

Keim, B. D. 1996. Spatial, synoptic, and seasonal patterns of heavy rainfall in the southeastern United States. Physical Geography 17:313-328.

Keim, B. D. 1997. Preliminary analysis of the temporal patterns of heavy rainfall across the southeastern United States. The Professional Geographer 49:94-104.

Kim, J. H., T. Hwang, Y. Yang, C. L. Schaaf, E. Boose, and J. William Munger. 2018. Warming-induced earlier greenup leads to reduced stream discharge in a temperate mixed forest catchment. Journal of Geophysical Research: Biogeosciences.

Kirschbaum, M. 2004. Direct and indirect climate change effects on photosynthesis and transpiration. Plant Biology 6:242-253.

Konrad, C. E., and C. M. Fuhrmann. 2013. Climate of the southeast USA: past, present, and future. Pages 8-42 Climate of the Southeast United States. Springer.

Koster, R. D., and M. J. Suarez. 1999. A simple framework for examining the interannual variability of land surface moisture fluxes. Journal of Climate 12:1911-1917.

Krakauer, N., and I. Fung. 2008. Mapping and attribution of change in streamflow in the coterminous United States. Hydrology and Earth System Sciences 12:1111-1120.

Laseter, S. H., C. R. Ford, J. M. Vose, and L. W. Swift Jr. 2012. Long-term temperature and precipitation trends at the Coweeta Hydrologic Laboratory, Otto, North Carolina, USA. Hydrology Research 43:890-901.

Laube, J., T. H. Sparks, N. Estrella, and A. Menzel. 2014. Does humidity trigger tree phenology? Proposal for an air humidity based framework for bud development in spring. New Phytologist 202:350-355.

Lawrimore, J. H., and T. C. Peterson. 2000. Pan evaporation trends in dry and humid regions of the United States. Journal of Hydrometeorology 1:543-546.

Lebourgeois, F., J.-C. Pierrat, V. Perez, C. Piedallu, S. Cecchini, and E. Ulrich. 2010. Simulating phenological shifts in French temperate forests under two climatic change scenarios and four driving global circulation models. International Journal of Biometeorology 54:563581.

Li, D., M. Pan, Z. Cong, L. Zhang, and E. Wood. 2013. Vegetation control on water and energy balance within the Budyko framework. Water Resources Research 49:969-976. 
Li, L. J., L. Zhang, H. Wang, J. Wang, J. W. Yang, D. J. Jiang, J. Y. Li, and D. Y. Qin. 2007. Assessing the impact of climate variability and human activities on streamflow from the Wuding River basin in China. Hydrological Processes 21:3485-3491.

Liang, L., M. D. Schwartz, and S. Fei. 2012. Photographic assessment of temperate forest understory phenology in relation to springtime meteorological drivers. International Journal of Biometeorology 56:343-355.

Lins, H. F., and J. R. Slack. 1999. Streamflow trends in the United States. Geophys. Res. Lett. 26:227-230.

Ma, H., D. Yang, S. K. Tan, B. Gao, and Q. Hu. 2010. Impact of climate variability and human activity on streamflow decrease in the Miyun Reservoir catchment. Journal of Hydrology 389:317-324.

Manzoni, S., G. Vico, S. Thompson, F. Beyer, and M. Weih. 2015. Contrasting leaf phenological strategies optimize carbon gain under droughts of different duration. Advances in Water Resources 84:37-51.

Marchin, R. M., C. F. Salk, W. A. Hoffmann, and R. R. Dunn. 2015. Temperature alone does not explain phenological variation of diverse temperate plants under experimental warming. Global Change Biology 21:3138-3151.

Marquaridt, D. W. 1970. Generalized inverses, ridge regression, biased linear estimation, and nonlinear estimation. Technometrics 12:591-612.

McCune, B., J. B. Grace, and D. L. Urban. 2002. Analysis of ecological communities. MjM software design Gleneden Beach, OR.

Meinshausen, M., S. J. Smith, K. Calvin, J. S. Daniel, M. Kainuma, J.-F. Lamarque, K. Matsumoto, S. Montzka, S. Raper, and K. Riahi. 2011. The RCP greenhouse gas concentrations and their extensions from 1765 to 2300. Climatic Change 109:213.

Miller, M., and C. Weaver. 1971. Snow in Ohio. Ohio Agricultural Research and Development Center. Research Bulletin 1044.

Milly, P. 1994. Climate, interseasonal storage of soil water, and the annual water balance. Advances in Water Resources 17:19-24.

Mitchel, A. 2005. The ESRI Guide to GIS analysis, Volume 2: Spartial measurements and statistics. ESRI Guide to GIS analysis.

Morin, X., J. Roy, L. Sonié, and I. Chuine. 2010. Changes in leaf phenology of three European oak species in response to experimental climate change. New Phytologist 186:900-910.

Nearing, M., V. Jetten, C. Baffaut, O. Cerdan, A. Couturier, M. Hernandez, Y. Le Bissonnais, M. Nichols, J. Nunes, and C. Renschler. 2005. Modeling response of soil erosion and runoff to changes in precipitation and cover. Catena 61:131-154.

Nelson, E. A., and R. E. Dickson. 1981. Accumulation of food reserves in cottonwood stems during dormancy induction. Canadian Journal of Forest Research 11:145-154.

Neumann, J. E., J. Price, P. Chinowsky, L. Wright, L. Ludwig, R. Streeter, R. Jones, J. B. Smith, W. Perkins, and L. Jantarasami. 2015. Climate change risks to US infrastructure: impacts on roads, bridges, coastal development, and urban drainage. Climatic Change 131:97109.

Oliver, M. A., and R. Webster. 1990. Kriging: a method of interpolation for geographical information systems. International Journal of Geographical Information System 4:313332. 
Padrón, R. S., L. Gudmundsson, P. Greve, and S. I. Seneviratne. 2017. Large-Scale Controls of the Surface Water Balance Over Land: Insights From a Systematic Review and MetaAnalysis. Water Resources Research 53:9659-9678.

Panteli, M., and P. Mancarella. 2015. Influence of extreme weather and climate change on the resilience of power systems: Impacts and possible mitigation strategies. Electric Power Systems Research 127:259-270.

Parker, H. N., B. Willis, R. Bolster, W. Ashe, and M. Marsh. 1907. The Potomac River Basin. Water Supply and Irrigation Paper 192:297.

Patterson, L. A., B. Lutz, and M. W. Doyle. 2012. Streamflow Changes in the South Atlantic, United States During the Mid- and Late 20th Century1. JAWRA Journal of the American Water Resources Association 48:1126-1138.

Patterson, L. A., B. Lutz, and M. W. Doyle. 2013. Climate and direct human contributions to changes in mean annual streamflow in the South Atlantic, USA. Water Resources Research 49:7278-7291.

Penman, H. L. 1948. Natural evaporation from open water, bare soil and grass. Pages 120-145 in Proceedings of the Royal Society of London A: Mathematical, Physical and Engineering Sciences. The Royal Society.

Pinzon, J. E., and C. J. Tucker. 2014. A non-stationary 1981-2012 AVHRR NDVI3g time series. Remote Sensing 6:6929-6960.

Pitchford, J., C. Wu, L. Lin, J. Petty, R. Thomas, W. Veselka, D. Welsch, N. Zegre, and J. Anderson. 2011. Climate Change Effects on Hydrology and Ecology of Wetlands in the Mid-Atlantic Highlands. Wetlands:1-13.

Post, D. A., and J. A. Jones. 2001. Hydrologic regimes of forested, mountainous, headwater basins in New Hampshire, North Carolina, Oregon, and Puerto Rico. Advances in Water Resources 24:1195-1210.

Powell, E. J., and B. D. Keim. 2015. Trends in daily temperature and precipitation extremes for the southeastern United States: 1948-2012. Journal of Climate 28:1592-1612.

Prebyl, T. J. 2012. An analysis of the patterns and processes associated with spring forest phenology in a southern Appalachian landscape using remote sensing. uga.

Ratner, B. 2009. The correlation coefficient: Its values range between $+1 /-1$, or do they? Journal of targeting, measurement and analysis for marketing 17:139-142.

RCore. 2013. R: A language and environment for statistical computing.

RCore. 2014. R: A language and environment for statistical computing. R Foundation for Statistical Computing, Vienna, Austria. 2013. ISBN 3-900051-07-0.

Reidmiller, D., C. Avery, D. Easterling, K. Kunkel, K. Lewis, T. Maycock, and B. Stewart. 2017. Impacts, Risks, and Adaptation in the United States: Fourth National Climate Assessment, Volume II.

Reitz, M., W. E. Sanford, G. Senay, and J. Cazenas. 2017. Annual Estimates of Recharge, Quick-Flow Runoff, and Evapotranspiration for the Contiguous US Using Empirical Regression Equations. JAWRA Journal of the American Water Resources Association 53:961-983.

Richardson, A. D., R. S. Anderson, M. A. Arain, A. G. Barr, G. Bohrer, G. Chen, J. M. Chen, P. Ciais, K. J. Davis, and A. R. Desai. 2012. Terrestrial biosphere models need better representation of vegetation phenology: results from the North American Carbon Program Site Synthesis. Global Change Biology 18:566-584. 
Richardson, A. D., A. S. Bailey, E. G. Denny, C. W. MARTIN, and J. O'KEEFE. 2006. Phenology of a northern hardwood forest canopy. Global Change Biology 12:1174-1188.

Roderick, M. L., and G. D. Farquhar. 2011. A simple framework for relating variations in runoff to variations in climatic conditions and catchment properties. Water Resources Research 47.

Rodriguez-Iturbe, I. 2000. Ecohydrology: A hydrologic perspective of climate-soil-vegetation dynamies. Water Resources Research 36:3-9.

Roman, D., K. Novick, E. Brzostek, D. Dragoni, F. Rahman, and R. Phillips. 2015. The role of isohydric and anisohydric species in determining ecosystem-scale response to severe drought. Oecologia 179:641-654.

Rosenzweig, C., A. Iglesias, X. Yang, P. R. Epstein, and E. Chivian. 2001. Climate change and extreme weather events; implications for food production, plant diseases, and pests. Global change and human health 2:90-104.

Saino, N., D. Rubolini, E. Lehikoinen, L. V. Sokolov, A. Bonisoli-Alquati, R. Ambrosini, G. Boncoraglio, and A. P. Møller. 2009. Climate change effects on migration phenology may mismatch brood parasitic cuckoos and their hosts. Biology Letters:rsbl20090312.

Sakai, A., and W. Larcher. 2012. Frost survival of plants: responses and adaptation to freezing stress. Springer Science \& Business Media.

Sankarasubramanian, A., and R. M. Vogel. 2002. Annual hydroclimatology of the United States. Water Resources Research 38.

Sankarasubramanian, A., and R. M. Vogel. 2003. Hydroclimatology of the continental United States. Geophysical Research Letters 30.

Sankarasubramanian, A., R. M. Vogel, and J. F. Limbrunner. 2001. Climate elasticity of streamflow in the United States. Water Resources Research 37:1771-1781.

Saxe, H., M. G. Cannell, Ø. Johnsen, M. G. Ryan, and G. Vourlitis. 2001. Tree and forest functioning in response to global warming. New Phytologist 149:369-399.

Schaake, J. C. 1990. From climate to flow. Climate change and US water resources.:177-206.

Schwartz, M. D. 1997. Spring index models: an approach to connecting satellite and surface phenology. Phenology in seasonal climates I:23-38.

Schwartz, M. D., R. Ahas, and A. Aasa. 2006. Onset of spring starting earlier across the Northern Hemisphere. Global Change Biology 12:343-351.

Schwartz, M. D., B. C. Reed, and M. A. White. 2002. Assessing satellite-derived start-of-season measures in the conterminous USA. International journal of climatology 22:1793-1805.

Sen, P. K. 1968. Estimates of the regression coefficient based on Kendall's tau. Journal of the American Statistical Association 63:1379-1389.

Shen, Z., G. Fu, C. Yu, W. Sun, and X. Zhang. 2014. Relationship between the growing season maximum enhanced vegetation index and climatic factors on the Tibetan Plateau. Remote Sensing 6:6765-6789.

Siler, N., G. Roe, and D. Durran. 2013. On the dynamical causes of variability in the rainshadow effect: A case study of the Washington Cascades. Journal of Hydrometeorology 14:122-139.

Slack, J. R., and J. M. Landwehr. 1992. Hydro-climatic data network (HCDN); a US Geological Survey streamflow data set for the United States for the study of climate variations, 18741988. 2331-1258, US Geological Survey; Copies of this report can be purchased from USGS Books and Open-File Reports Section. 
Slayer, K. L. 2014. Central Appalachians: Ecoregion Description. United States Geologic Survey.

Smith, J. A., M. L. Baeck, A. A. Ntelekos, G. Villarini, and M. Steiner. 2011. Extreme rainfall and flooding from orographic thunderstorms in the central Appalachians. Water Resour. Res. 47.

Suarez, P., W. Anderson, V. Mahal, and T. Lakshmanan. 2005. Impacts of flooding and climate change on urban transportation: A systemwide performance assessment of the Boston Metro Area. Transportation Research Part D: transport and environment 10:231-244.

Szilagyi, J., G. G. Katul, and M. B. Parlange. 2001. Evapotranspiration intensifies over the conterminous United States. Journal of Water Resources Planning and Management 127:354-362.

Titus, J. S., and S. M. Kang. 1982. Nitrogen metabolism, translocation, and recycling in apple trees. Horticultural Reviews, Volume 4:204-246.

Tomer, M. D., and K. E. Schilling. 2009. A simple approach to distinguish land-use and climatechange effects on watershed hydrology. Journal of Hydrology 376:24-33.

Trenberth, K. E., L. Smith, T. Qian, A. Dai, and J. Fasullo. 2007. Estimates of the Global Water Budget and Its Annual Cycle Using Observational and Model Data. Journal of Hydrometeorology 8:758-769.

Troch, P. A., G. F. Martinez, V. R. Pauwels, M. Durcik, M. Sivapalan, C. Harman, P. D. Brooks, H. Gupta, and T. Huxman. 2009. Climate and vegetation water use efficiency at catchment scales. Hydrological Processes: An International Journal 23:2409-2414.

Tromp, J. 1969. Storage and mobilization of nitrogenous compounds in apple trees with special reference to arginine.in Long Ashton Symp, 2d, Univ of Bristol.

U.S.CensusBureau. 2009. National population estimates: Characteristics. http://www.census.gov/popest/national/asrh/NC-EST2005-asrh.html.

Vadeboncoeur, M. A., M. B. Green, H. Asbjornsen, J. L. Campbell, M. B. Adams, E. W. Boyer, D. A. Burns, I. J. Fernandez, M. J. Mitchell, and J. B. Shanley. 2018. Systematic variation in evapotranspiration trends and drivers across the Northeastern United States. Hydrological Processes 32:3547-3560.

Vicente-Serrano, S. M., S. Beguería, and J. I. López-Moreno. 2010. A multiscalar drought index sensitive to global warming: the standardized precipitation evapotranspiration index. Journal of Climate 23:1696-1718.

Vidal, M., and J. M. Amigo. 2012. Pre-processing of hyperspectral images. Essential steps before image analysis. Chemometrics and Intelligent Laboratory Systems 117:138-148.

Viviroli, D., H. H. Dürr, B. Messerli, M. Meybeck, and R. Weingartner. 2007. Mountains of the world, water towers for humanity: Typology, mapping, and global significance. Water Resources Research 43.

Viviroli, D., and R. Weingartner. 2004. The hydrological significance of mountains: from regional to global scale. Hydrology and Earth System Sciences Discussions 8:1017-1030.

Walter, M. T., D. S. Wilks, J.-Y. Parlange, and R. L. Schneider. 2004. Increasing evapotranspiration from the conterminous United States. Journal of Hydrometeorology 5:405-408.

Wang, D., and M. Hejazi. 2011. Quantifying the relative contribution of the climate and direct human impacts on mean annual streamflow in the contiguous United States. Water Resources Research 47. 
Wang, X. 2014. Advances in separating effects of climate variability and human activity on stream discharge: An overview. Advances in Water Resources 71:209-218.

Ward, D. M. 2013. The effect of weather on grid systems and the reliability of electricity supply. Climatic Change 121:103-113.

Warren, J. M., E. Pötzelsberger, S. D. Wullschleger, P. E. Thornton, H. Hasenauer, and R. J. Norby. 2011. Ecohydrologic impact of reduced stomatal conductance in forests exposed to elevated CO2. Ecohydrology 4:196-210.

White, M., S. Running, and P. Thornton. 1999. The impact of growing-season length variability on carbon assimilation and evapotranspiration over 88 years in the eastern US deciduous forest. International Journal of Biometeorology 42:139-145.

White, M. A., D. BEURS, M. Kirsten, K. DIDAN, D. W. INOUYE, A. D. RICHARDSON, O. P. JENSEN, J. O'KEEFE, G. ZHANG, and R. R. NEMANI. 2009. Intercomparison, interpretation, and assessment of spring phenology in North America estimated from remote sensing for 1982-2006. Global Change Biology 15:2335-2359.

Whitehead, P., R. Wilby, R. Battarbee, M. Kernan, and A. J. Wade. 2009. A review of the potential impacts of climate change on surface water quality. Hydrological Sciences Journal 54:101-123.

Wilbanks, T., V. Bhatt, D. Bilello, S. Bull, J. Ekmann, W. Horak, Y. J. Huang, M. D. Levine, M. J. Sale, and D. Schmalzer. 2008. Effects of climate change on energy production and use in the United States. US Department of Energy Publications: 12.

Will, R. E., S. M. Wilson, C. B. Zou, and T. C. Hennessey. 2013. Increased vapor pressure deficit due to higher temperature leads to greater transpiration and faster mortality during drought for tree seedlings common to the forest-grassland ecotone. New Phytologist 200:366-374.

Williams, L. E., and P. Baeza. 2007. Relationships among ambient temperature and vapor pressure deficit and leaf and stem water potentials of fully irrigated, field-grown grapevines. American Journal of Enology and Viticulture 58:173-181.

Wolfe, D. W., M. D. Schwartz, A. N. Lakso, Y. Otsuki, R. M. Pool, and N. J. Shaulis. 2005. Climate change and shifts in spring phenology of three horticultural woody perennials in northeastern USA. International Journal of Biometeorology 49:303-309.

Wolkovich, E. M., B. I. Cook, J. M. Allen, T. M. Crimmins, J. L. Betancourt, S. E. Travers, S. Pau, J. Regetz, T. J. Davies, and N. J. Kraft. 2012. Warming experiments underpredict plant phenological responses to climate change. Nature 485:494.

Wright, L., P. Chinowsky, K. Strzepek, R. Jones, R. Streeter, J. B. Smith, J.-M. Mayotte, A. Powell, L. Jantarasami, and W. Perkins. 2012. Estimated effects of climate change on flood vulnerability of US bridges. Mitigation and Adaptation Strategies for Global Change 17:939-955.

Wu, J., C. Miao, X. Zhang, T. Yang, and Q. Duan. 2017. Detecting the quantitative hydrological response to changes in climate and human activities. Science of The Total Environment 586:328-337.

Wu, W., J. S. Clark, and J. M. Vose. 2012. Response of hydrology to climate change in the southern Appalachian Mountains using Bayesian inferences. Hydrological Processes:n/a$\mathrm{n} / \mathrm{a}$.

Wu, W., J. S. Clark, and J. M. Vose. 2014. Response of hydrology to climate change in the southern Appalachian Mountains using Bayesian inference. Hydrological Processes 28:1616-1626. 
Xu, X., W. Liu, B. R. Scanlon, L. Zhang, and M. Pan. 2013. Local and global factors controlling water-energy balances within the Budyko framework. Geophysical Research Letters:2013GL058324.

Yue, S., P. Pilon, and G. Cavadias. 2002. Power of the Mann-Kendall and Spearman's rho tests for detecting monotonic trends in hydrological series. Journal of Hydrology 259:254-271.

Zegre, N. P., A. J. Miller, A. Maxwell, and S. J. Lamont. 2014. Multiscale Analysis of Hydrology in a Mountaintop Mine-Impacted Watershed. JAWRA Journal of the American Water Resources Association 50:1257-1272.

Zeng, S., J. Xia, and H. Du. 2014. Separating the effects of climate change and human activities on runoff over different time scales in the Zhang River basin. Stochastic Environmental Research and Risk Assessment 28:401-413.

Zeng, Z., S. Piao, X. Lin, G. Yin, S. Peng, P. Ciais, and R. B. Myneni. 2012. Global evapotranspiration over the past three decades: estimation based on the water balance equation combined with empirical models. Environmental Research Letters 7:014026.

Zhao, G., P. Tian, X. Mu, J. Jiao, F. Wang, and P. Gao. 2014. Quantifying the impact of climate variability and human activities on streamflow in the middle reaches of the Yellow River basin, China. Journal of Hydrology 519:387-398.

Zuur, A., E. Ieno, N. Walker, A. Saveliev, and G. Smith. 2009. Mixed effects models and extensions in ecology with R. Gail M, Krickeberg K, Samet JM, Tsiatis A, Wong W, editors. New York, NY: Spring Science and Business Media. 
Tables:

Table 1: Table of the 31 HCDN watersheds used to study climate and growing season changes in the central Appalachian Region. Study watershed identifiers uniquely classify USGS gauging stations used in this study and corresponds to the Identifier in Figure 1. Station number and station name refer to USGS stream gauge identifiers, and area refers to area upstream of the USGS gauge.

\begin{tabular}{|c|c|c|c|c|}
\hline \multirow[b]{2}{*}{ Identifier } & \multirow[b]{2}{*}{ Basin } & \multicolumn{2}{|l|}{ Station } & \multirow[b]{2}{*}{ Area $\left(\mathrm{km}^{2}\right)$} \\
\hline & & Number & Station Name & \\
\hline $1 \mathrm{M}$ & Monongahela & 3078000 & Casselman River at Grantsville, MD & 163 \\
\hline $2 \mathrm{M}$ & Monongahela & 3061000 & West Fork River at Enterprise, WV & 1966 \\
\hline $3 \mathrm{M}$ & Monongahela & 3075500 & Youghiogheny River near Oakland, MD & 347 \\
\hline $4 \mathrm{M}$ & Monongahela & 3080000 & Laurel Hill Creek at Ursina, PA & 313 \\
\hline $5 \mathrm{M}$ & Monongahela & 3069500 & Cheat River near Parsons, WV & 1860 \\
\hline 10 & Ohio & 3102500 & Little Shenango River at Greenville, PA & 269 \\
\hline $2 \mathrm{O}$ & Ohio & 3109500 & Little Beaver Creek near East Liverpool, OH & 1285 \\
\hline $7 \mathrm{~K}$ & Kanawha & 3175500 & Wolf Creek near Narrows, VA & 578 \\
\hline $1 \mathrm{~K}$ & Kanawha & 3180500 & Greenbrier River at Durbin, WV & 344 \\
\hline $2 \mathrm{~K}$ & Kanawha & 3186500 & Williams River at Dyer, WV & 332 \\
\hline $3 \mathrm{~K}$ & Kanawha & 3187500 & Cranberry River near Richwood, WV & 208 \\
\hline $4 \mathrm{~K}$ & Kanawha & 3198500 & Big Coal River at Ashford, WV & 1013 \\
\hline $5 \mathrm{~K}$ & Kanawha & 3179000 & Bluestone River at Durbin, WV & 1020 \\
\hline $6 \mathrm{~K}$ & Kanawha & 3183500 & Greenbrier River at Alderson, WV & 3533 \\
\hline $1 \mathrm{~T}$ & Tennessee & 348800 & North Fork Holston River near Saltsville, VA & 575 \\
\hline $2 \mathrm{~T}$ & Tennessee & 3528000 & Clinch River above Tazewell, TN & 3818 \\
\hline $3 \mathrm{~T}$ & Tennessee & 3497300 & Little River above Townsend, TN & 275 \\
\hline $4 \mathrm{~T}$ & Tennessee & 3500000 & Little Tennessee River near Pretniss, NC & 363 \\
\hline $1 \mathrm{P}$ & Potomac & 1601500 & Wills Creek near Cumberland, MD & 640 \\
\hline $2 \mathrm{P}$ & Potomac & 1610000 & Pototmac River near Great Cacapon, WV & 8052 \\
\hline $3 \mathrm{P}$ & Potomac & 1611500 & Cacapon River near Great Cacapon, WV & 1753 \\
\hline $4 \mathrm{P}$ & Potomac & 1604500 & Patterson Creek near Headsville, VS & 567 \\
\hline $5 \mathrm{P}$ & Potomac & 1643500 & Bennett Creek at Park Mills, MD & 163 \\
\hline $6 \mathrm{P}$ & Potomac & 1608500 & South Branch Potoamc River near Springfield, WV & 3810 \\
\hline 7P & Potomac & 1614500 & Conococheague Creek and Fairview, MD & 1279 \\
\hline $8 \mathrm{P}$ & Potomac & 1617800 & Marsh Run at Grimes, MD & 49 \\
\hline 9P & Potomac & 1595000 & North Branch Potomac River at Steyer, MD & 189 \\
\hline $10 \mathrm{P}$ & Potomac & 1637500 & Catoctin Creek near Middletown, MD & 173 \\
\hline $11 \mathrm{P}$ & Potomac & 1644000 & Goose Creek near Leesburg, VA & 860 \\
\hline
\end{tabular}


Table 2: Long-term historic (2000-2015) average climate and water balance components in the central Appalachian region averaged for the growing season (April to October) (Tmax; maximum temperature, Tmin [minimum temperature]; Tmean [average temperature]; $\mathrm{P}$ [Precpiation]; ET [Evapotranspiration]; DPT [Dew point temperature]; VPDmin [minimum vapor pressure deficit]; VPDmax [maximum vapor pressure deficit].

\begin{tabular}{|c|c|c|c|c|c|c|c|c|}
\hline Station Name & Tmax & Tmin & tmean & $\mathrm{P}$ & ET & $\mathrm{DPT}$ & $\mathrm{VPD}_{\min }$ & $\mathrm{VPD}_{\max }$ \\
\hline Casselman River at Grantsville, MD & 21 & 9 & 17 & 1083 & 608 & 9 & 1 & 13 \\
\hline West Fork River at Enterprise, WV & 24 & 12 & 21 & 1170 & 692 & 11 & 1 & 16 \\
\hline Youghiogheny River near Oakland, MD & 21 & 9 & 17 & 1194 & 627 & 9 & 0 & 12 \\
\hline Laurel Hill Creek at Ursina, PA & 22 & 10 & 19 & 1221 & 648 & 10 & 1 & 14 \\
\hline Cheat River near Parsons, WV & 22 & 10 & 19 & 1276 & 670 & 10 & 1 & 14 \\
\hline Average Monongahela & 22 & 10 & 19 & 1189 & 649 & 10 & 1 & 14 \\
\hline Little Shenango River at Greenville, PA & 23 & 10 & 20 & 1023 & 614 & 10 & 1 & 16 \\
\hline Little Beaver Creek near East Liverpool, OH & 23 & 12 & 20 & 985 & 631 & 10 & 1 & 16 \\
\hline Average Ohio & 23 & 11 & 20 & 1004 & 622 & 10 & 1 & 16 \\
\hline Wolf Creek near Narrows, VA & 21 & 8 & 17 & 1061 & 607 & 9 & 0 & 13 \\
\hline Greenbrier River at Durbin, WV & 21 & 10 & 18 & 1376 & 665 & 9 & 1 & 13 \\
\hline Williams River at Dyer, WV & 21 & 9 & 18 & 1124 & 619 & 9 & 1 & 13 \\
\hline Cranberry River near Richwood, WV & 25 & 13 & 22 & 1067 & 740 & 12 & 1 & 17 \\
\hline Big Coal River at Ashford, WV & 23 & 12 & 20 & 1007 & 629 & 11 & 1 & 14 \\
\hline Bluestone River at Durbin, WV & 23 & 11 & 20 & 1005 & 662 & 11 & 1 & 15 \\
\hline Greenbrier River at Alderson, WV & 24 & 11 & 20 & 949 & 693 & 11 & 1 & 16 \\
\hline Average Kanahwa & 23 & 10 & 19 & 1084 & 659 & 10 & 1 & 14 \\
\hline North Fork Holston River near Saltsville, VA & 25 & 12 & 22 & 1029 & 750 & 12 & 1 & 17 \\
\hline Clinch River above Tazewell, TN & 26 & 13 & 23 & 1014 & 781 & 13 & 1 & 18 \\
\hline Little River above Townsend, TN & 26 & 14 & 23 & 975 & 781 & 13 & 1 & 19 \\
\hline Little Tennessee River near Pretniss, NC & 24 & 11 & 21 & 1196 & 773 & 12 & 1 & 15 \\
\hline Average Tennessee & 25 & 13 & 22 & 1053 & 771 & 13 & 1 & 17 \\
\hline Wills Creek near Cumberland, MD & 24 & 11 & 20 & 974 & 642 & 10 & 1 & 16 \\
\hline Pototmac River near Great Cacapon, WV & 24 & 11 & 21 & 959 & 675 & 10 & 1 & 18 \\
\hline Cacapon River near Great Cacapon, WV & 25 & 12 & 21 & 993 & 686 & 10 & 1 & 18 \\
\hline Patterson Creek near Headsville, VS & 22 & 10 & 19 & 1015 & 605 & 9 & 1 & 15 \\
\hline Bennett Creek at Park Mills, MD & 25 & 13 & 22 & 1047 & 696 & 12 & 1 & 18 \\
\hline South Branch Potoamc River near Springfield, WV & 24 & 11 & 20 & 974 & 679 & 10 & 1 & 17 \\
\hline Conococheague Creek and Fairview, MD & 24 & 12 & 21 & 987 & 690 & 11 & 1 & 17 \\
\hline Marsh Run at Grimes, MD & 25 & 12 & 22 & 988 & 698 & 11 & 1 & 18 \\
\hline North Branch Potomac River at Steyer, MD & 25 & 11 & 21 & 946 & 665 & 11 & 1 & 18 \\
\hline Catoctin Creek near Middletown, MD & 25 & 12 & 22 & 988 & 698 & 11 & 1 & 17 \\
\hline Goose Creek near Leesburg, VA & 25 & 13 & 22 & 1069 & 723 & 12 & 1 & 17 \\
\hline
\end{tabular}




\begin{tabular}{lllllllll} 
North Fork Shenandoah River at Cootes Store, VS & 24 & 10 & 20 & 980 & 692 & 10 & 1 & 17 \\
Cedar Creek near Winchester, VA & 25 & 12 & 21 & 967 & 701 & 12 & 1 & 17 \\
Avergae Potomac & 24 & 12 & 21 & 991 & 681 & 11 & 1 & 17 \\
\hline
\end{tabular}

Table 3: Relative change (\%) in climate and water balance for growing season climate variables based on a Mann Kendal test for the 31 watersheds in the central Appalachian region from 20002013.

\begin{tabular}{|c|c|c|c|c|c|c|c|c|}
\hline Station Name & $\begin{array}{l}\text { ET } \\
(\%) \\
\end{array}$ & $\begin{array}{l}\text { DPT } \\
(\%)\end{array}$ & $\begin{array}{c}\mathrm{P} \\
(\%) \\
\end{array}$ & $\begin{array}{l}\mathrm{VPD}_{\text {min }} \\
(\%) \\
\end{array}$ & $\begin{array}{c}V^{V P D_{\max }} \\
(\%) \\
\end{array}$ & $\begin{array}{l}\mathrm{T}_{\max } \\
(\%) \\
\end{array}$ & $\begin{array}{l}\mathrm{T}_{\min } \\
(\%) \\
\end{array}$ & $\begin{array}{l}T_{\text {mean }} \\
(\%)\end{array}$ \\
\hline \multicolumn{9}{|l|}{ Monongahela } \\
\hline Casselman River at Grantsville, MD & 0.9 & 0.1 & 3.3 & -10.0 & 10.2 & 0.6 & 3.9 & -0.5 \\
\hline West Fork River at Enterprise, WV & 4.5 & -3.6 & 8.8 & 42.9 & 17.0 & 21.8 & 3.0 & 0.3 \\
\hline Youghiogheny River near Oakland, MD & 0.2 & -1.2 & 3.2 & -11.2 & 22.0 & 0.6 & 0.0 & -1.5 \\
\hline Laurel Hill Creek at Ursina, PA & 2.0 & -0.7 & 11.6 & 99.1 & 15.7 & 1.2 & 2.0 & -0.6 \\
\hline Cheat River near Parsons, WV & 0.1 & -1.1 & 3.5 & 20.1 & 16.7 & 0.7 & 3.3 & -0.6 \\
\hline Average & 1.6 & -1.4 & 6.1 & 35.9 & 16.3 & 5.3 & 2.5 & -0.6 \\
\hline \multicolumn{9}{|l|}{ Ohio } \\
\hline Little Shenango River at Greenville, PA & 4.3 & -5.3 & 7.1 & 63.7 & 13.3 & 1.7 & 10.1 & 2.0 \\
\hline Little Beaver Creek near East Liverpool, OH & 1.7 & -5.0 & 1.1 & 57.6 & 16.5 & 2.8 & 4.5 & 0.6 \\
\hline Average & 3.0 & -5.1 & 4.2 & 60.1 & 14.9 & 2.2 & 7.1 & 1.3 \\
\hline \multicolumn{9}{|l|}{ Kanahwa } \\
\hline Wolf Creek near Narrows, VA & -0.7 & -3.0 & 0.9 & 3.7 & 15.5 & 1.2 & 0.3 & -1.3 \\
\hline Greenbrier River at Durbin, WV & -0.9 & -1.4 & -6.0 & 14.9 & 18.3 & 1.2 & 1.2 & -2.2 \\
\hline Williams River at Dyer, WV & 0.0 & -1.4 & -3.4 & 81.6 & 44.8 & 3.6 & 2.8 & 1.5 \\
\hline Cranberry River near Richwood, WV & 3.4 & -2.2 & 0.5 & 51.6 & 9.8 & 2.1 & 2.1 & -0.1 \\
\hline Big Coal River at Ashford, WV & 1.5 & 3.6 & 20.6 & 25.7 & 23.8 & 2.9 & 4.4 & 1.3 \\
\hline Bluestone River at Durbin, WV & 2.0 & 0.9 & $13.2^{-}$ & 41.8 & 29.9 & 4.0 & 2.4 & 1.3 \\
\hline Greenbrier River at Alderson, WV & 1.3 & 10.8 & -9.5 & -19.6 & 9.1 & 2.8 & 9.4 & 2.6 \\
\hline Average & 1.0 & 1.2 & -7.0 & 30.3 & 20.9 & 2.5 & 3.4 & 0.5 \\
\hline \multicolumn{9}{|l|}{ Tennessee } \\
\hline North Fork Holston River near Saltsville, VA & 0.3 & 4.3 & 9.0 & -7.2 & 24.9 & -10.4 & 2.1 & -1.2 \\
\hline Clinch River above Tazewell, TN & 4.0 & 2.0 & 38.3 & 21.7 & 8.7 & 0.1 & 3.9 & -1.1 \\
\hline Little River above Townsend, TN & 0.0 & 2.0 & 13.4 & 51.5 & 11.5 & -2.9 & 3.8 & -0.6 \\
\hline Little Tennessee River near Pretniss, NC & 0.4 & 0.1 & 14.2 & 35.0 & 18.7 & -1.1 & -0.2 & -3.2 \\
\hline Average & 1.2 & 2.1 & 18.6 & 25.8 & 15.7 & -3.6 & 2.5 & -1.5 \\
\hline
\end{tabular}




\begin{tabular}{|c|c|c|c|c|c|c|c|c|}
\hline Wills Creek near Cumberland, MD & 1.9 & -2.6 & 9.6 & 17.1 & 8.8 & -0.6 & 7.2 & 0.4 \\
\hline Pototmac River near Great Cacapon, WV & 0.6 & -1.3 & 0.0 & 18.1 & 7.4 & -1.1 & 7.1 & 0.3 \\
\hline Cacapon River near Great Cacapon, WV & -2.2 & -2.5 & 5.6 & 28.6 & 2.2 & -0.5 & 6.8 & 0.1 \\
\hline Patterson Creek near Headsville, VS & 1.3 & -4.2 & 9.8 & 33.8 & 16.0 & 0.5 & 5.1 & 0.1 \\
\hline Bennett Creek at Park Mills, MD & 1.1 & -0.2 & 21.1 & 28.3 & 9.4 & 0.2 & 6.0 & 0.2 \\
\hline South Branch Potoamc River near Springfield, WV & -1.7 & -2.5 & 7.1 & 31.3 & 4.6 & -2.2 & 7.0 & -0.6 \\
\hline Conococheague Creek and Fairview, MD & 0.5 & -2.4 & 6.5 & 29.8 & 5.3 & 0.5 & 6.7 & 0.3 \\
\hline Marsh Run at Grimes, MD & 1.0 & -1.2 & 8.4 & 35.2 & 10.8 & 1.0 & 8.4 & 1.2 \\
\hline North Branch Potomac River at Steyer, MD & -1.9 & -4.9 & 8.0 & 43.9 & 10.8 & -0.2 & 7.2 & 0.1 \\
\hline Catoctin Creek near Middletown, MD & 2.03 & 0.75 & 9.27 & 64.44 & 11.92 & 1.55 & 8.08 & 1.76 \\
\hline Goose Creek near Leesburg, VA & 1.18 & -3.80 & 8.21 & 88.68 & 15.47 & 0.22 & 7.52 & 1.31 \\
\hline North Fork Shenandoah River at Cootes Store, VS & 0.30 & -2.02 & 8.59 & 47.90 & 9.18 & 0.02 & 6.85 & 0.48 \\
\hline Average & 1.03 & -0.81 & 5.78 & 33.37 & 13.09 & 1.03 & 4.63 & 0.08 \\
\hline Overall Average & 1.06 & -0.91 & 5.49 & 34.73 & 14.83 & 1.14 & 4.65 & 0.06 \\
\hline
\end{tabular}


Table 4: Global correlation analysis between three climate variables (predictor variables) and evapotranspiration (response variable) based on ordinary least squares regression across the central Appalachian region. Coefficient [a] represents the direction of the regression, VIF indicates model multicollinearity, Jarque-Bera represents value clustering, $\mathrm{R}^{2}$ indicates model performance, and Moran's I indicates spatial clustering

\begin{tabular}{|c|c|c|c|c|c|c|}
\hline Variable & $\begin{array}{l}\text { Coefficient } \\
{[\mathrm{a}]}\end{array}$ & $\begin{array}{l}\mathrm{p}- \\
\text { value }\end{array}$ & $\begin{array}{l}\text { Variance } \\
\text { Inflation } \\
\text { Factor (VIF) } \\
\end{array}$ & $\begin{array}{l}\text { Jarque- } \\
\text { Bera } \\
\text { Statistic } \\
\end{array}$ & $\begin{array}{l}\text { Adjusted } \\
\mathrm{R}^{2} \\
\end{array}$ & Moran's I \\
\hline Overall Model & - & - & - & 143.36 & 0.63 & 12.31 \\
\hline VPDmin & -0.16 & $<0.001$ & 1.46 & - & - & - \\
\hline Tmin & 0.04 & $<0.001$ & 1.44 & - & - & - \\
\hline $\mathrm{P}$ & 0.001 & $<0.001$ & 1.03 & - & - & - \\
\hline
\end{tabular}

Table 5: Local correlation between six climate variables and evapotranspiration across the central Appalachian region based on a Geographically Weighted Regression (GWR).

\begin{tabular}{lrrr}
\hline Climate Variable & \multicolumn{1}{c}{ Residuals } & \multicolumn{1}{l}{ AICc } & \multicolumn{1}{c}{$\mathrm{R}^{2}$} \\
\hline \hline Vapor Pressure Deficit Max & 10.07 & -492.22 & 0.68 \\
Vapor Pressure Deficit Min & 0.77 & -1752.6 & 0.6 \\
Dew Point Temperature & 0.85 & -1708.37 & 0.56 \\
Minimum Temperature & 0.86 & -1703.66 & 0.56 \\
Precipitation & 0.98 & -1639.81 & 0.5 \\
Mean Temperature & 1 & -1633.16 & 0.49 \\
\hline
\end{tabular}




\section{FIGURES:}

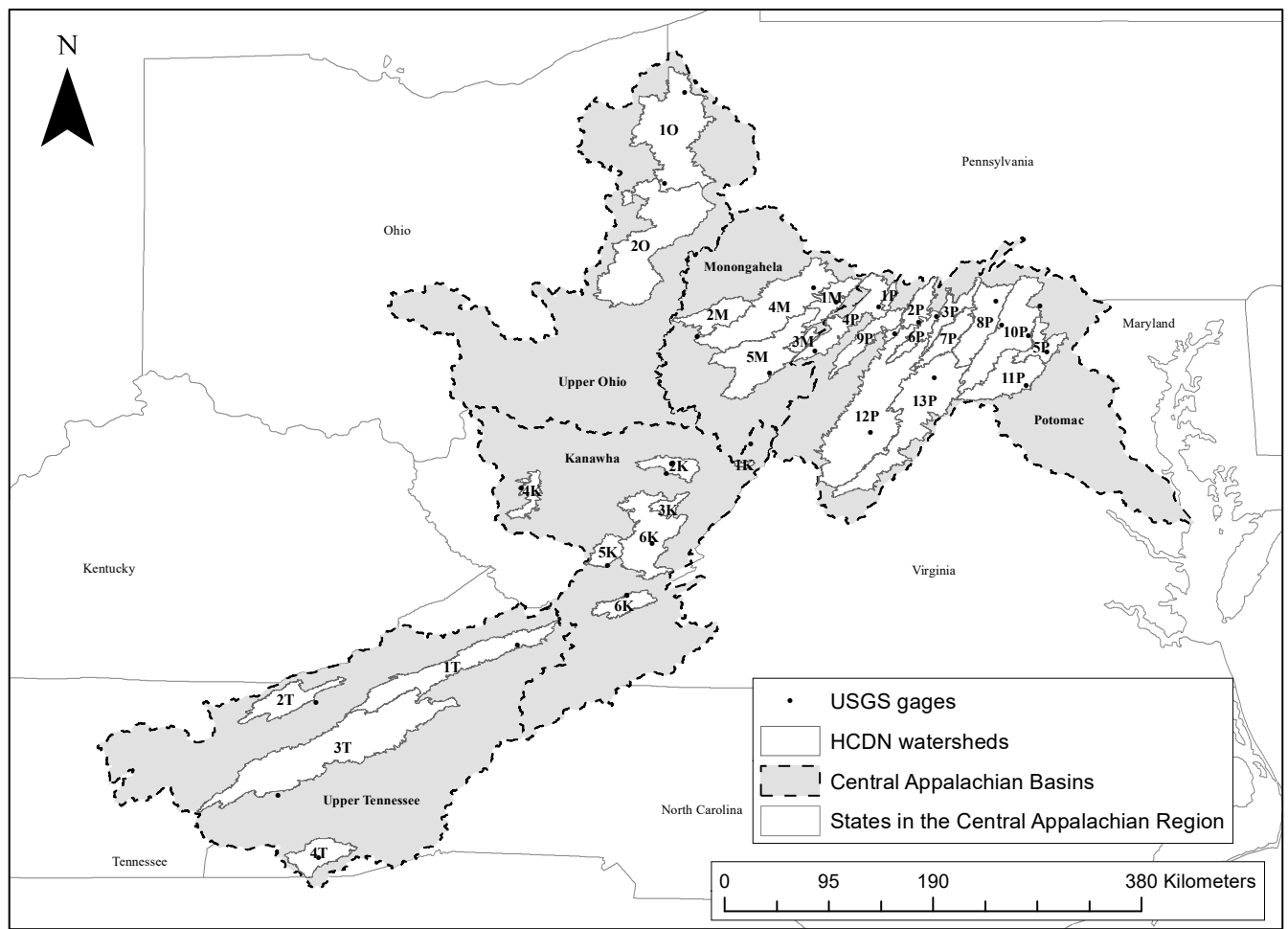

Figure 1. Location of the study basin and catchments in the central Appalachian Mountains region of the eastern USA. The dashed lines depict basin boundaries Potomac (P), Monongahela (M), Ohio (O), Kanawha (K), and Tennessee (T). The solid lines outline the 31 watersheds, and the identifiers label the basin followed by an HCDN (Slack and Landwehr 1992) watershed number from 1 to $\mathrm{n}$. 

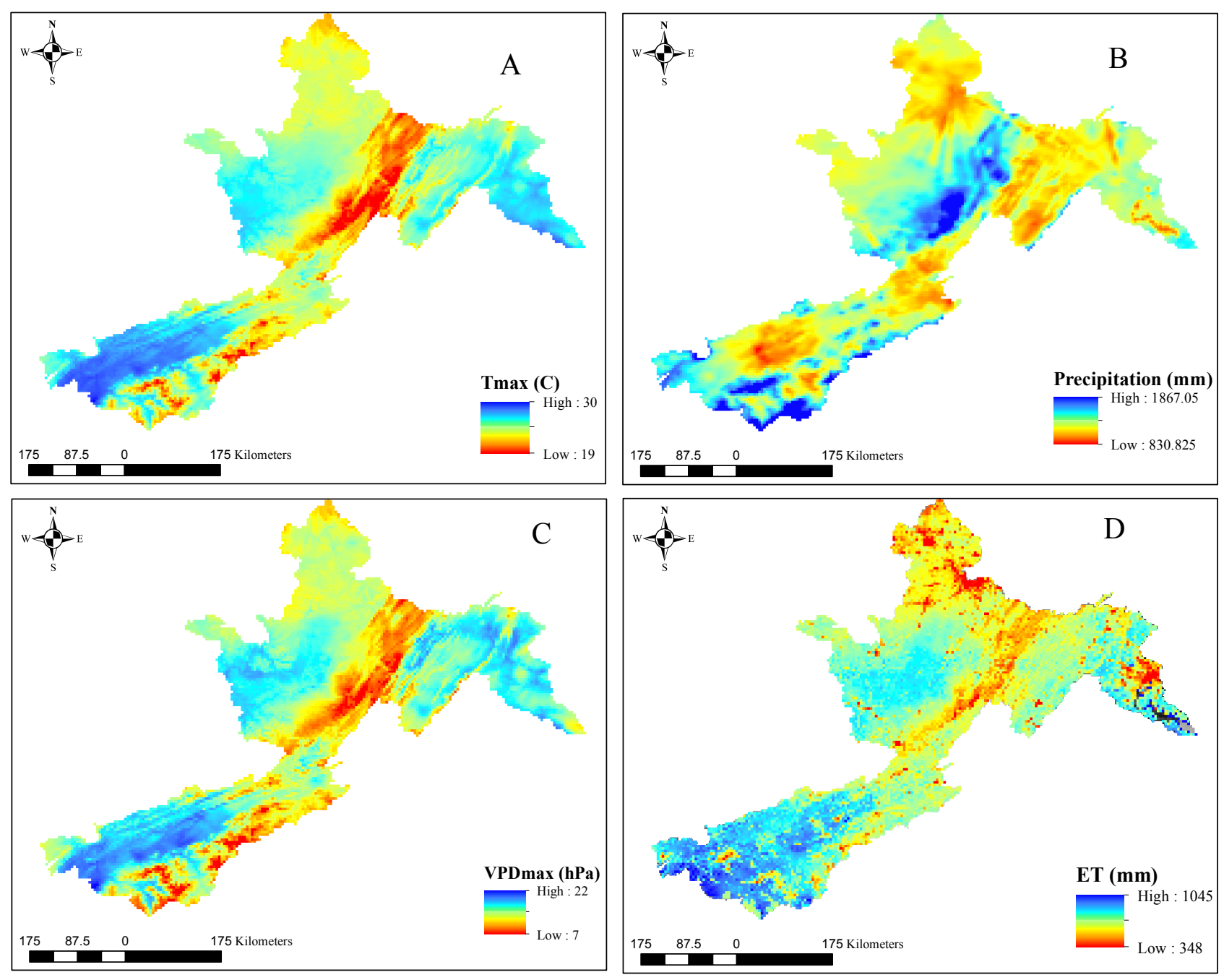

Figure 2: Map of climate variables in the central Appalachian region. A. Maximum Temperature $\left({ }^{\circ} \mathrm{C}\right)$, B. Precipitation (mm), C. Maximum Vapor Pressure Deficit (hPa), D. Evapotranspiration $(\mathrm{mm})$ 


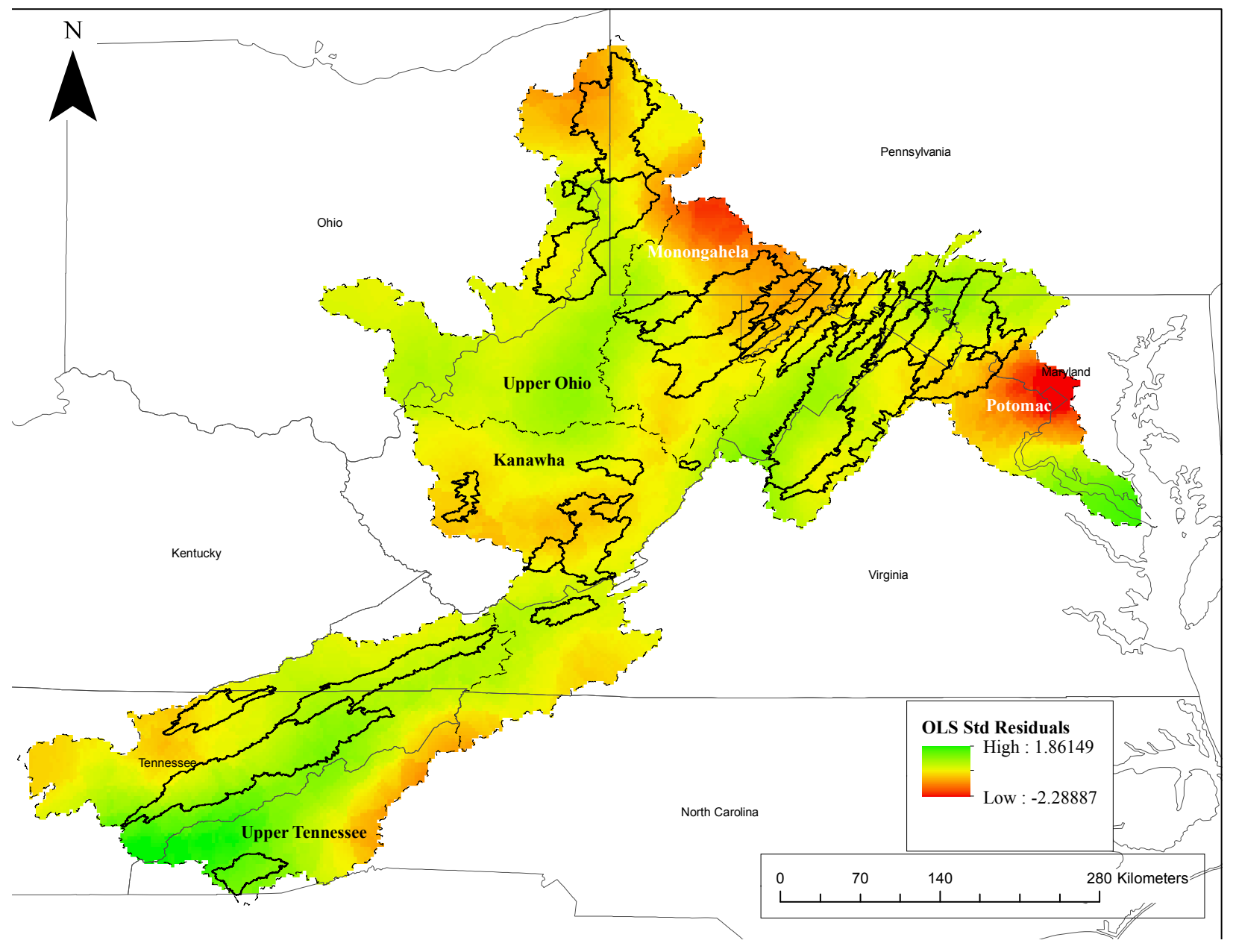

Figure 3: Standard residuals between minimum temperature, minimum vapor pressure deficit, precipitation and evapotranspiration. Residuals show clustering in the Potomac and Monongahela basins. 


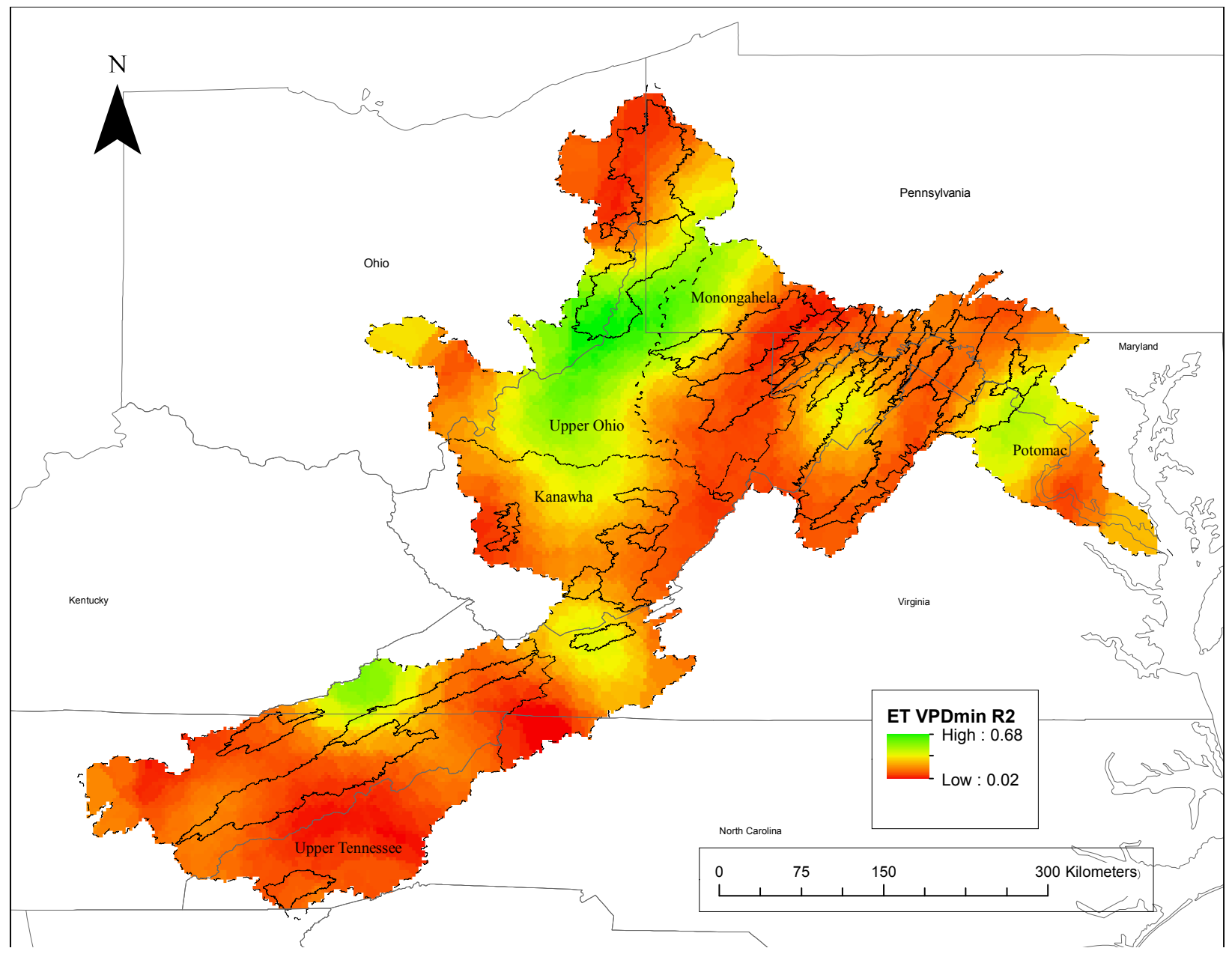

Figure 4: Local $\left(4 \mathrm{~km}^{2}\right)$ spatial regression between minimum vapor pressure deficit and evapotranspiration across the central Appalachian region using a Geographically Weighted Regression. 


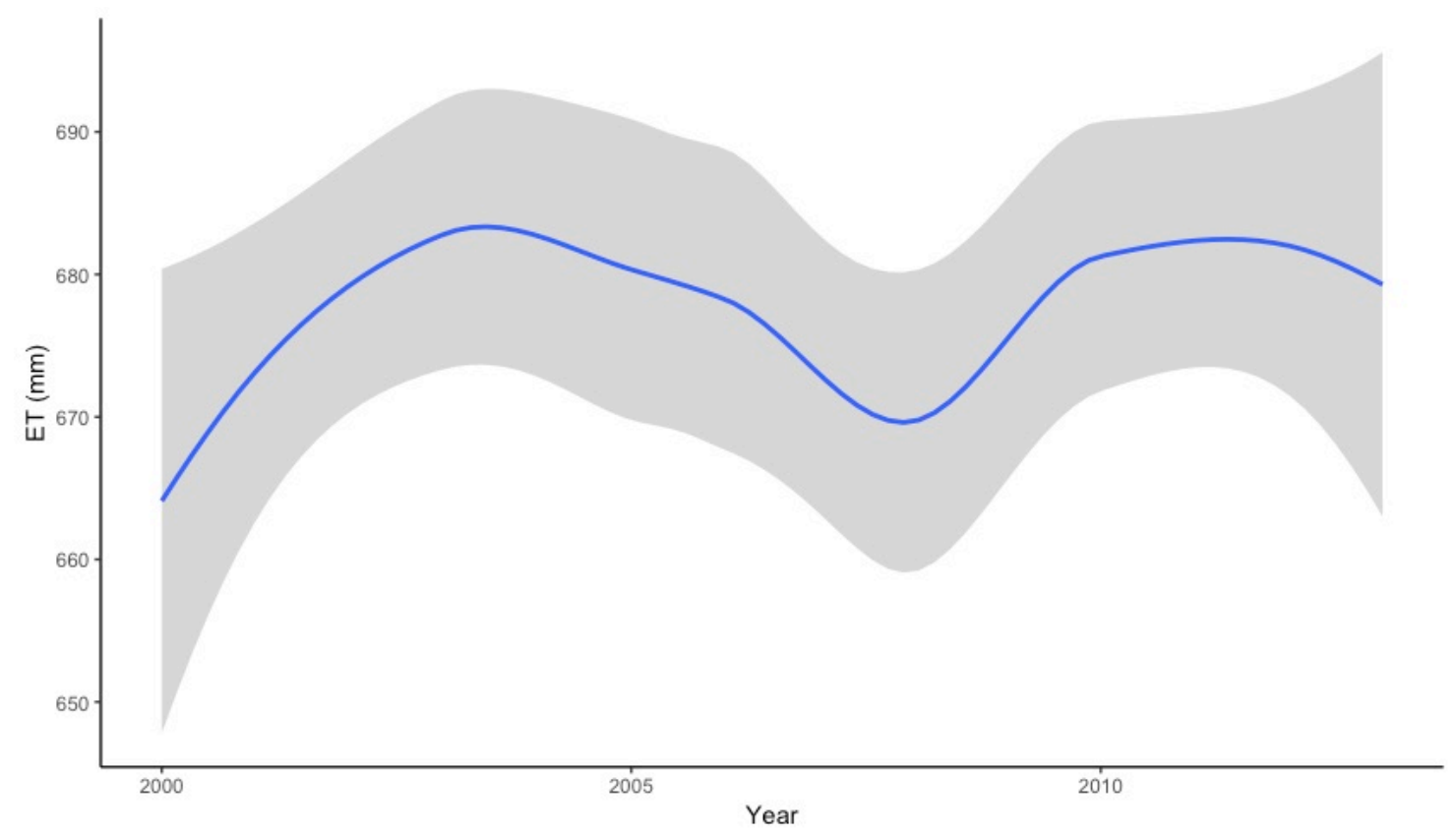

Figure 5: Smoothed time series of annual evapotranspiration from 2000-2013 using a LOESS (locally weighted scatter-plot smoother) curve. Blue line denotes the time series while the gray shaded area represents a 95\% confidence boundary. The low value in 2008 represents an extreme (D3) drought. 


\subsection{Conclusions}

This dissertation addressed three knowledge gaps 1) The impact of a longer growing season on evapotranspiration in the central Appalachian region 2) sensitivity of watershed runoff to changing climate and streamflow projections 3) local and regional evapotranspiration drivers. To address the first knowledge gap, I determined growing season length trends using AVHRR NDVI phenological data. I implemented the phenology data and 13 climate variables into two different linear mixed effects models to identify the explanatory variables for growing season length increases and to understand the relationship between growing season length at ET. I found that atmospheric vapor processes are in part responsible for the 22 day increase in growing season length, which in turn is responsible for about a $0.5 \mathrm{~mm}$ increase in ET over 30 years. These results are important for modeling future growing season length and water balance variables through the addition of an explicit atmospheric vapor-based index into current models.

To address the second knowledge gap, I implemented a Budyko-based hydrologic model to identify the sensitivity of streamflow to a $10 \%$ increase in P and PET throughout the central Appalachian region to changing climate. Sensitivity coefficients were used to estimate future streamflow for 2070-2099. The results showed that sensitivity increased with decreasing precipitation, which generally followed the rain shadow pattern of the central Appalachian region, in which sensitivity increased with increasing distance from the mountains. Future streamflow is expected to increase in all basins by between $9-17 \%$ across the region, which has important implications for infrastructure, energy supply and cost, and ecosystem services. In response to the changes, watershed management techniques could be implemented to maintain high water quality and supply standards to downstream communities.

To address the third knowledge gap, I evaluated the relationship between 6 climate variables and ET using a spatial ordinary least squares regression and a geographically weighted regression in GIS. The OLS model evaluated the regional relationship between climate variables and ET and provided information on the effects of large-scale changes in climatic variables on ET change. The GWR identified the local $\left(4 \mathrm{~km}^{2}\right)$ relationship between climate variables and ET, thereby increasing understanding of the effects of ecosystem level changes of climate on ET change. The results showed that, at the regional level, evapotranspiration is primarily explained by temperature, precipitation, and vapor pressure deficit, which underscores the importance water input and atmospheric energy in explaining terrestrial water loss. At the ecosystem level, evapotranspiration is explained by vapor pressure deficit, indicating that evapotranspiration processes at smaller scales are much more complex. ET has many competing factors in the central Appalachian region such as a longer growing season, which increases ET and ecosystem level biological drought stress mechanisms which increase water use efficiency (decrease ET). This research is important for understanding future water resources supply and implementing preventative watershed management techniques.

This dissertation ultimately provides insight into complex hydrologic processes occurring in headwater temperate forests. The central Appalachian region is an important headwater region that garners a large portion of drinking water supplies to downstream communities, though the research can be applied to any temperate headwater basins. Therefore, understanding the 
complex water loss processes occurring in the region can be used to develop watershed management methods to maintain clean and stable future drinking water resources.

\subsection{Future Directions}

Future research building on these findings should focus on the following aims:

1. Implement an explicit humidity-based growing season variable including length of season into ET and runoff models.

2. Develop future runoff using a physically based hydrologic model and evaluate how well the sensitivity projections compare to more complex model outputs

a. Using a physically based model such as the variable infiltration capacity model or the H08 model would provide a comprehensive historical and future modelled streamflow output for the region, which is currently lacking. Furthermore, comparing the streamflow output to the sensitivity projections would provide an evaluation of model error.

3. Conduct elasticity/resiliency analysis to determine how ability of the central Appalachian watershed to absorb changing climate

a. Conducting a resilience analysis would provide a more comprehensive understanding of how the watersheds respond to climate change

4. Implement more climate variables into the ET models including wind speed, wind direction, relative humidity, and solar radiation to provide a comprehensive understanding of the explanatory variable of ET

a. Implementing more climate variables including wind processes may provide more insight into large scale controls on ET 